\author{
UNIVERSIDADE DE SÃO PAULO \\ FACULDADE DE ODONTOLOGIA DE BAURU
}

CHIARA RANIERI BASSETTO

Oportunidades e desafios para o desenvolvimento econômico, tecnológico e inovativo: um estudo para implantação da pré-incubadora de projetos da Faculdade de Odontologia da Bauru - FOB - USP 


\section{Oportunidades e desafios para o desenvolvimento econômico, tecnológico e inovativo: um estudo para implantação da pré-incubadora de projetos da Faculdade de Odontologia da Bauru - FOB - USP}

Dissertação apresentada à Faculdade de Odontologia de Bauru da Universidade de São Paulo para obtenção do título de Mestre em Ciências no Programa de Ciências Odontológicas Aplicadas, na área de concentração Odontopediatria.

Orientadora: Profa. Dra. Maria Aparecida de Andrade Moreira Machado 
Bassetto, Chiara Ranieri

Oportunidades e desafios para o desenvolvimento econômico, tecnológico e inovativo: um estudo para implantação da pré-incubadora de projetos da Faculdade de Odontologia da Bauru - FOB - USP / Chiara Ranieri Bassetto. -- Bauru, 2021.

88 p. : il. ; $31 \mathrm{~cm}$.

Dissertação (mestrado) -- Faculdade de Odontologia de Bauru, Universidade de São Paulo, 2021.

Autorizo, exclusivamente para fins acadêmicos e científicos, a reprodução total ou parcial desta dissertação, por processos fotocopiadores e outros meios eletrônicos.

Assinatura:

Comitê de Ética da FOB-USP

Protocolo $\mathrm{n}^{\circ}$ : 
FOLHA DE APROVAÇÃO 


\section{DEDICATÓRIA}

Dedico essa dissertação à minha família:

Ao meu querido marido, Bassetto, que de mãos dadas me acompanhou nessa trajetória de pesquisa científica em empreendedorismo e inovação, sua grande paixão por mim compartilhada.

As minhas maravilhosas filhas, Alice e Franccesca, que com tanta pureza e simplicidade me mostram diariamente que somos seres humanos em evolução.

Aos meus pais, irmãos e avós, uma família linda que tive o privilégio de ser parte, que acredita que a escola é instituição mais transformadora da nossa sociedade, e que vive para fazer do estudar um grande prazer. 


\section{AGRADECIMENTOS}

A Deus pelos caminhos de luz que me trouxeram até aqui.

Ao meu pai “Dudu Ranieri” (in memorian), pelos ensinamentos profissionais e de vida.

A minha mãe Marli pelos exemplos e suporte incondicional em todas as fases de minha vida.

Ao meu esposo Bassetto, amor da minha vida, pelo apoio, companheirismo, orientações e colaboração na pesquisa.

Às minhas filhas Alice e Franccesca, razão da minha vida, pela compreensão da ausência ainda maior nesta fase.

Ao meu irmão Neto e minhas irmãs Giovanna e Bruna pelo carinho, atenção e alegria que nunca deixaram faltar em nossa família, mesmo em momentos de muita dificuldade que vivemos no transcorrer desse tempo de estudos e dedicação a essa pós-graduação.

A Associação Ranieri de Educação e Cultura e as Faculdades Integradas de Bauru - FIB, por acreditarem em novas ideias e ideais que juntos estamos construindo. jornada.

À amiga Susy Amantini pelo incentivo fundamental para ingresso nessa

Aos amigos que trabalham comigo nas Faculdades Integradas de Bauru FIB e na Câmara Municipal de Bauru pelo privilégio de caminharmos juntos, permitindo a necessária flexibilização das atividades profissionais desse período.

À minha orientadora, querida professora Dra. Cidinha Machado pela confiança, disponibilidade, sugestões, sorrisos e otimismo com que me acolheu e inspirou. experiências.

Aos professores e colegas da pós-graduação pelo aprendizado e troca de

À Universidade de São Paulo em especial a Faculdade de Odontologia de Bauru pela oportunidade e pela honra de tornar-me aluna da pós-graduação em Ciências Odontológicas Aplicadas, na área de concentração em Odontopediatria.

Aos programas de pós-graduação do Hospital de Anomalias Craniofaciais - HRAC-USP, da Faculdade de Economia, Administração e Contabilidade de Ribeirão Preto - FEA-RP-USP, e também da Faculdade de Arquitetura, Artes e Comunicação - FAAC-UNESP pela oportunidade de aprendizagem na condição de aluna especial.

Às pré-incubadoras participantes dessa pesquisa e ao SEBRAE, escritório regional em Bauru, na pessoa do consultor Dr. Clemilton Bassetto pelo compartilhamento das experiências essenciais para os resultados dessa dissertação. 
"Aqueles que passam por nós não vão sós, não nos deixam sós.

Deixam um pouco de si, levam um pouco de nós." 


\section{RESUMO}

A sociedade contemporânea demanda esforços cada vez maiores por parte dos gestores no sentido de encontrar melhores e mais eficientes caminhos para a promoção do desenvolvimento econômico e social. A necessidade de inovação constante e a busca permanente de novos modelos de gestão acabam por orientar as instituições que se colocam na vanguarda do seu tempo. A conjugação de forças entre diferentes atores institucionais pode oferecer melhores condições para a transformação de ideias em soluções práticas para a sociedade, no desenvolvimento de empreendedores dispostos a criar novas empresas e novas tecnologias, provocar a interação entre centros de ciência e tecnologia e empresas e, em decorrência, na geração de emprego, renda e desenvolvimento econômico e social. As pré-incubadoras de projetos podem oferecer suporte, orientação, capacitação e um caminho menos hostil para o empreendedor, permitindo a minimização de riscos e a potencialização de resultados e, desse modo, contribuir com soluções que resolvam problemas reais das pessoas e refletir em negócios estruturados com mais chance de sobrevivência no mercado. Surge, portanto, a questão central desse estudo que busca verificar se há viabilidade de implantação de um modelo de pré-incubadora na universidade e, como objetivo geral, foi de apresentar um estudo para a implantação de um modelo de pré-incubadora de empresas na área da saúde para a Faculdade de Odontologia de Bauru - FOB/USP, contribuindo com subsídios à melhor compreensão desse desafio e ao desenvolvimento e transformação de ideias em inovações. Para tanto, estruturou-se a pesquisa em três etapas: Etapa 1 pesquisa/levantamento bibliográfico envolvendo os temas em estudo - referencial teórico de apoio ao desenvolvimento da Etapa 2. Etapa 2 - Pesquisa de campo - Caracterização do universo e população pesquisada - pré-incubadoras de empresas (aplicação de questionário eletrônico e entrevista não estruturada com profissional do Sebrae com experiência em projetos de inovação). Etapa 3 - Apresentação dos resultados e discussão. Com base nas análises dos resultados obtidos, foi possível identificar a existência de viabilidade técnica para implantação da pré-incubadora de projetos da Faculdade de Odontologia da Bauru - FOB USP. Ao final, apresenta-se um Roteiro para Implantação da Pré-incubadora, destacando seus possíveis benefícios para a instituição e para os participantes do projeto, sua missão e seus objetivos, bem como a apresentação do Ciclo de Risco de Projetos e o seu Ciclo de Préincubação. Ainda, foi possível apresentar a análise das Forças, Oportunidades, Fraquezas e Ameaças (FOFA) para a sua implantação e, for fim, o Quadro Modelo de Negócios (Canvas) da pré-incubadora onde se demonstra toda a trajetória metodológica desenvolvida como contribuição às futuras aplicações em outros contextos na universidade.

Palavras-chave: Inovação. Empreendedorismo. Desenvolvimento econômico e social. 


\section{ABSTRACT \\ Opportunities and challenges for economic, technological and innovative development: a study for the implementation of the pre-incubator for projects of the Faculdade de Odontologia da Bauru - FOB - USP}

Contemporary society demands increasing efforts by managers in order to find better and more efficient ways to promote economic and social development. The need for constant innovation and the permanent search for new management models end up guiding the institutions that are at the forefront of their time. The combination of forces between different institutional actors can offer better conditions for the transformation of ideas into practical solutions for society, in the development of entrepreneurs willing to create new companies and new technologies, to provoke the interaction between science and technology centers and companies and, as a result, in the generation of jobs, income and economic and social development. Project pre-incubators can offer support, guidance, training and a less hostile path for the entrepreneur, allowing the minimization of risks and the enhancement of results and, thus, contribute with solutions that solve people's real problems and reflect on business structured with more chance of survival in the market. Therefore, the central question of this study arises, which seeks to verify whether there is a feasibility of implementing a pre-incubator model at the university and, as a general objective, was to present a study for the implementation of a pre-incubator model of companies in health area for the Faculty of Dentistry of Bauru - FOB / USP, contributing with subsidies to a better understanding of this challenge and to the development and transformation of ideas into innovations. To this end, the research was structured in three stages: Stage 1 - bibliographic research / survey of the themes under study - theoretical framework to support the development of Stage 2. Stage 2 - Field research - Characterization of the universe and researched population - pre- business incubators (application of an electronic questionnaire and unstructured interview with a Sebrae professional with experience in innovation projects). Step 3 - Presentation of results and discussion. Based on the analysis of the results obtained, it was possible to identify the existence of technical feasibility for the implementation of the pre-incubator for projects at the Faculty of Dentistry of Bauru - FOB USP. At the end, a Script for the Implementation of the Pre-incubator is presented, highlighting its possible benefits for the institution and for the project participants, its mission and objectives, as well as the presentation of the Project Risk Cycle and its Development Cycle Pre-incubation. It was also possible to present the analysis of the Strengths, Opportunities, Weaknesses and Threats (SWOT) for its implementation and, finally, the Business Model Framework (Canvas) of the Preincubator, which demonstrates the entire methodological trajectory developed as a contribution to future applications in other contexts at the university.

Keywords: Innovation. Entrepreneurship. Economic and social development. 


\section{LISTA DE ILUSTRAÇÕES}

\section{FIGURAS}

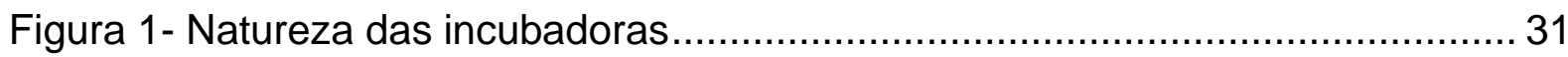

Figura 2 - Ciclo de risco de projetos pré-incubados........................................... 75

Figura 3 - Ciclo de pré-incubação de projetos …………….............................. 75

Figura 4 - Quadro Modelo de Negócios da Pré-incubadora Tecnológica FOB-USP 78

\section{GRÁFICOS}

Gráfico 1 - Distribuição das pré-incubadoras por natureza.................................... 53

Gráfico 2 - Motivos que levaram a implantação da pré-incubadora na universidade 54 Gráfico 3 - A pré-incubadora está inserida em outros projetos de empreendedorismo e inovação da universidade 55

Gráfico 4 - Principais desafios internos e externos que foram enfrentados na

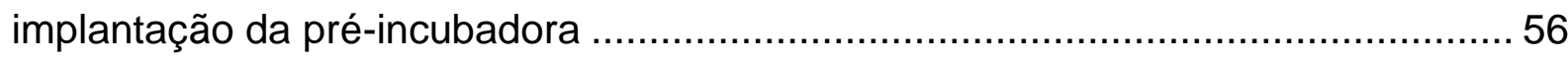

Gráfico 5 - Que tipo de apoio a pré-incubadora recebe da universidade? ............... 57

Gráfico 6 - Parceiros institucionais da pré-incubadora além da universidade........... 59 Gráfico 7 - Programas de apoio, públicos ou privados, que a pré-incubadora participa ou participou, além dos programas ofertados pela pré-incubadora 61

Gráfico 8 - Quantidade de projetos já apoiados pela pré-incubadora versus projetos que se converteram em negócios ou CNPJ

Gráfico 9 - Quantidade de projetos apoiados versus projetos que já receberam aporte financeiro de instituições financeiras, entidades de fomento, investidores ou sócio investidores

Gráfico 10 - Tempo médio de apoio dos projetos pela pré-incubadora

Gráfico 11 - Valor médio mensal cobrado por projeto apoiado pela pré-incubadora 65 Gráfico 12 - Vínculo da pré-incubadora com o empreendedor após a graduação do projeto

Gráfico 13 - Os projetos apoiados pela pré-incubadora são exclusivamente de alunos, alunos egressos, professores e funcionários da universidade

Gráfico 14 - Porcentagem de projetos com origem de pesquisas da universidade .. 68 Gráfico 15 - Apoio da pré-incubadora a projetos de outras universidades e de demais parceiros 
Gráfico 16 - Principais benefícios/serviços oferecidos aos projetos apoiados pela pré-incubadora

Gráfico 17 - Oportunidades geradas a partir da pré-incubadora para a universidade

Gráfico 18 - Há resultados positivos da pré-incubadora para o desenvolvimento econômico e social da cidade/região de atuação?

\section{QUADROS}

Quadro 1 - Tipos de inovação e definições 22

Quadro 2 - Ranking global de competitividade de países selecionados .23

Quadro 3 - Distribuição de Incubadoras de Empresas por região 30

Quadro 4 - Análise SWOT para implantação da Pré-incubadora Tecnológica FOBUSP 


\section{LISTA DE ABREVIATURA E SIGLAS}

ABStartups - Associação Brasileira de Startups

ANPEl - Associação Nacional de Pesquisa e Desenvolvimento das Empresas Inovadoras

ANPROTEC - Associação Nacional de Entidades Promotoras de Empreendimentos Inovadores

BRICS - Brasil, Rússia, Índia, China e África do Sul

CIEM - Centro Incubador de Empresas de Marília

CIETEC - Centro de Inovação, Empreendedorismo e Tecnologia

$\mathrm{CNI}$ - Confederação Nacional da Indústria

$\mathrm{CNPq}$ - Conselho Nacional de Desenvolvimento Científico e Tecnológico

FAPESP - Fundação de Amparo à Pesquisa do Estado de São Paulo

FINEP - Financiadora de Estudos e Projetos

FOB - Faculdade de Odontologia de Bauru

IEL - Incubadora de Empresas de Lins

INATEL - Instituto Nacional de Telecomunicações

INCAMP - Incubadora de Empresas de Base Tecnológica da Unicamp

IPEA - Instituto de Pesquisa Econômica Aplicada

OECD - Organisation for Economic Co-operation and Development

OMS - Organização Mundial da Saúde

PTS - Parque Tecnológico de Sorocaba

SEBRAE - Serviço Brasileiro de Apoio às Micro e Pequenas Empresas

SENAC - Serviço Nacional de Aprendizagem Comercial

SENAI - Serviço Nacional de Aprendizagem Industrial

SUS - Sistema Único de Saúde

UFPE - Universidade Federal de Pernambuco

UNIFAVIP - Centro Universitário UniFavip

UNINASSAU - Centro Universitário Maurício de Nassau

UPE - Universidade de Pernambuco

USP - Universidade de São Paulo 


\section{SUMÁRIO}

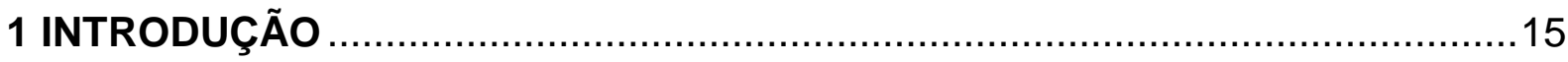

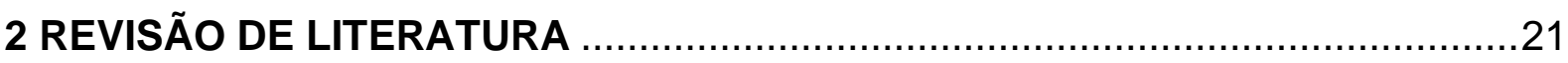

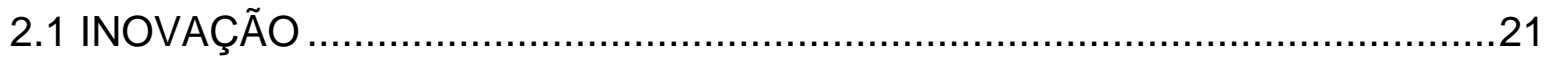

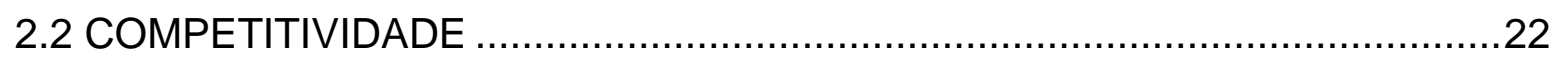

2.3 DESENVOLVIMENTO ECONÔMICO E SOCIAL ...........................................24

2.3.1 DIFERENÇA ENTRE O DESENVOLVIMENTO E CRESCIMENTO...........26

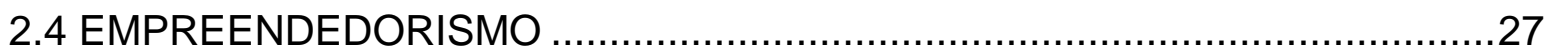

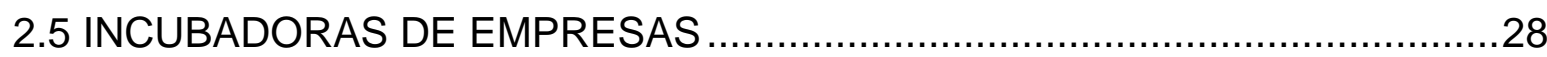

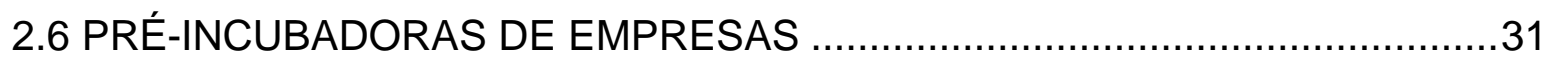

2.7 INCUBADORAS E PRÉ-INCUBADORAS EM AMBIENTES UNIVERSITÁRIOS .32

2.8 ECOSSISTEMAS DE INOVAÇÃO E EMPREENDEDORISMO ........................35

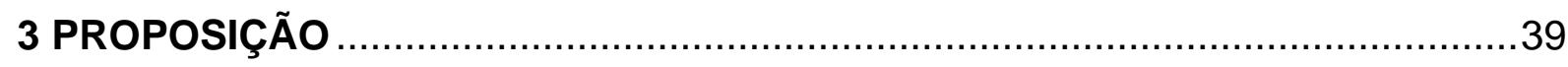

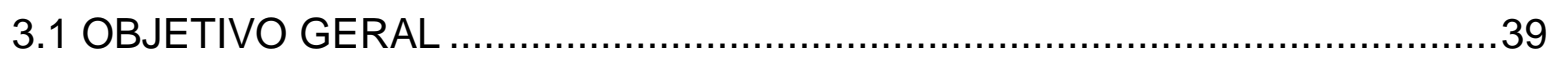

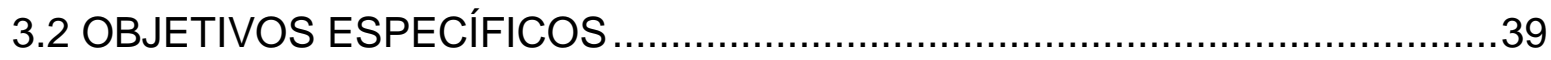

4 MÉTODOS

4.1 PESQUISA/LEVANTAMENTO BIBLIOGRÁFICO ........................................ 43

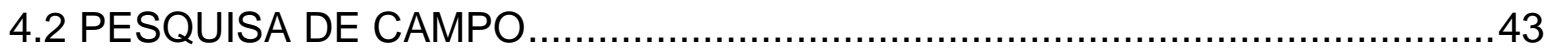

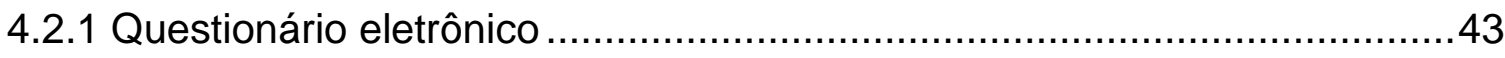

4.2.1.1 Definição do universo e população ..................................................4

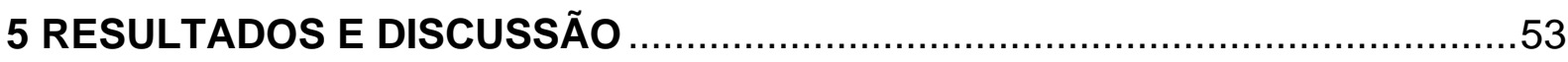

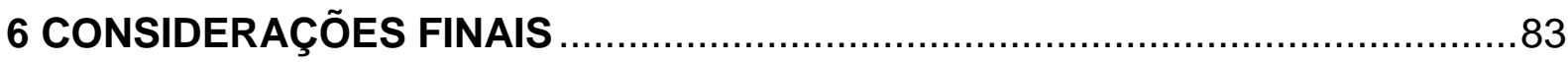

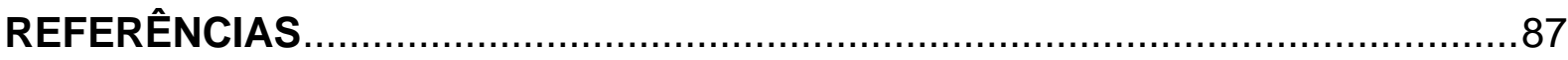




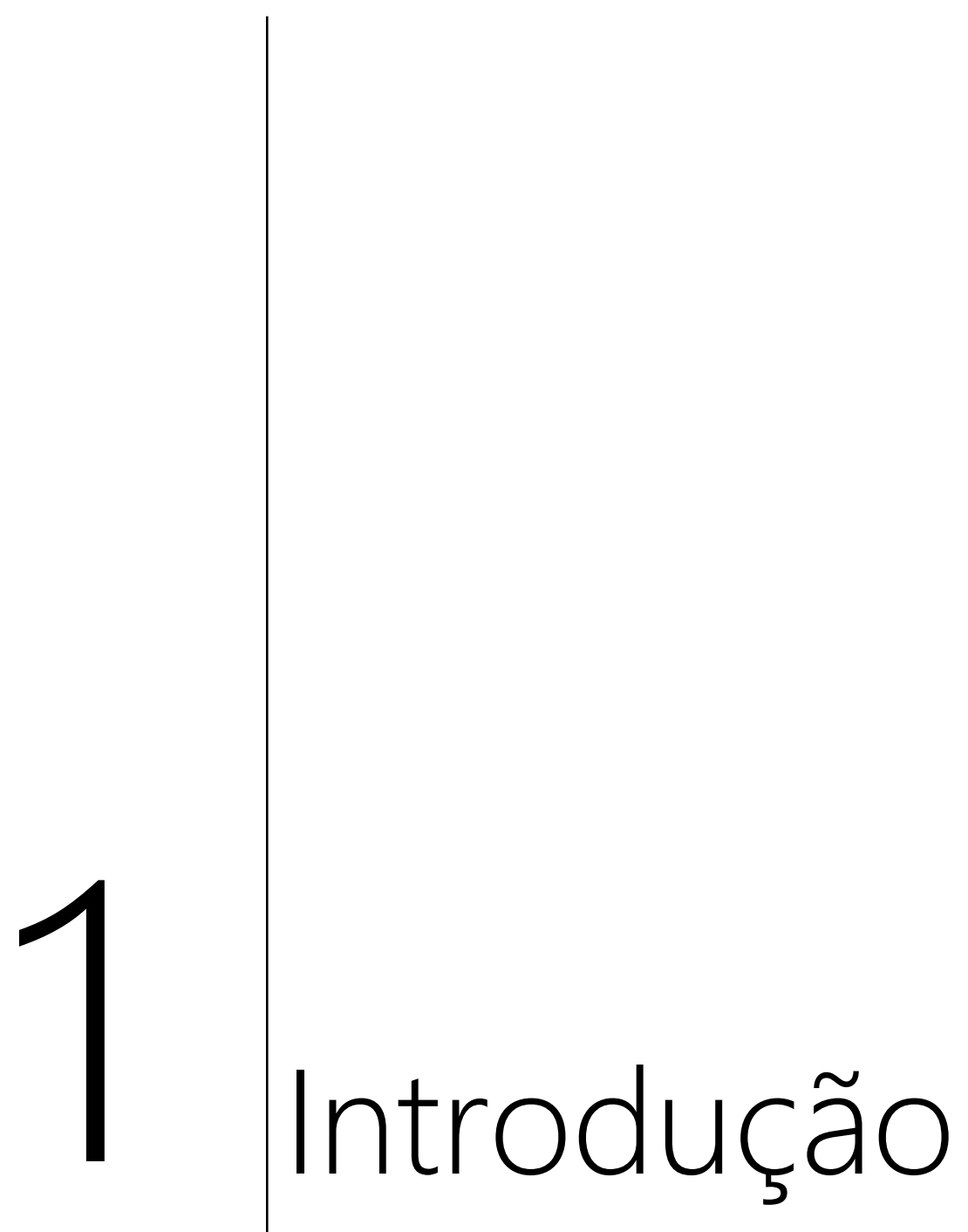






\section{INTRODUÇÃO}

Para Schumpeter (1939) o desenvolvimento econômico é conduzido pela inovação em um processo dinâmico de evolução, capaz de destruir os velhos modelos, substituindo-os por novos.

Ainda de acordo com Schumpeter (1988 apud SANTOS, FAZION e MEROE, 2011), pode-se alcançar a inovação quando há operação comercial envolvendo uma invenção, e que esta operação resulte em criação de valor. De outra forma, trata-se apenas de uma invenção, não mais que uma ideia, esboço ou modelo de algo novo, ou que possa ser melhorado, mas que não é comercializada e, portanto, não traz retornos financeiros.

Essas afirmações convergem para o entendimento de que a inovação é uma forma de promover o desenvolvimento econômico do país. Os países desenvolvidos já entenderam que por meio do desenvolvimento tecnológico é possível criar novas empresas com empregos qualificados, que desenvolvem produtos inovadores. Essas empresas têm maior chance de serem mais competitivas no mercado global. Isso gera riqueza e desenvolvimento para o país.

Mas, para que exista um ciclo virtuoso de desenvolvimento tecnológico e inovação é necessário desenvolver e fortalecer os seguintes elementos: pessoas capacitadas (talentos), centros de conhecimento com atividades de pesquisa e desenvolvimento avançados, empreendedores dispostos a criar novas empresas de base tecnológica, pesquisa e desenvolvimento nas empresas, produtos inovadores, interação entre centros de ciência e tecnologia e empresas, interação e cooperação entre empresas, atuação em redes e clusters ${ }^{1}$ organizados.

Nesse contexto, as universidades que têm como objetivos o ensino, a pesquisa e a extensão, caracterizam-se como fontes geradoras de conhecimento. A geração de conhecimento é resultado da ação da pesquisa e o ensino trabalha com a reprodução do conhecimento. No entanto, muito do que se produz de conhecimento no ambiente universitário acaba em uma estante ou biblioteca sem a aplicação prática.

\footnotetext{
1 O cluster funciona como um meio de mecanismo de reforço competitivo pela concentração geográfica, que é divido em três formas. Primeiro, ele ajuda no aumento da produtividade das empresas que constituem o cluster. Segundo, pelo grande avanço da tecnologia para melhorar o grande fortalecimento da capacidade de inovação. E, por último, pelo incentivo para a constituição de novas empresas dentro do cluster - que acaba fortalecendo as empresas a inovarem e ampliarem seus clusters.
} 
Fazendo com que o conhecimento fique restrito a um seleto grupo de pessoas e/ou instituições.

De acordo com os autores Chiarini; Vieira (2012), as universidades têm caráter vital não somente na formação de recursos humanos, mas também na geração de conhecimentos técnico-científicos para o desenvolvimento sócio-econômico no contexto dos Sistemas de Inovação. São agentes basilares e auxiliam o processo de criação e disseminação, tanto de novos conhecimentos, quanto de novas tecnologias, através de pesquisa básica, pesquisa aplicada e desenvolvimento e, por essa razão são encaradas como agentes estratégicos no contexto de uma sociedade.

Por outro lado, a sociedade carece de estudos e produção de conhecimento que possam ser aplicados e que ofereçam melhores processos, caminhos e soluções para as demandas emergentes. Segundo pesquisa da Organização Mundial da Saúde (OMS, 2015), a saúde é uma das principais preocupações do brasileiro e também um dos maiores desafios dos governantes tendo em vista a falta de recursos para financiamento do sistema único de saúde (SUS), déficit do número de profissionais, infraestrutura e equipamentos defasados, sucateados e em número insuficiente.

O modelo atual se mostrou ineficiente ao evidenciar que não adianta fazer sempre o mesmo e esperar resultados diferentes. Há a necessidade de promover uma ruptura com o modelo atual e, nesse sentido, as iniciativas de estímulo ao empreendedorismo e inovação nas Instituições de Ensino Superior se apresentam como mecanismos fundamentais para uma Política Integrada de Desenvolvimento e Inovação no Brasil. Tendo em vista que tais iniciativas têm se mostrado ao longo das últimas décadas, como excelente instrumento para promover o empreendedorismo e gerar empresas com novas tecnologias e produtos inovadores. Além disso, essas iniciativas têm o objetivo e potencial para promover a interação entre os diversos mecanismos e atores nos Ecossistemas Locais de Inovação.

Ainda, vale ressaltar as características que compõem esse Ecossistema formado por entidades que representam instituições de ensino e pesquisa, centros e grupos de pesquisa, órgãos de classe, órgãos públicos e empresas produtivas locais de iniciativa pública e privada. Entes que, atuando de modo integrado, por meio da congregação de forças podem vir a integrar um Polo Tecnológico Regional, potencializam as virtudes individuais para serem colocadas à serviço da comunidade 
e, em decorrência, promover as melhorias e prover as carências demandadas pela sociedade, por meio de novas práticas, novos modelos e novas propostas.

Destaca-se ainda, a característica universitária da cidade de Bauru, que possui 72 instituições de ensino superior credenciadas e as recentes conquistas com a implantação de dois cursos de medicina na cidade. Situações que convergem para a transformação da cidade em Polo Tecnológico Regional na área da Saúde.

Percebe-se, portanto, a necessidade do desenvolvimento desse estudo para verificar a viabilidade da implantação de um modelo de pré-incubação de projetos de saúde na Faculdade de Odontologia de Bauru, FOB-USP, considerando haver ambiente propício formado por todos os elos que podem potencializar as ações necessárias para a população, o desenvolvimento econômico e social, influenciados pela inovação e tecnologia geradas no contexto da universidade. Além disso, pretende-se avaliar a viabilidade, desenvolvimento, resultados e promover melhorias para possível replicação do modelo em outras unidades/Campi da USP e até mesmo, outras instituições de ensino superior públicas e privadas que se adequem a esse perfil de iniciativa. 


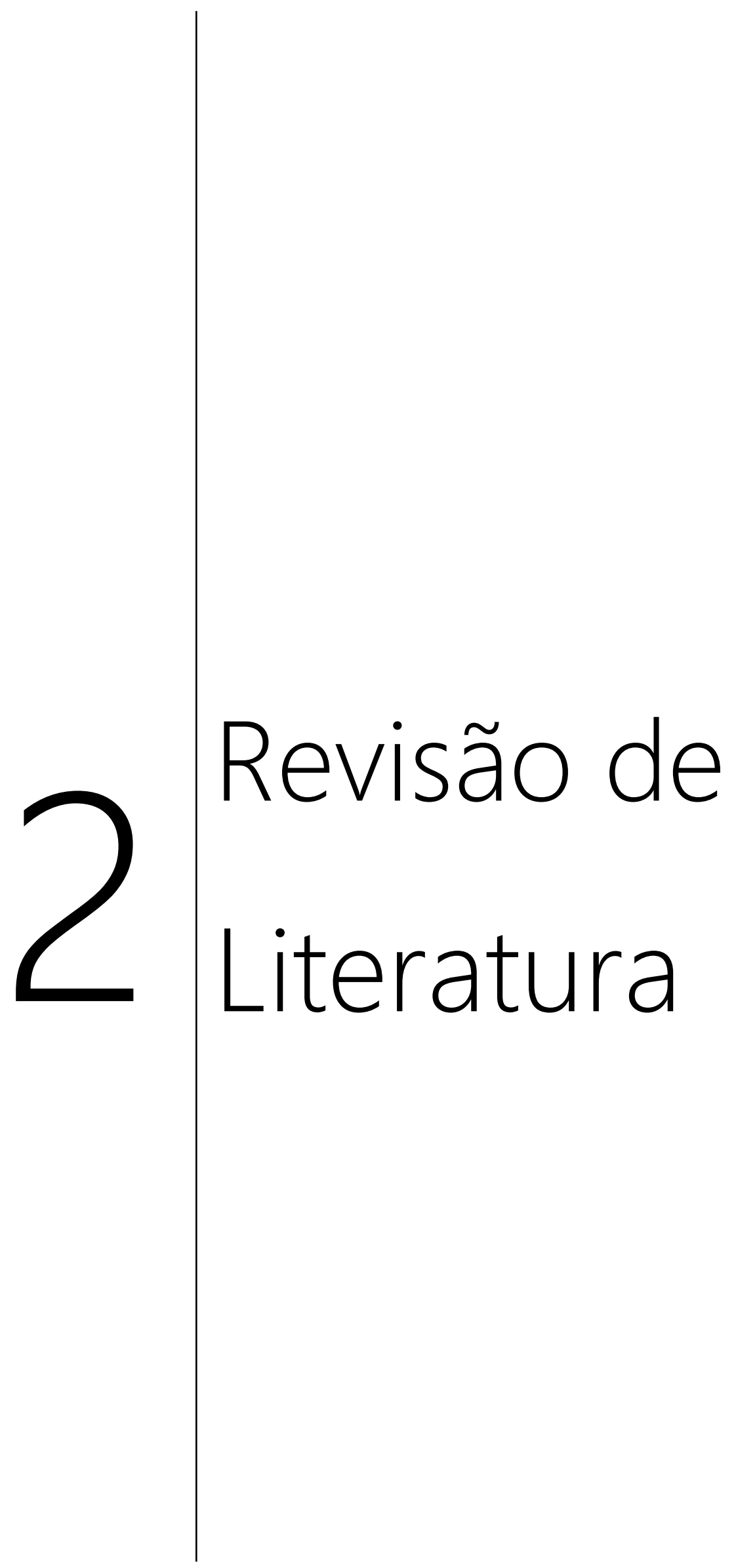





\section{REVISÃO DE LITERATURA}

\subsection{INOVAÇÃO}

Hoje em dia a palavra inovação permeia as principais discussões sobre a competitividade no mercado de consumo, na segurança, na educação, na saúde e em decorrência, no desenvolvimento econômico e social. Contudo, é necessário contextualizar o seu significado e utilização do termo no contexto desse estudo e, para tanto, recorre-se a Lei 10.973/2004, conhecida como a 'Lei da Inovação' que define inovação como a introdução de novidade ou aperfeiçoamento no ambiente produtivo ou social que resulte em novos produtos, processos ou serviços.

Para Gobbo; Vasconcellos (2008), a inovação possui três características: novidade, para a empresa, o mercado, o setor ou o mundo; concretude, sendo desenvolvida e executada; e utilidade, agregando valor percebido à empresa sob a interação do cliente. Portanto, novos produtos, processos, serviços e sistemas organizacionais apenas são considerados inovações após a comercialização no mercado ou organização, conforme Rademakers (2005). Nesse sentido, Freeman (1987) definiu quatro categorias de inovação: incremental, radical, mudanças do sistema tecnológico e mudanças no paradigma tecnoeconômico (revolução tecnológica).

O Manual de Oslo, desenvolvido pela Organização para a Cooperação e o Desenvolvimento Econômico (OECD), propõe diretrizes para coleta e interpretação de dados sobre inovação. Em sua primeira edição, tinha como foco a inovação tecnológica de produto e processo na indústria de transformação. A partir dos resultados de pesquisas realizadas por meio do instrumento, o manual passou por modificações em duas edições. Na segunda edição (1997), passou a abranger o setor de serviços, e na terceira (2005), inclui as inovações não tecnológicas.

Uma inovação é a implementação de um produto (bem ou serviço) novo ou significativamente melhorado, ou um processo, ou um novo método de marketing, ou um novo método organizacional nas práticas de negócios, na organização do local de trabalho ou nas relações externas (MANUAL DE OSLO, 2005, p.55).

O Manual de Oslo (OECD, 2005) define quatro tipos de inovações, conforme o Quadro 1. 


\section{Quadro 1 - Tipos de inovação e definições}

\begin{tabular}{|c|l|}
\hline Tipos de Inovação & \multicolumn{1}{c|}{ Definição } \\
\hline Inovação de produto & $\begin{array}{l}\text { Envolve mudanças significativas nas potencialidades de produtos e } \\
\text { serviços. Inclui bens e serviços totalmente novos e aperfeiçoamentos } \\
\text { importantes para produtos existentes }\end{array}$ \\
\hline Inovação de processo & $\begin{array}{l}\text { Representa mudanças significativas nos métodos de produção e de } \\
\text { distribuição }\end{array}$ \\
\hline Inovação & $\begin{array}{l}\text { Refere-se à implementação de novos métodos organizacionais, tais como } \\
\text { mudanças em práticas de negócios, na organização do local de trabalho } \\
\text { ou nas relações externas da empresa }\end{array}$ \\
\hline Inovação em & $\begin{array}{l}\text { Envolve a implementação de novos métodos de marketing, incluindo } \\
\text { mudanças no design do produto e na embalagem, na promoção do } \\
\text { produto e em sua colocação no mercado, e em métodos de } \\
\text { estabelecimento de preços de bens e serviços }\end{array}$ \\
\hline
\end{tabular}

Fonte: Manual de Oslo (OECD, 2005)

Tais definições permitem refletir sobre a amplitude de possibilidades ofertadas e considerando a realidade brasileira, também demonstram a complexidade do tema, em virtude da dificuldade em traduzir e incorporar tais princípios nos diferentes contextos e ambientes da sociedade.

\subsection{COMPETITIVIDADE}

Com o advento da internet, o termo competitividade tornou-se mais utilizado e frequente para traduzir os movimentos e o modelo de comportamento dos negócios com a globalização e a facilidade de acesso aos mais diferentes produtos e serviços oferecidos aos consumidores.

Soto (2005) entende que as organizações, ao estarem inseridas em um cenário em que as condições de mercado estão em constante evolução, ao definirem suas estratégias para sua manutenção no mercado, bem como a ampliação de sua base de atuação e ainda, estabelecem seus diferenciais perante os concorrentes, refletem o seu grau de competividade. 
Ainda segundo Soto (2005, p. 237), competitividade além de conferir ao consumidor, os critérios de percepção de qualidade, serviço oferecido e preço, sintetiza a capacidade das organizações em traduzir as necessidades e desejos dos clientes em melhores produtos e serviços. Além disso, define como:

[...] uma estratégia de sobrevivência empresarial para o médio e longo prazos, que se fundamenta em dez princípios e condições: 1) espírito inovador e operação de mudança; 2) fortalecimento interno da organização e trabalho em equipe; 3) conhecimento do ambiente, do mercado e das necessidades dos clientes; 4) qualidade, serviço e valor agregado; 5) novos compromissos exigência com indicadores de nível mundial e enfoque do negócio; 6) promoção do capital intelectual e emocional das organizações; 7) conhecimento e valorização dos sinais vitais da organização; 8) processo de melhoria contínua; 9) definição clara da filosofia da empresa: visão, missão e valores; 10) sabedoria dos dirigentes.

Porter (2004) entende que competitividade é a capacidade das empresas de se relacionar com o seu meio ambiente, abrangendo tanto as forças sociais como econômicas, de modo que consiga compreender e traduzir em produtos e serviços adequados ao seu mercado de atuação.

Ao analisar o documento que apresenta o Global Competitiveness Report ou Relatório Global de Competitividade (2016, 2017, 2018, 2019), elaborado pelo Fórum Econômico Mundial, é possível avaliar e comparar o desempenho do Brasil no ranking global nos últimos 4 anos:

Quadro 2 - Ranking global de competitividade de países selecionados

\begin{tabular}{|l|c|c|c|c|l|c|c|c|c|}
\hline \multicolumn{5}{|c|}{ Primeiros colocados } & \multicolumn{7}{c|}{ BRICS } \\
\hline & 2016 & 2017 & 2018 & 2019 & & 2016 & 2017 & 2018 & 2019 \\
\hline Singapura & $2^{\circ}$ & $3^{\circ}$ & $2^{\circ}$ & $1^{\circ}$ & China & $28^{\circ}$ & $28^{\circ}$ & $28^{\circ}$ & $28^{\circ}$ \\
\hline Estados Unidos & $3^{\circ}$ & $2^{\circ}$ & $1^{\circ}$ & $2^{\circ}$ & Rússia & $43^{\circ}$ & $38^{\circ}$ & $43^{\circ}$ & $43^{\circ}$ \\
\hline Hong Kong SAR & $9^{\circ}$ & $6^{\circ}$ & $7^{\circ}$ & $3^{\circ}$ & África do Sul & $47^{\circ}$ & $61^{\circ}$ & $67^{\circ}$ & $60^{\circ}$ \\
\hline Países Baixos & $4^{\circ}$ & $4^{\circ}$ & $6^{\circ}$ & $4^{\circ}$ & Índia & $39^{\circ}$ & $40^{\circ}$ & $58^{\circ}$ & $68^{\circ}$ \\
\hline Suíça & $1^{\circ}$ & $1^{\circ}$ & $4^{\circ}$ & $5^{\circ}$ & Brasil & $81^{\circ}$ & $80^{\circ}$ & $72^{\circ}$ & $71^{\circ}$ \\
\hline
\end{tabular}

Fonte: Global Competitiveness Reporte (2016, 2017, 2018, 2019)

Segundo esse mesmo relatório, em 2012, o Brasil ocupava a 48ª posição mundial e num período de 4 anos, até 2016, perdeu 33 posições, ficando atrás, por 
exemplo, dos demais países que, ao lado do Brasil, formam os BRICS² (Rússia, Índia, China e África do Sul). Apesar de iniciar o processo de recuperação dos últimos 2 anos, estabelecendo sua posição em $71^{\circ}$ no ranking, o Brasil precisa evoluir muito para melhorar seu nível de competitividade global. Pois:

[...] à medida que a capacidade de inovação cresce em economias emergentes, como China, Índia e Brasil, elas precisam fortalecer suas habilidades e mercado de trabalho para minimizar os riscos de repercussões sociais negativas. À medida que a inovação atravessa fronteiras, mesmo países com baixa capacidade de inovação precisarão de adaptabilidade de talentos, tornando os investimentos em capital humano um dos fatores mais críticos de produtividade na próxima década. (Relatório Gobal de Competitividade, 2019, p. 9, Tradução nossa ${ }^{3}$ ).

Corroborando com essa análise, o Conselho Nacional da Indústria (CNI, 2016, p. 16) defende que essa perda progressiva de competitividade nos últimos anos foi acarretada devido:

[...] a inúmeros outros fatores, como instabilidade macroeconômica, elevadas taxas de juros, aumento inflacionário, precariedade da infraestrutura, carga tributária complexa e onerosa, entre outros. Mas, no conjunto de ações exigidas para mudar esse cenário, tanto o setor público como o privado devem tratar a inovação como ponto central, para que o Brasil seja capaz de ganhar posições no mapa global (CNI, 2016, p.16).

As informações apresentadas demonstram os desafios e a complexidade que envolvem a questão da competitividade. Por outro lado, oferece também a oportunidade de se desenvolver iniciativas que promovam e fortaleçam a inovação, a competitividade e, por conseguinte, o desenvolvimento econômico e social.

\subsection{DESENVOLVIMENTO ECONÔMICO E SOCIAL}

\footnotetext{
2 A coordenação entre Brasil, Rússia, Índia e China (BRIC) iniciou-se de maneira informal em 2006, com reunião de trabalho entre os chanceleres dos quatro países à margem da Assembleia Geral das Nações Unidas. Desde então, o acrônimo, criado alguns anos antes pelo mercado financeiro, não mais se limitou a identificar quatro economias emergentes. O BRIC passou a constituir mecanismo de cooperação em áreas que tenham o potencial de gerar resultados concretos aos brasileiros e aos povos dos demais membros. Desde 2009, os Chefes de Estado e de governo do agrupamento se encontram anualmente. Em 2011, na Cúpula de Sanya, a África do Sul passou a fazer parte do agrupamento, acrescentando o "S" ao acrônimo, agora BRICS.

3 Texto original: As innovation capacity grows in emerging economies such as China, India and Brazil, they need to strengthen their skills and labour market to minimize the risks of negative social spillovers. As innovation crosses borders, even countries with low innovation capability will need talent adaptability, making human capital investments one of the most critical factors of productivity in the coming decade.
} 
A palavra desenvolvimento que significa: "fazer crescer, medrar, prosperar, exercer, aplicar, gerar, produzir, aumentar, progredir", conforme observado no Minidicionário Aurélio da Língua Portuguesa (FERREIRA, 1993, p. 175). Termos que, considerando a realidade empresarial, devem nortear as estratégias desenvolvidas para o seu crescimento. Tais termos, convertidos em ações, determinam seu posicionamento e impulsionam suas intervenções, internas e externas e, em consequência, fortalecem sua trajetória para aumentarem suas chances de sobrevivência em um mercado extremamente competitivo.

A sociedade contemporânea está inserida em um período histórico caracterizado pela hegemonia do pensamento econômico e, através desses pensamentos, o conceito de desenvolvimento tem sido relacionado e caracterizado exclusivamente pelo crescimento econômico, onde pode-se entender que existe mais crescimento econômico do que o desenvolvimento propriamente dito. Afinal, as organizações precisam acompanhar todo o crescimento e, a partir desse começar a desenvolver as informações coletadas no decorrer de determinado período para aplicar conhecimentos novos e aumentar a sua competitividade, garantindo assim, sempre informação nova e sucesso para a empresa.

Pode-se afirmar, em concordância com Franco (2000 apud PAULA, 2006), que o desenvolvimento "deve significar melhorar a vida das pessoas (desenvolvimento humano), de todas as pessoas (desenvolvimento social), das que estão vivas hoje e das que viverão no futuro (desenvolvimento sustentável)".

$\mathrm{Na}$ atualidade, a informação passa a significar a mais nova fonte de riqueza e poder. E a emergência de uma nova economia informacional global possibilitada pelo desenvolvimento de tecnologias que transformaram o mundo e a criação de redes informacionais que pode trazer muitos benefícios (OLIVEIRA, 2005, p.1).

Todas essas situações deixam as organizações com seus ambientes mais complexos e exigentes, pois devido a globalização, a sociedade vivencia diferentes etapas e ciclos que constroem informação mais atualizada, demandando melhor conhecimento para as empresas que podem e devem crescer em relação as expectativas do desenvolvimento do país.

Tudo o que foi relatado sobre desenvolvimento acima citado precisa ser discutido e elaborado juntamente com o crescimento, pois as informações precisam ser desenvolvidas e apuradas para verificarem se realmente estão sendo apropriadas 
em contextos adequados aplicados na realidade de cada organização e do mercado em que esteja inserida.

Ampliando esses conceitos, os autores Vieira; Santos (2012, p. 364) entendem que:

As políticas de desenvolvimento econômico objetivam promover a atração de investimentos acompanhados de inserção tecnológica, para aumentar a produtividade do trabalho e, consequentemente, a competitividade regional, negligenciando fatores internos, culturais e sociais que contribuem para a riqueza empresarial, mas, sobretudo, para a riqueza humana em um determinado território.

Tem-se, portanto, a importância do desenvolvimento econômico na realidade de uma comunidade e seus reflexos em uma localidade.

\subsubsection{DIFERENÇA ENTRE O DESENVOLVIMENTO E CRESCIMENTO}

Para se obter um bom desenvolvimento dentro das organizações é preciso construir uma sólida base de informação e de comunicação, não somente sobre a hierarquia de autoridade, mas desde a base até a cúpula da organização. A partir desses fatores pode-se analisar o desenvolvimento e o crescimento dentro de cada empresa, são trabalhados esses fatores para concentrar ainda mais informações gerando conhecimento para a mesma.

Em estudos mais recentes pode-se perceber que os sistemas de informação (departamentos de recursos humanos juntamente com tecnologia da informação) estão compartilhando desafios e objetivos para os funcionários, para que esses, possam interagir com outros de seus colegas, para ampliar sua base de conhecimento, agregando valor em cada etapa e em cada troca, para adquirirem conhecimentos novos ajudando no crescimento da empresa. Dessa forma, passam a representar ativos intangíveis que surgem e se desenvolvem nas organizações, objetivando o desenvolvimento de todos e, em decorrência, o sucesso da empresa e seus reflexos na sociedade.

Para que esse crescimento exista é preciso que cada empresa esteja sempre atualizada com novos equipamentos tecnológicos, que possibilitem sistemas de informação mais sofisticados para o desenvolvimento de melhores serviços ou produtos, ou ainda, novos conhecimentos ou conhecimento estratégico utilizado e aplicado para a empresa se manter no mercado. Conforme sintetiza Paula (2006, 
p.10) ao afirmar que "o desenvolvimento exige o crescimento das habilidades, conhecimentos e competências das populações, o que tem sido conceituado como capital humano".

\subsection{EMPREENDEDORISMO}

O termo empreendedor - do francês entrepreneur - significa aquele que assume riscos e começa algo novo (CHIAVENATO, 2012).

Schumpeter (1949) afirma ser "[...] aquele que destrói a origem econômica existente pela introdução de novos produtos e serviços, pela criação de novas formas de organização ou pela exploração de novos recursos e materiais" (apud DORNELAS, 2005, p.39).

Para Chiavenato (2012), o empreendedor não é somente um fundador de novas empresas ou o construtor de novos negócios. Ele é a energia da economia, a alavanca de recursos, o impulso de talentos, a dinâmica de ideias. Mais ainda: ele é quem fareja as oportunidades e precisa ser muito rápido, aproveitando as oportunidades fortuitas, antes que outros aventureiros o façam.

No entendimento de Dornelas (2005), o empreendedorismo é o envolvimento das pessoas e processos que, em conjunto, levam a transformação de ideias em oportunidades. E a perfeita implementação destas oportunidades leva à criação de negócios de sucesso.

Contribuindo com esse conceito e ampliando o seu alcance, Schumpeter (1942), defende que empreendedorismo só pode acontecer através de pessoas com habilidades técnicas para produzir, que possuam capacidade para organizar recursos financeiros, operações internas e realizar vendas.

Considerando o ambiente acadêmico, Souza et al. (2004, p.4), afirma que "desenvolver o perfil empreendedor é capacitar o aluno para que crie, conduza e implemente o processo criativo de elaborar novos planos de vida, de trabalho, de estudo, de negócios, sendo, com isso, responsável pelo seu próprio desenvolvimento e o de sua organização".

Segundo Matos e Telles (2013), ser empreendedor é basicamente ser um dos regentes econômicos e sociais do município em que atua, movimentando-a com o fluxo de dinheiro e empregos ofertados. 
Portanto, pode-se inferir que empreender é um caminho difícil e que requer muito esforço para se obter sucesso, é caminhar por meios desconhecidos embora haja muito referencial teórico acerca do assunto. Ao contrário do que muitos pensam, empreender não é a receita para o sucesso e tampouco a nova "Corrida do Ouro" que foi o grande marco da corrida ao empreendedorismo no pós-guerra. Para o SEBRAE (2019), empreender não é garantia de sucesso, embora todos que empreendem sejam merecedores. É necessário ter brio para colocar ideias em prática.

\subsection{INCUBADORAS DE EMPRESAS}

O conceito de incubadora vem daquele que se conhece nas maternidades: a incubadora é a responsável por manter o bebê vivo e auxiliar em seu crescimento ainda que ele nasça debilitado.

De acordo com a Endeavor (2020), o termo serve para definir as entidades que promovem e estimulam empreendimentos inovadores, estejam eles nascendo agora ou já operando há algum tempo.

Reforçando esse conceito, a Associação Nacional de Entidades Promotoras de Empreendimentos Inovadores (Anprotec, 2019), afirma que as incubadoras são instituições que têm o objetivo de apoiar empreendedores com ideias inovadoras a construírem empresas sustentáveis. São ofertados serviços de suporte em gestão, aperfeiçoamento do modelo de negócios e infraestrutura necessária ao desenvolvimento e consolidação da solução.

Já a Associação Brasileira de Startups (ABStartups, 2020) entende que incubadora de empresas é uma forma de estimular o empreendedorismo. Ela fortalece e prepara as pequenas empresas com o intuito de fazê-las sobreviver no mercado. É um local que abriga esses negócios, oferecendo estrutura capaz de estimular, fornecer e agilizar a transferência de resultados de pesquisa para atividades voltadas à produção, destacando os principais benefícios desse tipo de ambiente:

Disponibiliza um ambiente planejado e protegido que serve para desenvolver os empreendimentos que desejam investir em novos projetos;

- Oferece apoios gerencial e técnico com serviços de recepção, internet, telefone, secretaria, salas de reunião, ou seja, a estrutura necessária para que se possa desenvolver o negócio; 
- Possibilita parcerias e oportunidades para que o empreendedor realize seu sonhado projeto/empresa;

- Por meio da incubadora, o empresário tem um serviço de assessoria voltado às áreas de gerência, contabilidade, jurídica, gestão financeira, apuração, controle de custo e exportação; e

- O empreendedor também tem acesso a treinamentos, cursos e assinaturas de revistas e jornais para que possa estar sempre bem informado em relação ao mercado.

Ainda segundo essa entidade, as incubadoras buscam parcerias junto a empreendedores que têm ideias inovadoras. Muitos desses centros de negócios contam com laboratórios para que o empreendedor possa desenvolver o trabalho. Além disso, os empreendedores que têm interesses em comum com as universidades e faculdades são os parceiros ideais para participar do processo. Essas incubadoras apoiam microempresas, empreendedores que ainda não constituíram uma empresa e também empresas que já estão estabelecidas no mercado, mas que desejam desenvolver um produto específico e diferente.

A Endeavor (2020) ainda destaca que as incubadoras costumam receber as empresas por até três anos em sua sede e costumam cobrar uma taxa de manutenção durante todo esse período. E vale lembrar que a inovação é um dos requisitos para que uma empresa seja aceita em uma incubadora: atualmente, estimase que $98 \%$ das empresas incubadas inovam em suas atividades.

Segundo o sítio de informações do IPEA (2020), tanto no Brasil quanto no mundo, a taxa de mortalidade de uma empresa que faz parte de uma incubadora é reduzida em $20 \%$ com relação àquelas que não fazem. Fatores que evidenciam a importância desses ambientes, principalmente nos primeiros momentos da criação dos negócios. Momentos mais críticos em que são definidos os detalhes e/ou funcionamentos dos produtos e serviços, a identificação de público alvo com seu respectivo potencial e atuação e formação da carteira de clientes.

Mapeamento realizado pela Anprotec (2019), mostra que o Brasil conta com 363 incubadoras de negócios inovadores, atendendo 3.964 empresas, que geram 14.457 postos de trabalho e faturam o total de $R \$ 551$ milhões/ano. Além disso, foi possível identificar os principais resultados obtidos com esse tipo de ambiente de apoio aos empreendedores:

- Aumento da taxa de sobrevivência das empresas de pequeno porte; 
- Apoio ao desenvolvimento local e regional por meio da geração de emprego e renda;

- Otimização dos recursos alocados pelas instituições de apoio;

- Aumento da interação entre o setor empresarial e as instituições acadêmicas; e

- Retorno para os agentes que aportam recursos financeiros.

Ainda, de acordo com a Anprotec (2019) existem incubadoras em todos os estados da federação, mas as regiões Sul e Sudeste concentram 63,9\% das incubadoras existentes no Brasil, conforme pode-se evidenciar no Quadro 3.

\section{Quadro 3 - Distribuição de Incubadoras de Empresas por região}

\begin{tabular}{|c|c|}
\hline REGIÄO & $\begin{array}{c}\text { NÚMERO DE INCUBADORAS } \\
\text { IDENTIFICADAS }\end{array}$ \\
\hline Norte & 39 \\
\hline Nordeste & 61 \\
\hline Centro-Oeste & 31 \\
\hline Sudeste & 132 \\
\hline Sul & 100 \\
\hline Total & 363 \\
\hline
\end{tabular}

Fonte: Adaptado de Anprotec (2019)

O mapeamento realizado pela Anprotec (2019) identificou a natureza das mantenedoras das incubadoras existentes no país e pode-se constatar que $61 \%$ são mantidas por universidades, sendo que $43 \%$ são mantidas por universidades públicas e $18 \%$ por universidades privadas como pode ser observado na Figura 1. 
Figura 1- Natureza das incubadoras

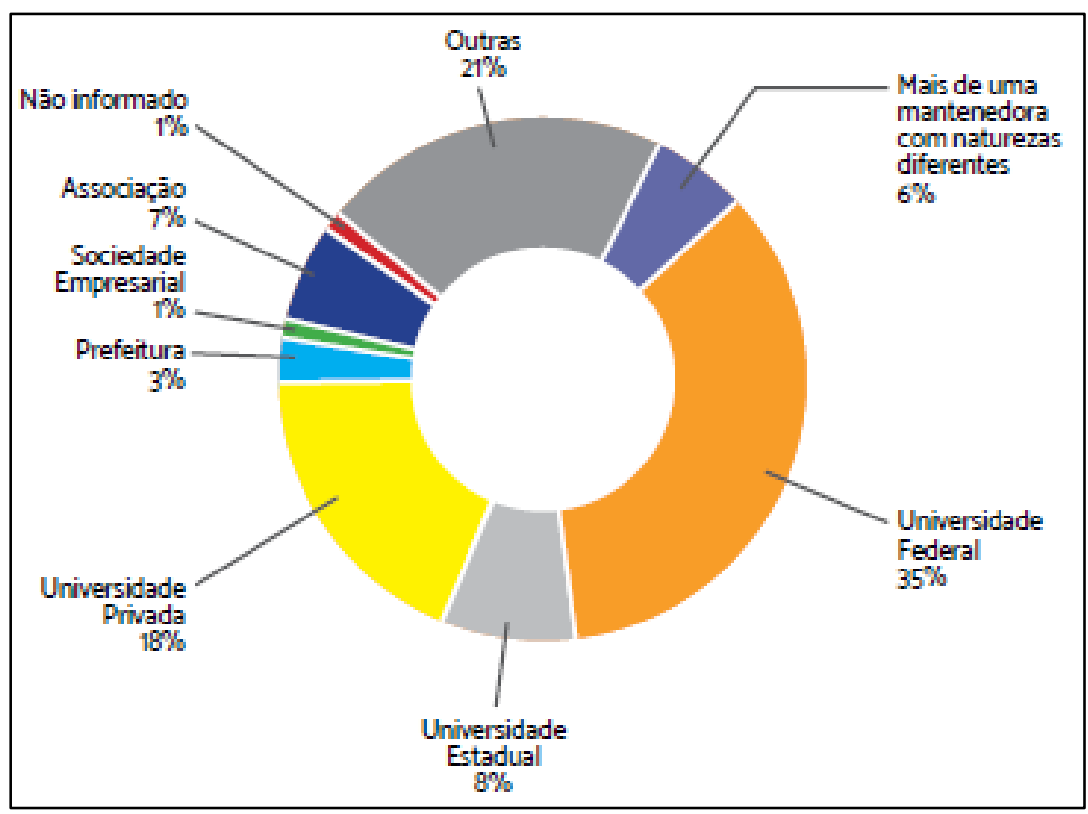

Fonte: Anprotec (2019)

A pesquisa qualitativa realizada com o mapeamento ressalta a importância das universidades apoiarem as incubadoras ao constatar que:

Na pesquisa qualitativa, esse foi um dos pontos destacados por parcela das incubadoras entrevistadas como crítico para sua operação, uma vez que a natureza da mantenedora impacta a governança, o acesso a recursos, as características da mão de obra que faz a gestão e a operação dos ambientes, e a infraestrutura física dos mecanismos (ANPROTEC, 2019, p. 21).

Com as informações demonstradas por essa importante associação de âmbito nacional é possível inferir que os negócios inovadores estão vinculados ao ambiente em que se encontram e o contexto das universidades oferece matéria prima essencial para a formação de negócios com maior chance de sucesso.

\subsection{PRÉ-INCUBADORAS DE EMPRESAS}

Como uma etapa anterior à incubadora, as pré-incubadoras apoiam projetos ainda não totalmente maduros, em busca da modelagem mais adequada para o negócio e de uma conclusão mais apurada sobre a viabilidade técnica, mercadológica e financeira do projeto/solução em desenvolvimento (INATEL, 2020).

Ainda, de acordo com a INATEL (2020), as pré-incubadoras têm a missão de contribuir com a ampliação da cultura empreendedora na comunidade acadêmica, 
esses ambientes oferecem suporte e criam condições para que ideias inovadoras se tornem oportunidades de negócio, além de preparar os alunos participantes para o mercado de trabalho, como profissionais com postura e visão empreendedoras.

A proposta principal das pré-incubadoras é identificar empreendendores em fase de validação de suas ideias, não demandando ainda estrutura substancial para o desenvolvimento do negócio e, desse modo, é possível apoiar vários projetos simultaneamente, fazendo com que seus participantes convivam em um ambiente criativo, inspirador e muito produtivo.

Segundo a Anprotec (2019), durante o período de pré-incubação, os empreendedores devem realizar algumas etapas com a finalidade de desenvolver $\mathrm{e}$ detalhar mais suas ideias e avaliarem a viabilidade técnica e econômica dos seus projetos. Podendo-se utilizar de ferramentas disponibilizadas por esses ambientes de inovação:

- Validação da Ideia e Modelagem do Negócio (CANVAS);

- Construção e Validação do MVP - Mínimo Produto Viável;

- Elaboração de um Sumário Executivo (Plano de Negócio);

- Mentorias e orientações de profissionais especializados;

- Pesquisa de Mercado;

- Visitas e Missões empreendedoras; e

- Estudos de Viabilidade.

Esses mecanismos de apoio, em conjunto com as ferramentas e métodos utilizados para o desenvolvimento dos projetos dos empreendedores, segundo a pesquisa realizada pela Anprotec (2019), aliados a oferta de estrutura adequadas, empreendedores motivados, com seus projetos instalados em ambiente colaborativo, cercados e apoiados por parcerias estratégicas, etc., oferecem maiores chances de sucesso e ainda minimizam os riscos de desenvolvimento de produtos e serviços desconectados com as necessidades do mercado.

\subsection{INCUBADORAS E PRÉ-INCUBADORAS EM AMBIENTES UNIVERSITÁRIOS}

Corroborando com os resultados da pesquisa realizada pela Anprotec (2019), autores como Frois e Parreiras (2004) defendem a necessidade e importância desses ambientes de inovação quando propiciam a interação entre a universidade, empresa e governo com a finalidade de estimularem ações que fortaleçam a cultura 
do empreendedorismo e da inovação. Também, em consonância com essas ações, existem as leis e projetos, públicos e privados, de incentivo e apoio que apontam para a necessidade de disponibilização de espaços apropriados para o desenvolvimento dessa cultura (BRESOLIN et al., 2013).

Para Botelho et al. (2014), as pré-incubadoras podem oferecer os melhores e mais eficientes caminhos que permitem estreitar as relações inerentes ao mercado, governo e universidades, e também em relação entre os empreendedores e suas conexões, entrelaçando e facilitando as interações entre os stakeholders ${ }^{4}$. Tais estruturas, condições e relacionamentos ampliam as chances de sucesso e fortalecem os negócios e, em decorrência, sua respectiva sobrevivência em um mercado competitivo.

Os indicadores apresentados em pesquisa realizada por americanos e europeus ${ }^{5}$ demonstram que a taxa de mortalidade de projetos ou empresas incubadas é de apenas $20 \%$, dado considerado como extremamente relevante se comparado com a pesquisa do Sebrae (2019) que revela que a mortalidade entre as demais empresas chega a $58 \%$. Dados dessa mesma pesquisa assustam ao revelar que $23,7 \%$ das empresas encerram suas atividades antes mesmo de completarem 2 anos de vida. Ou seja, aproximadamente 1 em cada 4 empresas constituídas fecha antes de completar 2 anos de mercado. Essas estatísticas reforçam os resultados encontrados no mapeamento realizado pela ANPROTEC (2019), demonstrando que os projetos e negócios que são apoiados por incubadoras são favorecidos por elevarem suas taxas de sobrevivência levando-os, inclusive, a se aproximar de indicadores de países desenvolvidos.

Além desses estudos e mapeamentos, Gredel et al. (2012) também indicam que as incubadoras podem potencializar as ações junto a spin-offs ${ }^{6}$ devido à falta de recursos físicos e financeiros oriundos desses tipos de projetos, aliados à incerteza no desenvolvimento tecnológico, aderência do mercado e deficiências de conhecimento empresarial, características, em geral, desse público.

\footnotetext{
${ }^{4}$ Podem ser pessoas, áreas, organizações, entidades ou todos que estão interessadas direta ou indiretamente em um projeto.

${ }^{5}$ Reportagem disponível em:

$<$ http://www.senado.gov.br/noticias/Jornal/emdiscussao/inovacao/incubadoras-de-empresas-nobrasil/incubadoras-de-empresas-processo-de-incubacao-e-programas-de-incentivo-a-inovacaotecnologica.aspx>. Acesso em 09 fev 2020.

${ }^{6}$ Smilor et al. (1990) define spin-off como um projeto ou empresa criada por um professor, funcionário ou aluno ligados a uma universidade.
} 
Oliveira (2010) ressalta que as incubadoras universitárias, a exemplo do que ocorre em outros países, como Alemanha, Estados Unidos, Israel, Itália, etc., oferecem infinitas oportunidades para a facilitação da fluência e produção do conhecimento para o setor produtivo. Esse movimento indica a transformação da universidade com essência em pesquisa para a universidade empreendedora, como consequência virtuosa desses espaços de inovação e empreendedorismo, traduzindo o conhecimento produzido em desenvolvimento econômico e social (ETZKOWITZ, 2003).

Considerando os desafios prioritários de uma instituição de ensino superior com relação à pesquisa, ensino e extensão, os espaços destinados para apoio e incentivo à inovação e ao empreendedorismo: as incubadoras, podem promover $\mathrm{e}$ facilitar ainda mais a produção de conhecimento com foco a esses desafios. Além disso, permitem que os pesquisadores, alunos e profissionais desenvolvam estudos sobre as necessidades da sociedade e dos projetos incubados, provocando um ciclo de ações com impacto direto no meio em que estão inseridas (GOERK, 2009).

As incubadoras universitárias, segundo Medeiros et al. (1992), que se dedicam a apoiar e desenvolver projetos, iniciativas e negócios de base tecnológica, tem como insumo principal o conhecimento e, considerando sua proximidade ou inserção em comunidades universitárias, o resultado dessas ações e projetos criam um diferencial para os empreendedores que podem utilizar as instalações, laboratórios e estruturas da universidade e ofertam diversos benefícios que refletem melhores produtos e serviços à sociedade.

Outro ponto de destaque, segundo o Sebrae (2019) um dos 5 maiores motivos de encerramento das atividades pelas empresas se deve a dificuldade do empreendedor em elaborar projetos e ter acesso a linhas de crédito e incentivos para a pesquisa e inovação. Fator que geralmente é potencializado pela dificuldade no acesso a universidades, pesquisadores (mestres ou doutores) ou centros de pesquisa. Tendo em vista que grande parte dos editais de subvenção e apoio condicionam os recursos e benefícios a sua conexão ou vínculo com universidades, pesquisadores e/ou profissionais responsáveis pelo desenvolvimento, acompanhamento e execução dos projetos. 


\subsection{ECOSSISTEMAS DE INOVAÇÃO E EMPREENDEDORISMO}

Não menos importantes, são os denominados ecossistemas de inovação e empreendedorismo que, segundo a ANPEI (2020) é um conjunto de condições que, em conjunto, estimulam a interação e cooperação entre diferentes atores. Parques tecnológicos, incubadoras, universidades, entidades de classe e associações são exemplos de integrantes desses ecossistemas. Tais ambientes acabam se tornando polos criativos com o objetivo de impulsionar o resultado de empresas e promover novos talentos.

Para os autores Jishnu, Gilhotra e Mishra (2011), os ecossistemas de inovação representam sistemas inter-organizacionais, políticos, econômicos, ambientais e tecnológicos da inovação e empreendedorismo, em que ocorre a catalisação, sustentação e apoio ao crescimento de negócios.

Já Wessner (2007), entende que esses ecossistemas de inovação são constituídos por conjunto de indivíduos, comunidades, organizações, recursos materiais, normas e políticas por meio de universidades, governo, institutos de pesquisa, laboratórios, pequenas e grandes empresas e os mercados financeiros numa determinada região. Todos esses atores atuam e interagem coletivamente com o objetivo de criar, amparar e agir ativamente com a fluidez de conhecimento, amparando o desenvolvimento tecnológico e gerando inovação para todos os envolvidos e que podem produzir efeitos no seu mercado de atuação.

Outra contribuição importante para definição do conceito e melhor compreensão desse termo, Papaioannou, Wield e Chataway (2007) entendem que os ecossistemas de inovação e empreendedorismo se diferenciam dos ecossistemas naturais principalmente pela presença de propósito que, em linhas gerais é o de facilitar e promover a inovação e o empreendedorismo, e ainda, pela importância da existência de uma governança que, de certo modo, pode organizar e gerenciar o sistema.

De acordo com a ANPEI (2020), existem importantes benefícios que são acarretados pelos ecossistemas de inovação e empreendedorismo e que podem influenciar positivamente o desenvolvimento de todos os seus atores envolvidos e, por conseguinte, o desenvolvimento local. Dentre esses benefícios, pode-se destacar: troca de experiências entre atores, diminuindo o tempo de desenvolvimento e pesquisa possibilitado pela ajuda mútua entre os participantes; reconhecimento da 
comunidade que, ao trabalharem em conjunto e estimular o aprendizado e a troca de informações e conhecimento, provocam o aumento da confiança e a rede de parcerias, criando um círculo virtuoso de colaboração e crescimento; melhoria das habilidades com o estímulo cada vez mais por newtworking e busca de novos conhecimentos entre os atores de modo exponencial. Tais benefícios podem ser exemplificados com a experiência vivenciada pelo Vale do Silício, na Califórnia, Estados Unidos, onde a interrelação entre diferentes entidades, empreendedores e atores provocaram, provocam e influenciam todo o ambiente em que estão inseridos. Apresentados os principais conceitos que norteiam essa dissertação, serão definidos a seguir, os objetivos gerais e específicos. 


$$
3 \begin{aligned}
& \text { Objetivo/ } \\
& \text { Proposição }
\end{aligned}
$$





\section{PROPOSIÇÃO}

\subsection{OBJETIVO GERAL}

Apresentar um estudo para a implantação de um modelo de pré-incubadora de empresas na área da saúde para a Faculdade de Odontologia de Bauru - FOBUSP.

\subsection{OBJETIVOS ESPECÍFICOS}

Identificar e selecionar junto à literatura nacional e internacional os princípios teóricos, abordagens e modelos de pré-incubadoras de empresas, inovação, competitividade, desenvolvimento econômico e social, empreendedorismo e pesquisa científica;

Realizar um levantamento e avaliar casos de sucesso e insucesso de préincubadoras universitárias;

Identificar modelos de pré-incubadoras que possam servir de referência para elaboração de modelo adequado à realidade da Faculdade de Odontologia de Bauru;

Realizar um levantamento sobre as condições para conversão de pesquisa científica em projetos e empreendimentos apoiados por pré-incubadoras;

Identificar os desafios e oportunidades com a implantação de uma préincubadora na área da saúde;

Promover a interação de pesquisadores de áreas multidisciplinares, laboratórios de pesquisas e programas de pós-graduação com o setor produtivo, no estudo e criação de produtos/processos inovadores na saúde, em especial, nas áreas de abrangência da graduação e pós-graduação da Universidade de São Paulo no município de Bauru. 



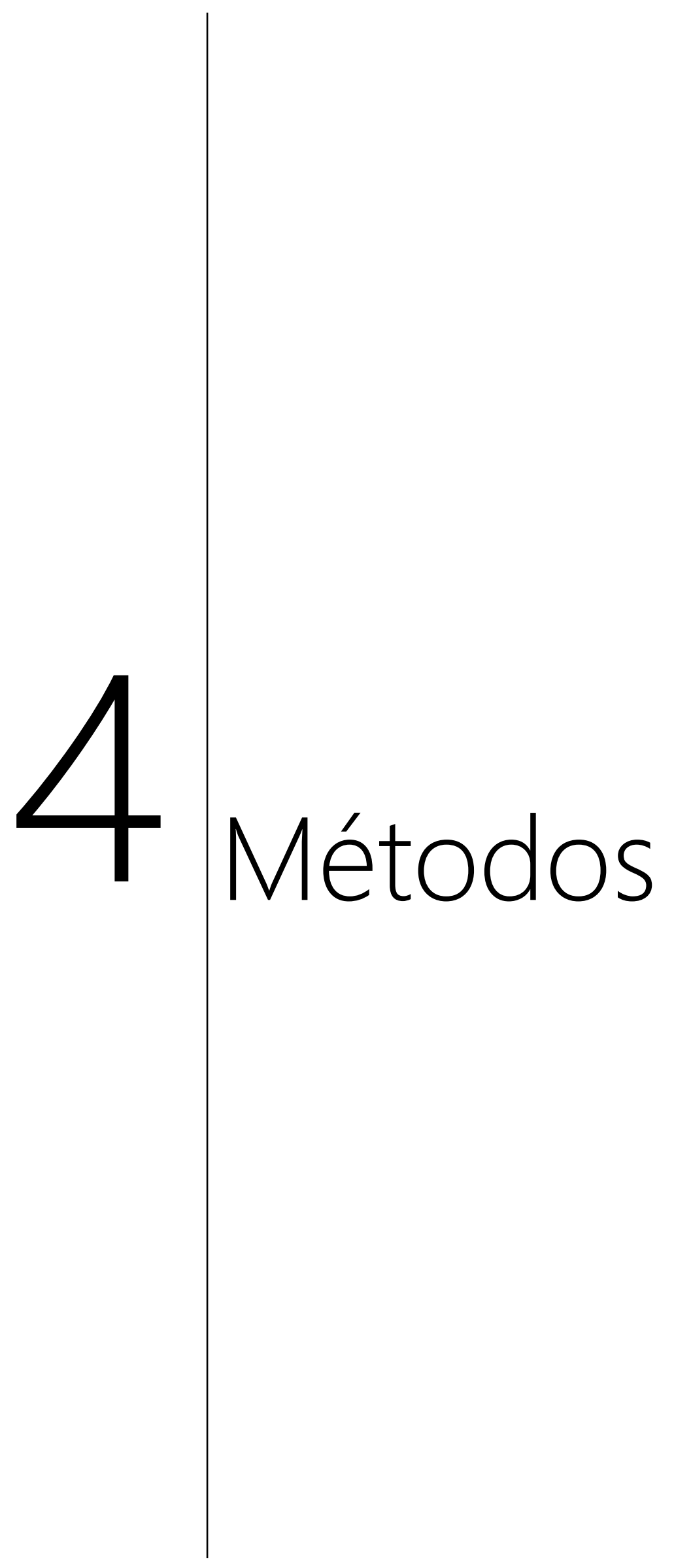





\section{MÉTODOS}

Para realização desta pesquisa, adotou-se o modelo de Vergara (2003), que combina padrões de modelo quanto aos fins e aos meios. Além disso, foram utilizados também os princípios e conceitos de Bardin (2010) e Marconi; Lakatos (2010).

Assim, quanto aos fins foi efetuada pesquisa aplicada e descritiva; quanto aos meios, desenvolveu-se um estudo bibliográfico e pesquisa de campo utilizando a técnica de questionário eletrônico.

Para realizar o procedimento em busca dos objetivos propostos, foram desenvolvidas as seguintes etapas:

\subsection{PESQUISA/LEVANTAMENTO BIBLIOGRÁFICO}

A realização desta etapa baseou-se nos princípios metodológicos de Severino (2000), Martins (2002) e Marconi; Lakatos (2010). Desse modo, essas pesquisas foram concebidas sob a abordagem de fontes nacionais e internacionais, artigos científicos, páginas de Internet de instituições representativas do segmento pesquisado e bibliotecas no sentido de encontrar os mais atuais conceitos sobre inovação, empreendedorismo, incubadoras e pré-incubadoras de empresas e suas respectivas experiências em ambientes universitários. Estes foram combinados com análises históricas que destacavam o seu reflexo no desenvolvimento econômico e social. Em especial, utilizou-se o acervo das Faculdades Integradas de Bauru e da Universidade de São Paulo - USP.

\subsection{PESQUISA DE CAMPO}

Segundo Marconi; Lakatos (2010, p.69) constitui a "[...] observação de fatos e fenômenos tal como ocorrem espontaneamente na coleta de dados e a eles referentes e no registro de variáveis que se presume relevantes para analisá-los".

Para a sua realização adotou-se o seguinte procedimento:

\subsubsection{Questionário eletrônico}


Para conseguir ampliar a conquista dos objetivos propostos, utilizou-se também para o desenvolvimento da pesquisa de campo a técnica de questionário eletrônico como instrumento de coleta de dados junto à população de interesse. Para esta pesquisa, a metodologia de questionário eletrônico foi considerada de grande valor científico porque, de acordo com Marconi; Lakatos (2010), esse instrumento desenvolvido com enfoque científico, é composto de um conjunto de perguntas ordenadas de acordo com critérios pré-estabelecidos, deve ser preenchido sem a presença do pesquisador e que tem por objetivo coletar grande quantidade dados de um grupo de respondentes.

Ainda, segundo Markoni; Lakatos (2010), para que a eficácia do questionário seja ampliada, a elaboração deve contemplar as seguintes recomendações:

- Os temas escolhidos devem estar de acordo com os objetivos da pesquisa;

- O questionário deve ser limitado em sua extensão e em sua finalidade, pois um questionário muito longo causa cansaço e desinteresse e um questionário muito curto pode não oferecer informações suficientes;

- As questões devem ser codificadas, a fim de facilitar a posterior tabulação;

- Deve estar acompanhado de orientações sobre como respondê-lo; e

- O aspecto e a estética devem ser observados.

Esses mecanismos visam oferecer condições para a execução perfeita de uma pesquisa com base metodológica e que seu resultado possa traduzir-se em respostas válidas e informações pertinentes ao estudo.

\subsubsection{Definição do universo e população}

Para o desenvolvimento da pesquisa, selecionou-se por meio de pesquisa na internet, as pré-incubadoras, preferencialmente com foco na área da saúde, instaladas em instituições de ensino superior ou com estreita parceria com as universidades.

Foi realizado um pré-teste, aplicando o questionário eletrônico com 3 préincubadoras o qual orientou no refinamento e melhoria resultante na versão final do instrumento. 
Com a versão final do questionário eletrônico, descartando as respostas obtidas com o pré-teste, inclusive com as pré-incubadoras respondentes, obteve-se a resposta de 9 (nove) pré-incubadoras, considerados como sendo uma amostra de voluntariado e acidental, porém, que tem representatividade significativa para 0 universo censitário dos sujeitos desse segmento.

Antes de realizar a pesquisa com os representantes das pré-incubadoras, no período de 20/01/2020 a 28/02/2020, efetuou-se um contato prévio com os seus gestores e/ou responsáveis, o qual permitiu discorrer sobre os objetivos e importância da pesquisa e também para encaminhar o questionário eletrônico, no meio mais adequado, para que o trabalho pudesse transcorrer do modo mais tranquilo possível.

As respostas ao questionário foram obtidas no período de 20/01/2020 a 10/03/2020.

As pré-incubadoras que responderam ao questionário eletrônico no período disponibilizado estão identificadas a seguir:

\section{Projeto: Centro Incubador de Empresas de Marília (CIEM)}

Local: Marília/SP

Início das atividades: 2017

Universidade vinculada: Centro Universitário Eurípides de Marília (Univem)

Objetivo: difundir o empreendedorismo inovador em um ambiente especialmente planejado. Apoiar ideias e projetos nascentes e inovadores por meio de serviços especializados, capacitações e consultorias que facilitem o seu desenvolvimento. Com o apoio do Centro de Inovação Tecnológica de Marília (CITec - Marília) e do Centro Universitário Eurípides de Marília (Univem), promover o fortalecimento de micro e pequenas empresas por meio da intermediação com instituições de ensino e pesquisa, órgãos governamentais e com a iniciativa privada. Disponibilizar as modalidades de apoio: pré-incubação, incubação, pós-incubação, empresa não-residente/associada e graduação.

\section{Projeto: Supera Incubadora de Empresas de Base Tecnológica}

Local: Ribeirão Preto/SP

Início das atividades: 2003

Universidade vinculada: Universidade de São Paulo

Objetivo: oferecer um ambiente de inovação para promover a transferência de conhecimento em diversos tipos de atividades. Responsável por atrair e reter empresas tecnológicas, com destaque para os setores de Saúde, Biotecnologia, 
Tecnologia da Informação e Bioenergia. O Parque surgiu do convênio entre a USP, Prefeitura Municipal de Ribeirão Preto e Secretaria de Desenvolvimento Econômico, Ciência, Tecnologia e Inovação do Estado de São Paulo.

Projeto: Incubadora de Empresas de Base Tecnológica da Unicamp (INCAMP)

Local: Campinas/SP

Início das atividades: 2015

Universidade vinculada: Universidade Estadual de Campinas (UNICAMP)

Objetivo: estimular a criação e proteger o desenvolvimento de novas empresas de base tecnológica por meio da oferta de infraestrutura e de capacitação tecnológica e gerencial para novos empreendedores em ambiente propício. Como a INCAMP está localizada dentro da Unicamp, as empresas incubadas se beneficiam da proximidade dos laboratórios e dos recursos humanos da Universidade e de um ambiente inovador, propiciado pela atuação em rede da Agência de Inovação Inova Unicamp.

\section{Projeto: Incubadora de Empresas de Lins (IEL)}

Local: Lins/SP

Início das atividades: 2003

Universidades vinculadas: Centro Universitário de Lins (Unilins) e Centro Universitário Católico Salesiano Auxilium de Lins (Unisalesiano)

Objetivo: acolher micro e pequenas empresas nascentes ou em operação, que buscam o desenvolvimento de suas atividades, agregando conhecimento, inovação e tecnologia em ambiente com estrutura para o seu desenvolvimento. A Incubadora é uma escola de empreendedorismo que visa estimular a criação e o desenvolvimento de empresas e através das orientações recebidas, os empreendedores transformam boas ideias em negócios promissores e prontos para o sucesso.

Projeto: Incubadora de Empresas de Base Tecnológica USP/IPEN Cietec

Local: São Paulo/SP

Início das atividades: 1996

Universidade vinculada: Universidade de São Paulo (USP)

Objetivo: promover o Empreendedorismo Inovador, incentivando a transformação do conhecimento em produtos e serviços de valor agregado para o 
mercado. Ao longo de seus 20 anos de existência, o Cietec desenvolveu metodologias e expertise na seleção e acompanhamento de empresas nascentes de base tecnológica, traduzidos na sistematização de processos incubação, na criação e gestão de habitats de inovação e na promoção das atividades e suporte à gestão tecnológica, de marketing e administrativa de startups.

\section{Projeto: Aceleradora Parque Tecnológico de Sorocaba (PTS)}

Local: Sorocaba/SP

Início das atividades: 2017

Universidade vinculada: Não possui vínculo formal com universidades

Objetivo: criar e/ou desenvolver startups, apoiando-as em todas as etapas da jornada empreendedora.

\section{Projeto: Incubadora Inova}

Local: Belo Horizonte/MG

Início das atividades: 2017

Universidade vinculada: Universidade Federal de Minas Gerais (UFMG)

Objetivo: estimular o empreendedorismo e apoiar empresas e projetos de base tecnológica nascentes na Universidade. $O$ trabalho da incubadora abre oportunidades para a inserção de empresas inovadoras no mercado de trabalho.

\section{Projeto: Eretz.bio}

Local: São Paulo/SP

Início das atividades: 2018

Universidade vinculada: Universidade Einstein (IEEP) - Sociedade Beneficente Israelita Brasileira

Objetivo: fomentar o ecossistema de empreendedores que acreditam na inovação para transformar a saúde. Além disso, como estratégia de inovação, dezenas de parcerias e projetos têm sido realizados com empresas de tecnologia, laboratórios farmacêuticos, universidades, assim como diversas startups de saúde de todo o Brasil. A Eretz.bio atua como um potencializador e catalisador de oportunidades para todos os indivíduos do ecossistema, gerando um ciclo virtuoso.

\section{Projeto: Incubadora Armazém da Criatividade}

Local: Caruaru/PE

Início das atividades: 2014

Vínculo institucional: Porto Digital de Recife/PE 
Universidades vinculadas: Universidade de Pernambuco (UPE), Universidade Federal de Pernambuco (UFPE), Asces Unita - Centro Universitário Tabosa de Almeida, Centro Universitário UniFavip, Centro Universitário Maurício de Nassau (Uninassau).

Objetivo: oferecer estrutura especial de suporte à inovação $e$ empreendedorismo, que atuam de forma integrada com as instâncias de ensino, ciência e tecnologia e em estreita articulação com o setor produtivo e com as políticas públicas nas regiões onde se localizam. Como resultado, incentivarão o surgimento de novos empreendimentos inovadores para diversificação e fortalecimento da competitividade da economia local.

Baseando-se, ainda, nos conceitos de Marconi; Lakatos (2010), os questionários eletrônicos, após avaliação das respostas, atenderam aos seguintes requisitos: validade: comparando as respostas com fonte externa, observando possíveis dúvidas, ruídos, incertezas demonstradas pelo respondente; relevância: importância perante os objetivos do estudo; especificidade e clareza: referência a dados, datas, nomes, lugares, etc., com objetividade; profundidade: estabelecer relação com pensamentos e nível de conhecimento do projeto pelo respondente, demonstrando sua intensidade e intimidade; extensão: amplitude da resposta.

Além da aplicação do questionário eletrônico, optou-se, pela realização de entrevista não estruturada, com profissional do Sebrae, especialista em incubadoras de empresas, apoiando-se também nos princípios de Marconi; Lakatos (2010) em que afirma que essa modalidade de pesquisa permite ao entrevistador liberdade para desenvolver cada situação em qualquer direção e, desse modo, explorar mais amplamente uma questão ou situações que podem contribuir para o contexto da pesquisa.

A entrevista não estruturada teve como objetivo preencher algumas lacunas, bem como confirmar e confrontar algumas informações identificadas na aplicação da pesquisa com as pré-incubadoras e também agregar novos fatos ao contexto da pesquisa e ainda identificar novas oportunidades de conhecimento e informação para a construção dessa dissertação.

O profissional do Sebrae que foi entrevistado tem mais de 24 anos de experiência em projetos de inovação e empreendedorismo e, dentre os quais, estão inseridos o programa de desenvolvimento de startups, projetos de empreendedorismo 
universitário, transferência de tecnologia entre entidades e empresas, condomínios empresariais e incubadoras de empresas, foco desse estudo.

$\mathrm{Na}$ região de Bauru, foi responsável pela gestão, monitoramento, transferência de recursos, orientação e execução de 7 (sete) incubadoras que já atenderam projetos de empreendedorismo e inovação. Atualmente, existe somente 1 incubadora de empresas em atividade na região de Bauru, localizada na cidade de Lins.

A seguir serão apresentados os resultados e discussão das pesquisas realizadas. 



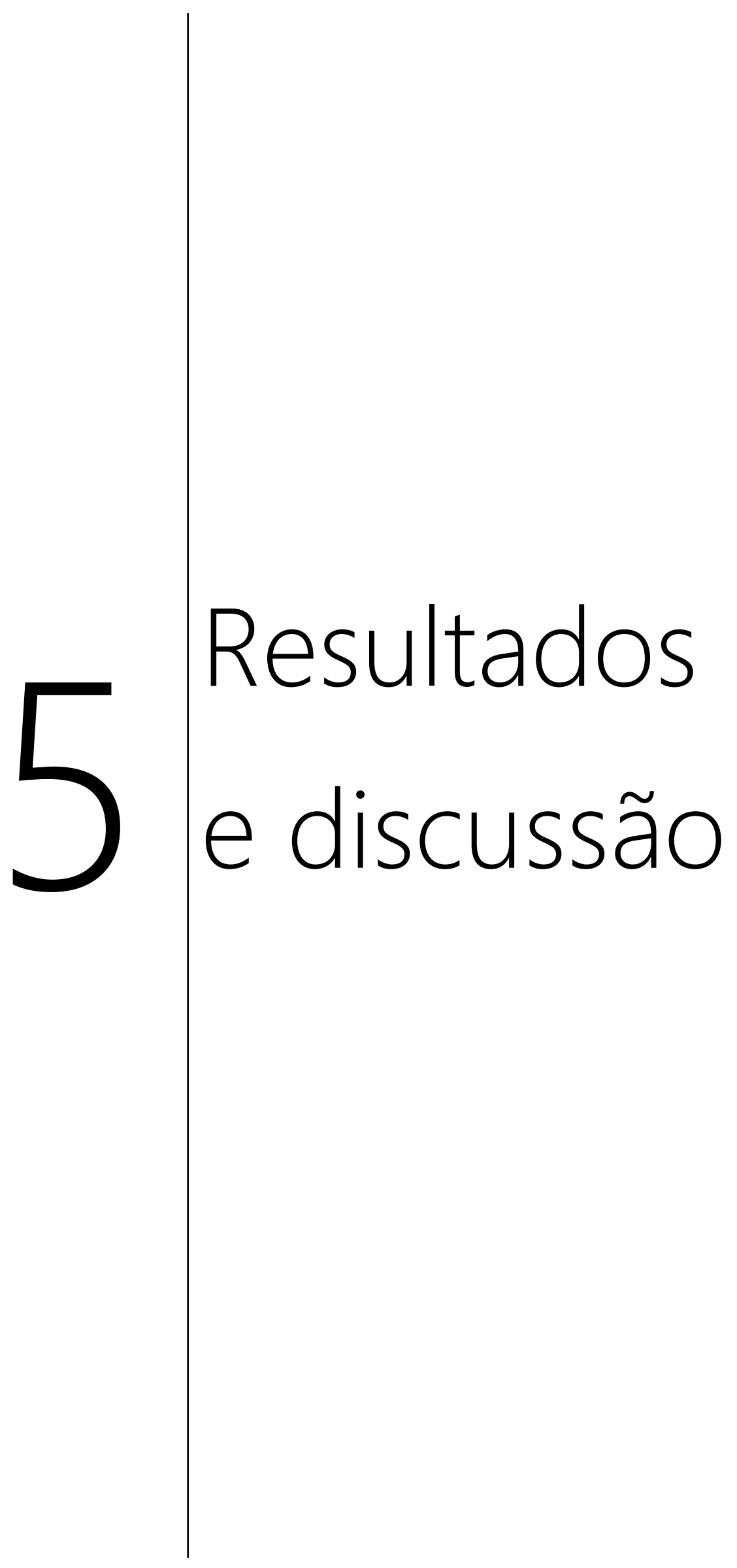





\section{RESULTADOS E DISCUSSÃO}

Após a aplicação do questionário eletrônico, realizou-se a análise das informações sob a ótica do referencial teórico abordado e, nas questões que possuíam respostas abertas, foi utilizada técnica de análise de conteúdo (BARDIN, 2010), sendo consideradas as respostas obtidas como unidades de registro uniformes (palavras ou frases temáticas), os resultados foram analisados e interpretados mediante os conceitos e princípios do referencial teórico construído e apresentados a seguir

Gráfico 1 - Distribuição das pré-incubadoras por natureza

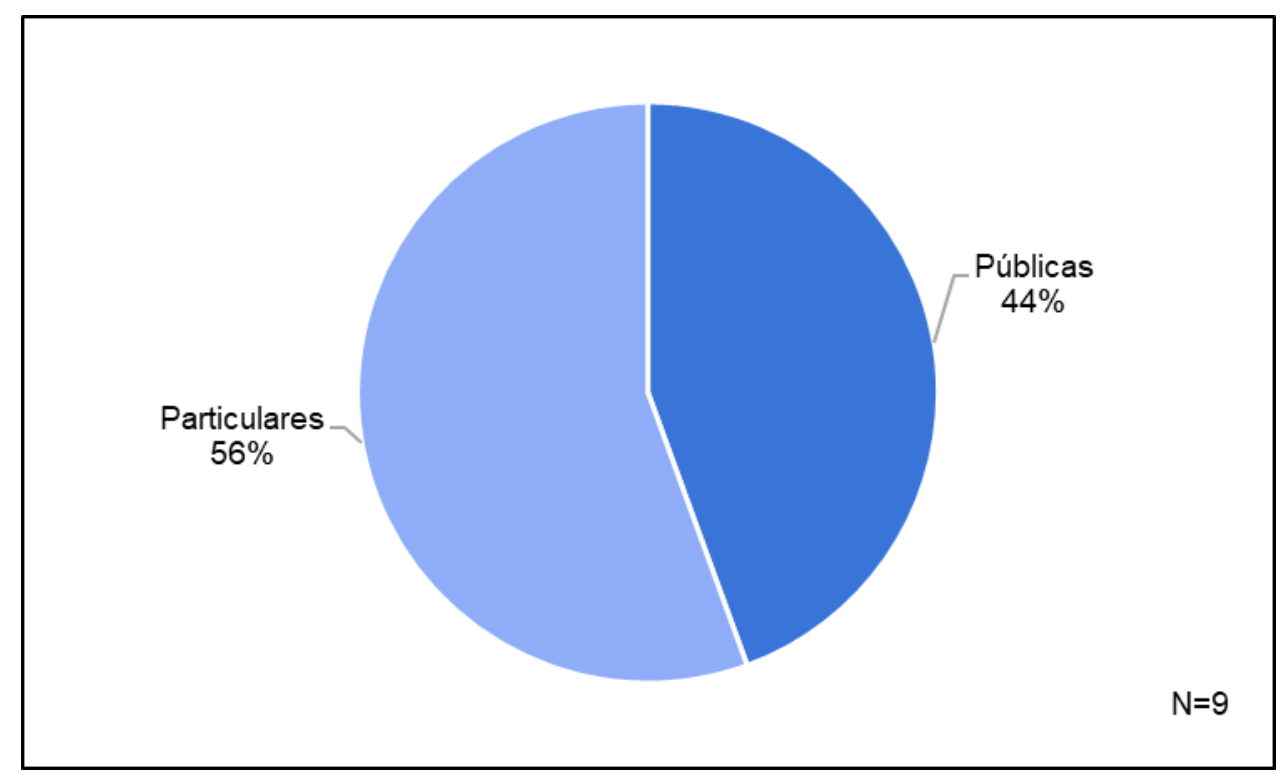

Fonte: elaborado pela pesquisadora (2020)

O Gráfico 1 demonstra o percentual de distribuição das pré-incubadoras por natureza e foi aferido que $56 \%$ das entrevistadas tem origem na iniciativa privada, enquanto que $44 \%$ das pré-incubadoras tem origem em universidades públicas. 0 resultado permite correlacionar essa proporção identificada nessa pesquisa com a pesquisa nacional realizada pela ANPROTEC (2019) com 363 incubadoras, a qual apresenta o percentual de $43 \%$ das respondentes com origem em universidades públicas. Tal indicador demonstra que o universo dos respondentes pode representar uma realidade similar entre projetos da mesma natureza. 
Gráfico 2 - Motivos que levaram a implantação da pré-incubadora na universidade

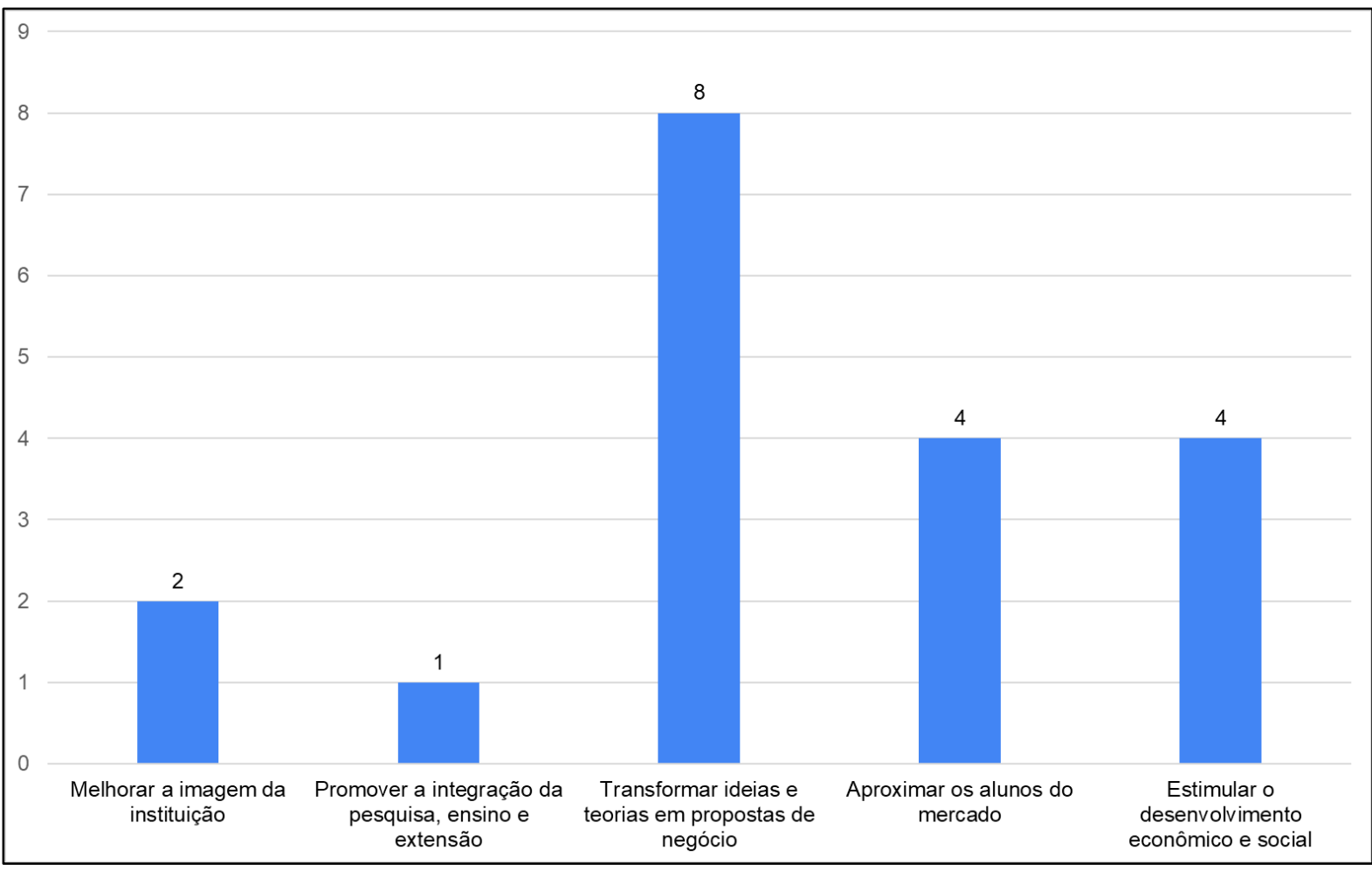

Fonte: elaborado pela pesquisadora (2020)

O Gráfico 2 apresenta o resultado do questionamento sobre os motivos que levaram a implantação da pré-incubadora na universidade. Foram oferecidos 5 principais motivos como alternativa de múltipla escolha e um campo com opção de que descrevessem, opcionalmente, outros motivos. Nenhum dos respondentes optou por descrever qualquer motivo diferente dos indicados nas opções. No entanto, podese identificar que 8 entre as 9 respondentes, ou 89\%, afirmaram que a implantação da pré-incubadora foi com o objetivo de transformar ideias e teorias em propostas de negócio. Com 4 respostas ou 44\%, os respondentes afirmaram que foram motivados para aproximar os alunos do mercado e também para estimular o desenvolvimento econômico e social. Em seguida, com 2 respostas, ou 22\%, identificaram que melhorar a imagem da instituição também motivou a implantação da pré-incubadora e com 1 resposta, ou 11\%, decidiram pela pré-incubadora de empresas para promover a integração da pesquisa, ensino e extensão.

Nota-se que a pesquisa reforçou o conceito e razão de ser das préincubadoras apresentado por INATEL (2020), no qual afirma que as pré-incubadoras têm a missão de contribuir com a ampliação da cultura empreendedora na comunidade acadêmica, esses ambientes oferecem suporte e criam condições para 
que ideias inovadoras se tornem oportunidades de negócio, além de preparar os alunos participantes para o mercado de trabalho, como profissionais com postura e visão empreendedoras.

Gráfico 3 - A pré-incubadora está inserida em outros projetos de empreendedorismo e inovação da universidade

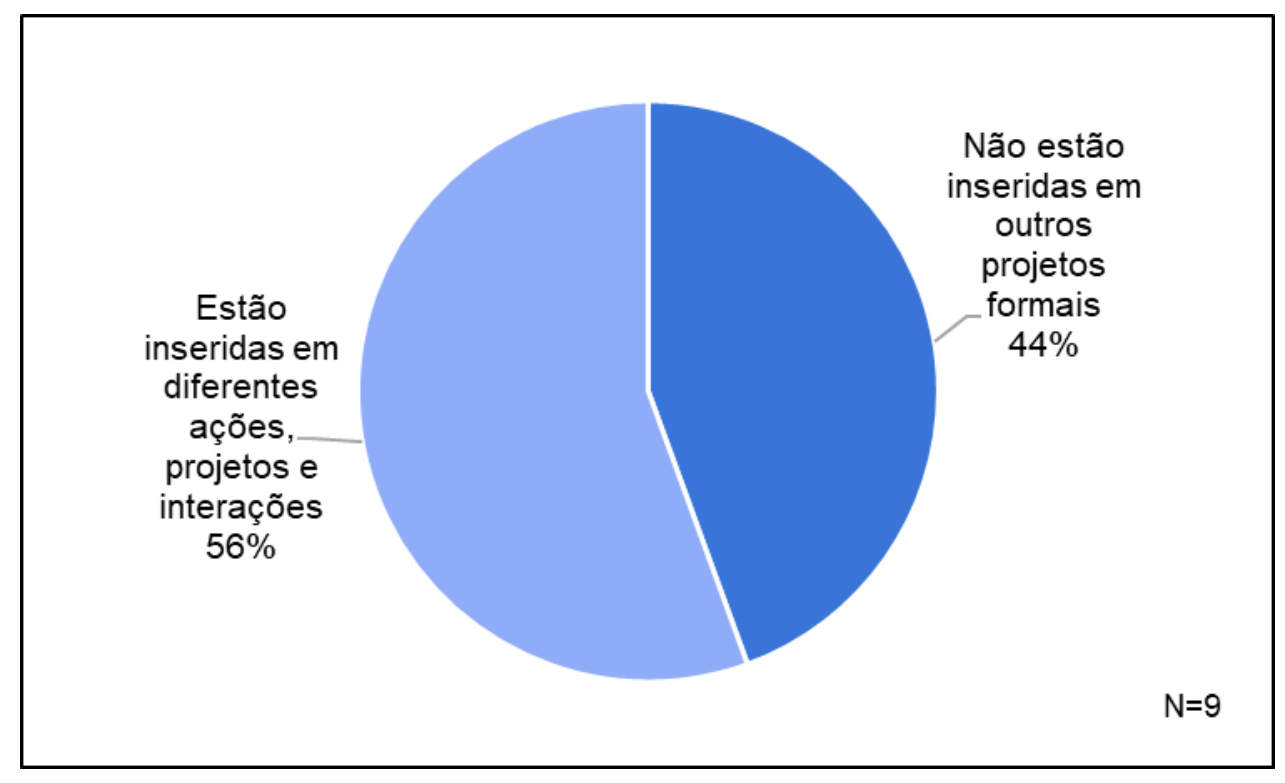

Fonte: elaborado pela pesquisadora (2020)

O Gráfico 3 demonstra o percentual de inserção das pré-incubadoras universitárias em outros projetos de empreendedorismo e inovação na universidade e foi aferido que $56 \%$ das entrevistadas estão inseridas em outros diferentes projetos, ações e interações, enquanto que $44 \%$ das pré-incubadoras não estão inseridas em outros projetos formais de empreendedorismo e inovação. O resultado permite inferir que a maioria das pré-incubadoras estão integradas as universidades em outros projetos acadêmicos de formação empreendedora e/ou de estímulo ao empreendedorismo e inovação.

De acordo com as respostas, evidenciou-se a integração da maioria das pré-incubadoras em outros projetos e ações da universidade como contribuição para o desenvolvimento de uma cultura de inovação e empreendedorismo conforme defendeu Dornelas (2005), ao afirmar que o empreendedorismo é o envolvimento das pessoas e processos que, em conjunto, levam a transformação de ideias em oportunidades. E a perfeita implementação destas oportunidades leva à criação de negócios de sucesso. 
Gráfico 4 - Principais desafios internos e externos que foram enfrentados na implantação da préincubadora

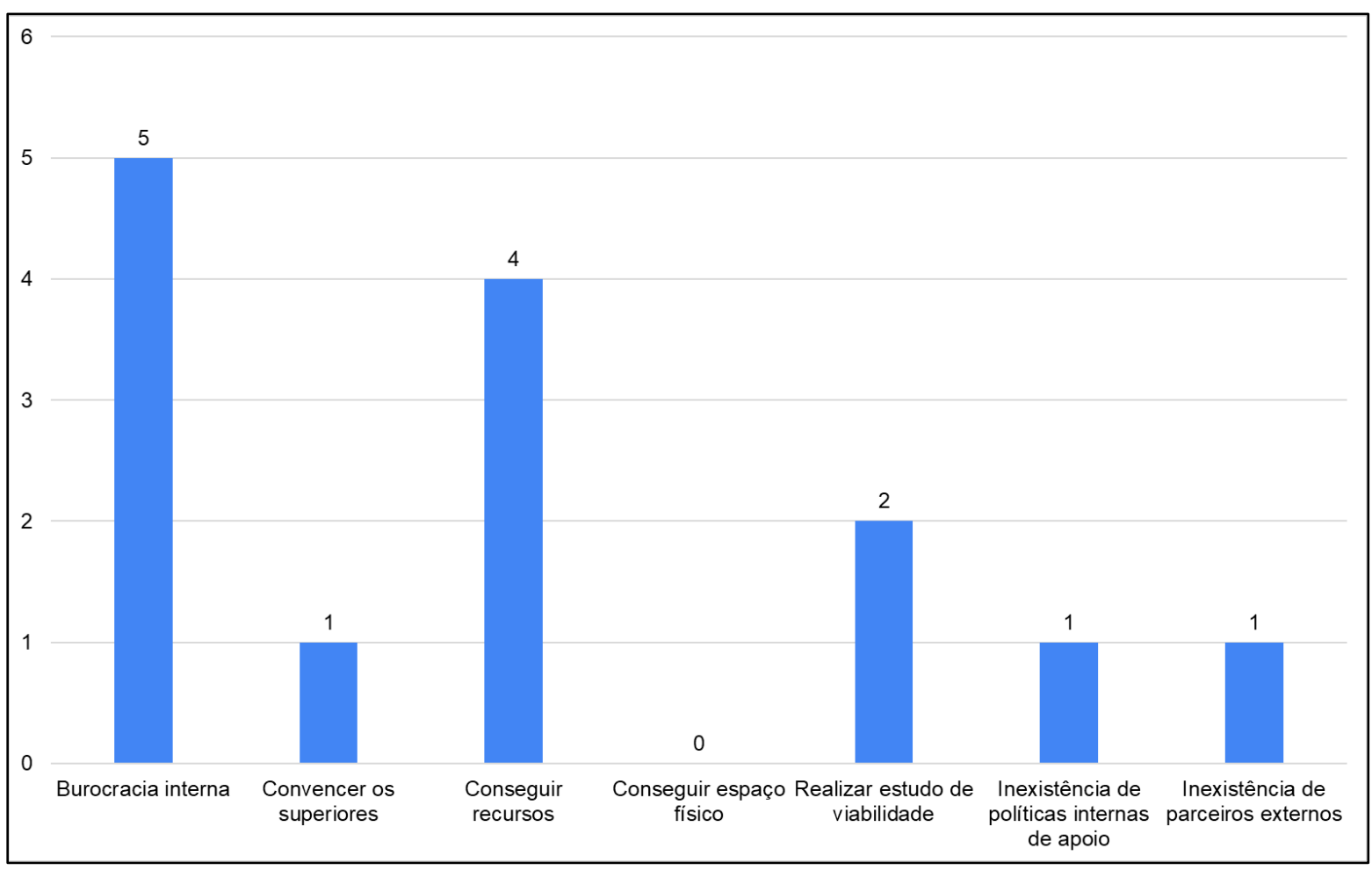

Fonte: elaborado pela pesquisadora (2020)

O Gráfico 4 apresenta o resultado do questionamento sobre os principais desafios internos e externos que foram enfrentados na implantação da préincubadora. Foram oferecidos 7 principais desafios como alternativa de múltipla escolha e um campo com opção, não obrigatório, de apresentação de outros desafios, além dos elencados. Nenhum dos respondentes optou por descrever qualquer desafio além dos indicados nas opções. Pode-se observar que os principais desafios estão relacionados a burocracia interna e conseguir recursos, com 5 , ou $56 \%$, e 4 , ou $44 \%$, respectivamente. Pode-se destacar também que realizar estudo de viabilidade foi identificado como um dos principais desafios apresentados por 2, ou $22 \%$ das préincubadoras respondentes. E ainda, verificou-se que convencer os superiores, a inexistência de políticas internas de apoio ou mesmo, a inexistência de parceiros externos, também foram apontados por 1 , ou $11 \%$ das respondentes como um dos principais desafios enfrentados na implantação. Nenhuma respondente indicou que conseguir espaço físico para a implantação da pré-incubadora foi considerado um desafio. 
Nota-se que a pesquisa reforçou os direcionamentos apontados pelo mapeamento realizado pela ANPROTEC (2019). O qual identificou entre as entrevistadas que para as incubadoras, principalmente, persistem desafios, e dentre estes a necessidade de profissionais qualificados para a sua própria gestão bem como a sustentabilidade do projeto, e que estas condições são afetadas pelo seu estágio de desenvolvimento, o ecossistema e a conjuntura em que se encontra. Ainda, há que se destacar a grande dificuldade que as pré-incubadoras enfrentam na busca e acesso a diferentes mecanismos de apoio e incentivo relatados pelos entrevistados.

Gráfico 5 - Que tipo de apoio a pré-incubadora recebe da universidade?

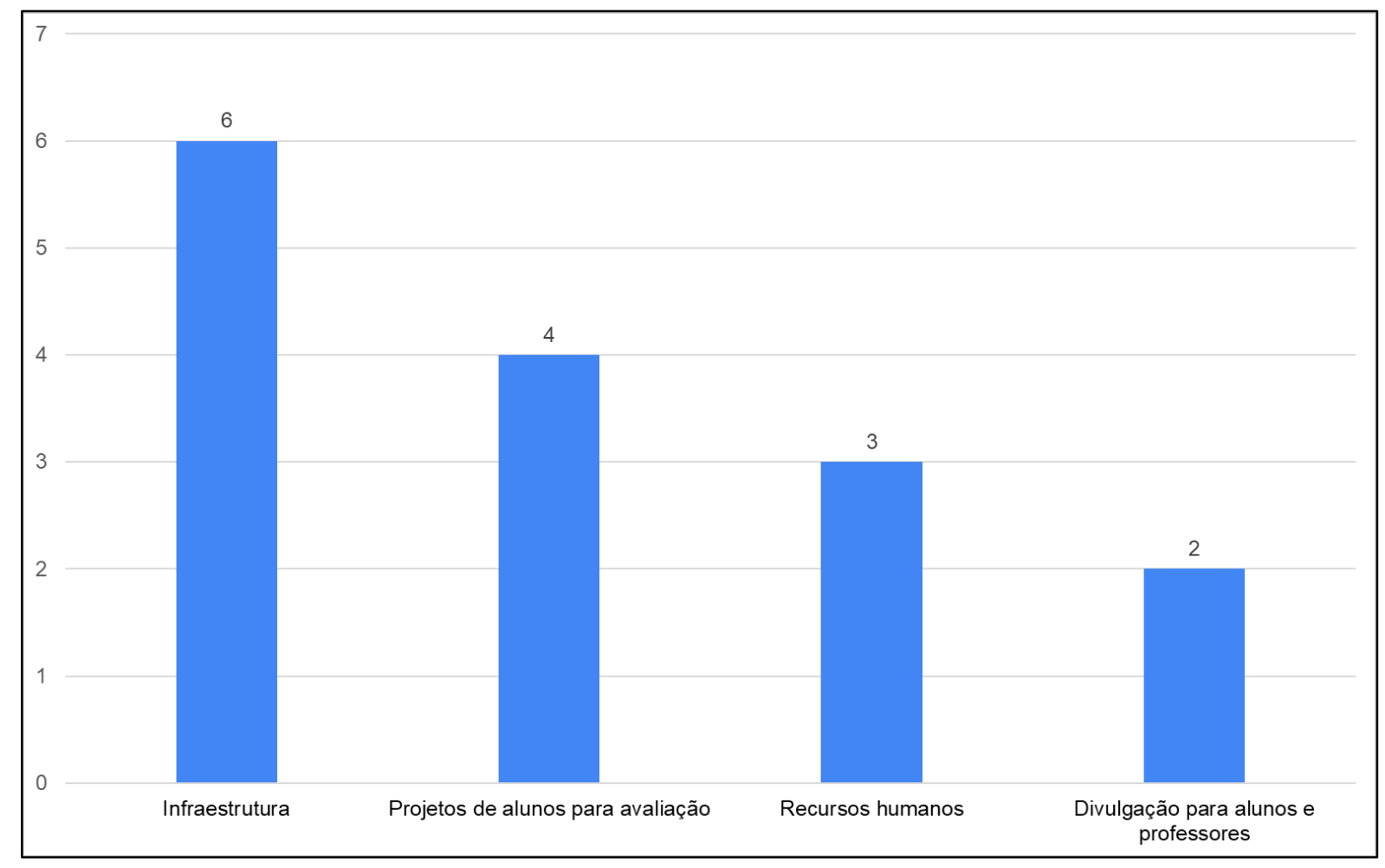

Fonte: elaborado pela pesquisadora (2020)

O Gráfico 5 apresenta o resultado do questionamento sobre o tipo de apoio que a pré-incubadora recebe da universidade. Foram apontados diferentes tipos de apoios: infraestrutura, com 6 indicações, projetos de alunos para avaliação, por 4 respondentes, apoio de recursos humanos, citado por 3 pré-incubadoras, e apoio na divulgação para alunos e professores, por 2 destas. Pode-se destacar que 8 entre as 9 respondentes, ou $89 \%$, afirmaram que recebem algum tipo de apoio da universidade. 
Nota-se que a pesquisa apresentou que além de não ser um desafio para as pré-incubadoras, conforme já demonstrado no gráfico 4, a infraestrutura, agora, conforme demonstrado no gráfico 5 , é apontada como apoio as pré-incubadoras universitárias, corroborando com Medeiros et al. (1992), ao afirmar que esse modelo de pré-incubadora tem como insumo principal o conhecimento e, considerando sua proximidade ou inserção em comunidades universitárias, o resultado dessas ações e projetos criam um diferencial para os empreendedores que podem utilizar as instalações, laboratórios e estruturas da universidade e ofertam diversos benefícios que refletem melhores produtos e serviços à sociedade.

É possível inferir que para a universidade, as pré-incubadoras podem promover e facilitar a produção de conhecimento, pois permitem que pesquisadores, alunos e profissionais desenvolvam estudos sobre as necessidades da sociedade a partir dos projetos incubados, provocando um ciclo de ações com impacto direto no meio em que estão inseridas, como afirmou GOERK (2009).

O apoio dos recursos humanos, bem como, a interação e integração de alunos e professores às pré-incubadoras, criam condições para o desenvolvimento defendido por Paula (2006, p.10) ao afirmar que este exige o crescimento das habilidades, conhecimentos e competências das populações, o que tem sido conceituado como capital humano. 
Gráfico 6 - Parceiros institucionais da pré-incubadora além da universidade

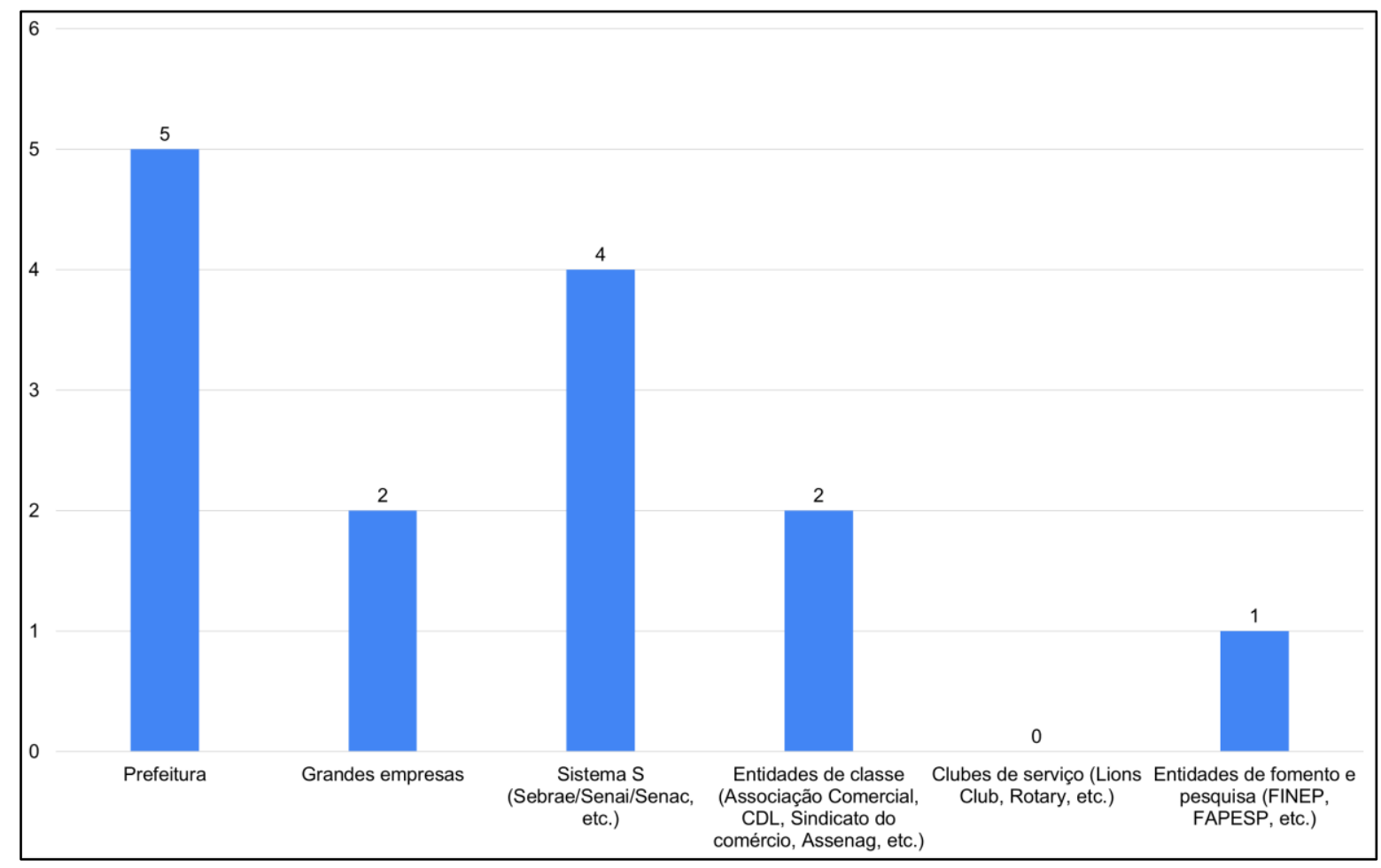

Fonte: elaborado pela pesquisadora (2020)

Conforme pose-se observar no Gráfico 6, com as respostas ao questionamento que além da universidade, quais são parceiros institucionais das préincubadoras, a prefeitura, com 5 indicações, foi apontada pelo maior número dentre as pesquisadas, seguida pelo sistema S, com 4. Já, grandes empresas e entidades de classe, como associação comercial, câmara de dirigentes lojistas, sindicato do comércio, associação de engenheiros, por exemplo, foram indicados por 2 respondentes cada. Entidades de fomento a ciência, tecnologia, inovação, e pesquisa, FINEP, FAPESP, etc., foram indicadas por uma, das 9 respondentes. Nenhuma pré-incubadora, apontou como parceiro institucional, clubes de serviços, como por exemplo, Rotary e Lions.

O Grafico 6, reforça as afirmações de Botelho et al. (2014), sobre a importância de conexões para oferecer os melhores e mais eficientes caminhos que permitem estreitar as relações inerentes ao mercado, visando ampliar as chances de sucesso e fortalecer os negócios e, em decorrência, sua respectiva sobrevivência em um mercado competitivo. 
O questionário aplicado, tentou mapear e identificar quais os tipos de apoio, econômico ou financeiro, aportados por cada um dos parceiros institucionais da préincubadora. De acordo com as respostas obtidas, foi possível sintetizar os tipos de apoio do seguinte modo:

Além do próprio trabalho da mantenedora da pré-incubadora, idealizadora do projeto, parceiros como entidades do Sistema S (Sebrae, Senai, Senac, etc.), entidades de classe, associações de profissionais e outros parceiros técnicos, aportam apoio na forma de recursos econômicos, com consultorias, mentorias, treinamentos, aproximação com fornecedores e compradores, enfim, temas que podem oferecer mais conhecimento, capacitação, conexão e integração da empresa com o mercado.

Parceiros como Prefeituras, Agências de Desenvolvimento, entidades de pesquisa e fomento (FAPESP, FINEP, CNPq, etc.), aportam recursos financeiros. Tais como: locação do imóvel para funcionamento da pré-incubadora, administração e secretaria da pré-incubadora, serviços de segurança e limpeza, inclusive com materiais de limpeza e expediente, para a administração e as áreas comuns da préincubadora, enfim, itens que compõem a estrutura física de funcionamento do projeto.

As respostas encontradas na pesquisa evidenciam os benefícios desses tipos de projetos que foram destacados por Botelho et al. (2014), que entendem as pré-incubadoras como facilitadoras da jornada do empreendedor com o estreitamento e aumento potencial mais e melhores relações e conexões com mercado, governo e universidades, inclusive entre os próprios empreendedores, criando uma rede de apoio colaborativa e virtuosa que, em decorrência, ampliam as chances de sucesso e fortalecem os negócios, aumentando sua sustentabilidade econômica e financeira e suas chances de sobrevivência no mercado.

Além disso, essas estruturas de apoio podem estimular, facilitar e potencializar as ações junto a spin-offs, projetos com grande potencial de desenvolvimento que, segundo Gredel et al. (2012), sofrem ou podem ser engavetados se não obtiverem algum tipo de apoio porque, geralmente, tendem a não progredir devido à falta de recursos físicos e financeiros, à incerteza no desenvolvimento tecnológico, aderência do mercado e deficiências de conhecimento empresarial, descritos por esses autores, como características, em geral, desse público. 
Gráfico 7 - Programas de apoio, públicos ou privados, que a pré-incubadora participa ou participou, além dos programas ofertados pela pré-incubadora

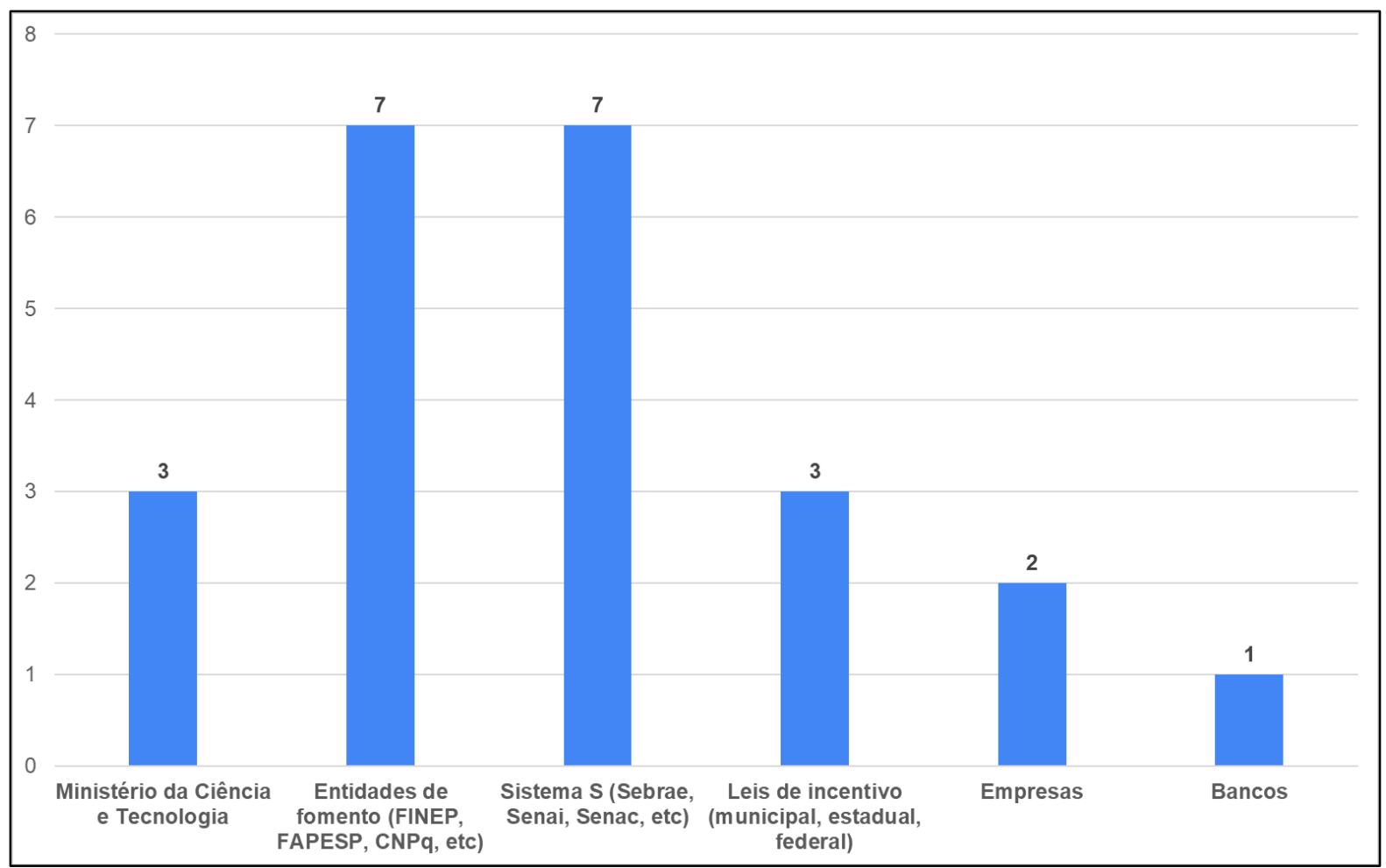

Fonte: elaborado pela pesquisadora (2020)

O Gráfico 7, apresenta as respostas ao questionamento de além das universidades, quais são os programas de apoio, públicos ou privados, que a préincubadora participa ou participou. Entidades de fomento (FINEP, FAPESP, CNPq, etc.), e o Sistema S (Sebrae, Senai, Senac, etc.) foram indicados por 7 préincubadoras cada, maior número dentre as pesquisadas, seguida pelo Ministério de Ciência e Tecnologia e as Leis de incentivo (municipal, estadual ou federal), com 3 indicações cada. Já, empresas, foram indicadas por 2 das respondentes. Bancos, foram indicados por uma pré-incubadora pesquisada. Destacamos que nenhuma das 9 pré-incubadoras indicou que participa ou participou de qualquer programa de apoio das entidades de classe, como associação comercial, câmara de dirigentes lojistas, sindicato do comércio ou associação de engenheiros. 
Gráfico 8 - Quantidade de projetos já apoiados pela pré-incubadora versus projetos que se converteram em negócios ou CNPJ7

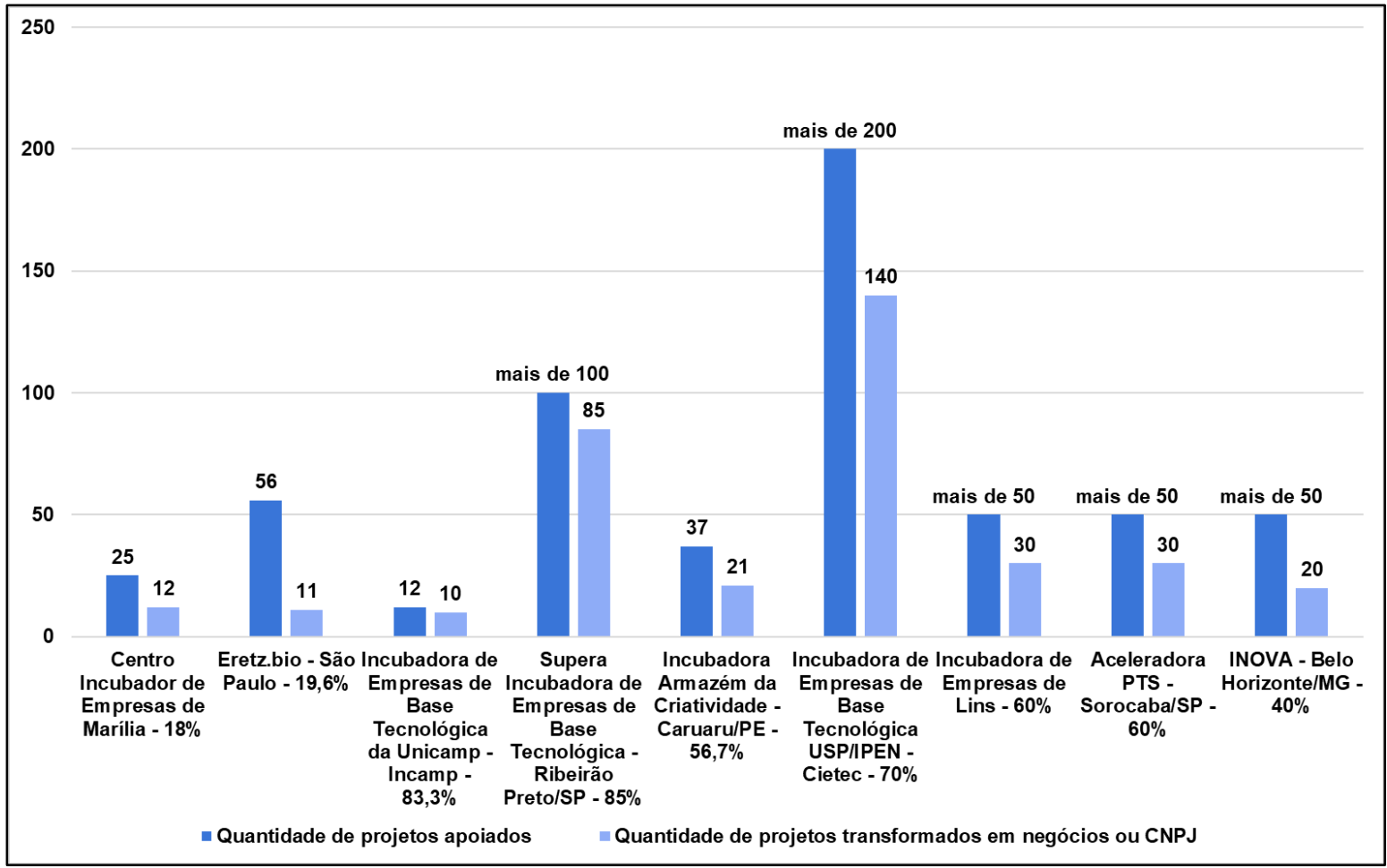

Fonte: elaborado pela pesquisadora (2020)

O Gráfico 8 apresenta um comparativo do resultado dos questionamentos sobre as quantidades de projetos apoiados e de projetos transformados em negócios ou CNPJ, feitos a cada uma das 9 pré-incubadoras pesquisadas.

A taxa de conversão de ideias ou projetos em negócios formais ou CNPJ evidencia diferentes taxas de conversão entre as pré-incubadoras pesquisadas. No entanto, em 6 (seis) das 9 (nove) ou 66,6\% das pré-incubadoras entrevistadas mais de $50 \%$ dos projetos apoiados são convertidos em negócios formais. Ainda assim, 1 (uma) delas apresenta a taxa de conversão de 40\% e 2 (duas) delas apresentam as taxas de $19,6 \%$ e $18 \%$ entre os projetos apoiados.

Deve-se ressaltar nesse ponto que o objetivo maior das pré-incubadoras, de acordo com INATEL (2020) é apoiar projetos ainda não totalmente maduros, que estão na fase de modelação do negócio o mais próximo possível da realidade do mercado, buscando identificar e desenvolver o negócio para que atinja a viabilidade técnica, mercadológica e financeira do projeto/solução em desenvolvimento.

\footnotetext{
${ }^{7}$ Cadastro Nacional de Pessoa Jurídica
} 
Além disso, é importante relembrar aqui que as pré-incubadoras têm a missão de contribuir com a ampliação da cultura empreendedora na comunidade acadêmica, tendo em vista que esses ambientes oferecem suporte e cria condições para que ideias inovadoras se tornem oportunidades de negócio, além de preparar os alunos participantes para o mercado de trabalho, como profissionais com postura e visão empreendedoras (INATEL, 2020).

Outro ponto importante que se deve destacar é que esse tipo de apoio oferecido em ambientes de ensino e pesquisa podem ofertar possibilidades de desenvolvimento de projetos que teriam grande chance de serem esquecidos ou apenas servirem para cumprimento de obrigações de disciplinas, tornando-os potenciais soluções de problemas da sociedade e ainda, com possibilidade de geração de emprego e renda e, em decorrência, promover o desenvolvimento econômico e social da região.

Gráfico 9 - Quantidade de projetos apoiados versus projetos que já receberam aporte financeiro de instituições financeiras, entidades de fomento, investidores ou sócio investidores

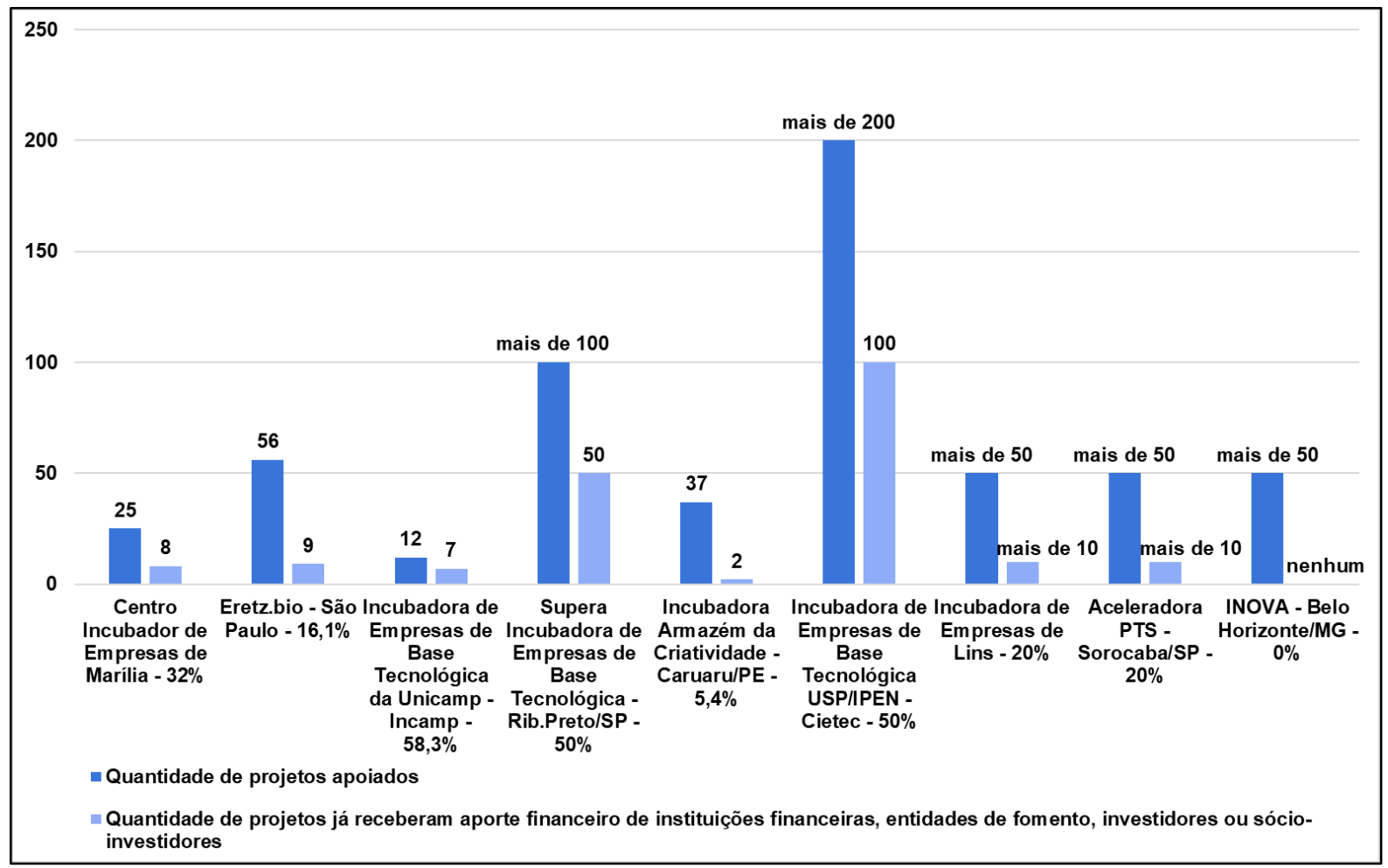

Fonte: elaborado pela pesquisadora (2020)

O Gráfico 9 demonstra a relação existente entre a quantidade de projetos apoiados versus a quantidade de projetos que já receberam aporte financeiro de 
instituições financeiras, entidades de fomento, investidores ou sócio investidores e foi possível verificar que a porcentagem de projetos que já receberam aporte financeiro de instituições financeiras, entidades de fomento, investidores ou sócio investidores, quando apoiados pela pré-incubadora, variam entre $50 \%$ ou mais, para 3 , entre as entrevistadas, ou seja para $33 \%$ destas, $32 \%$, para 1 ou $11 \%, 20 \%$, para 2 , ou $22 \%$, $16 \%$ para 1 , ou $11 \%$, e nenhum projeto para 1 ou $11 \%$ das pré-incubadoras pesquisadas.

Este gráfico talvez represente um dos maiores benefícios de um empreendedor estar vinculado a uma pré-incubadora universitária. Vale relembrar que o IPEA (2020) identificou em pesquisa que as incubadoras participantes desses projetos têm $20 \%$ mais chances de sobrevivência em comparação com empresas que não fazem parte de projetos apoiados. Além disso, reforça também o resultado apresentado na pesquisa do Sebrae (2019) que destacou a dificuldade dos empreendedores na elaboração de projetos de pesquisa e inovação, bem como no acesso a pesquisadores, universidades e centros de pesquisa como um dos principais motivos de encerramento das atividades. Fatores que evidenciam o aumento das chances de sucesso quando esses projetos tem a chance de serem apoiados por préincubadoras universitárias.

Gráfico 10 - Tempo médio de apoio dos projetos pela pré-incubadora

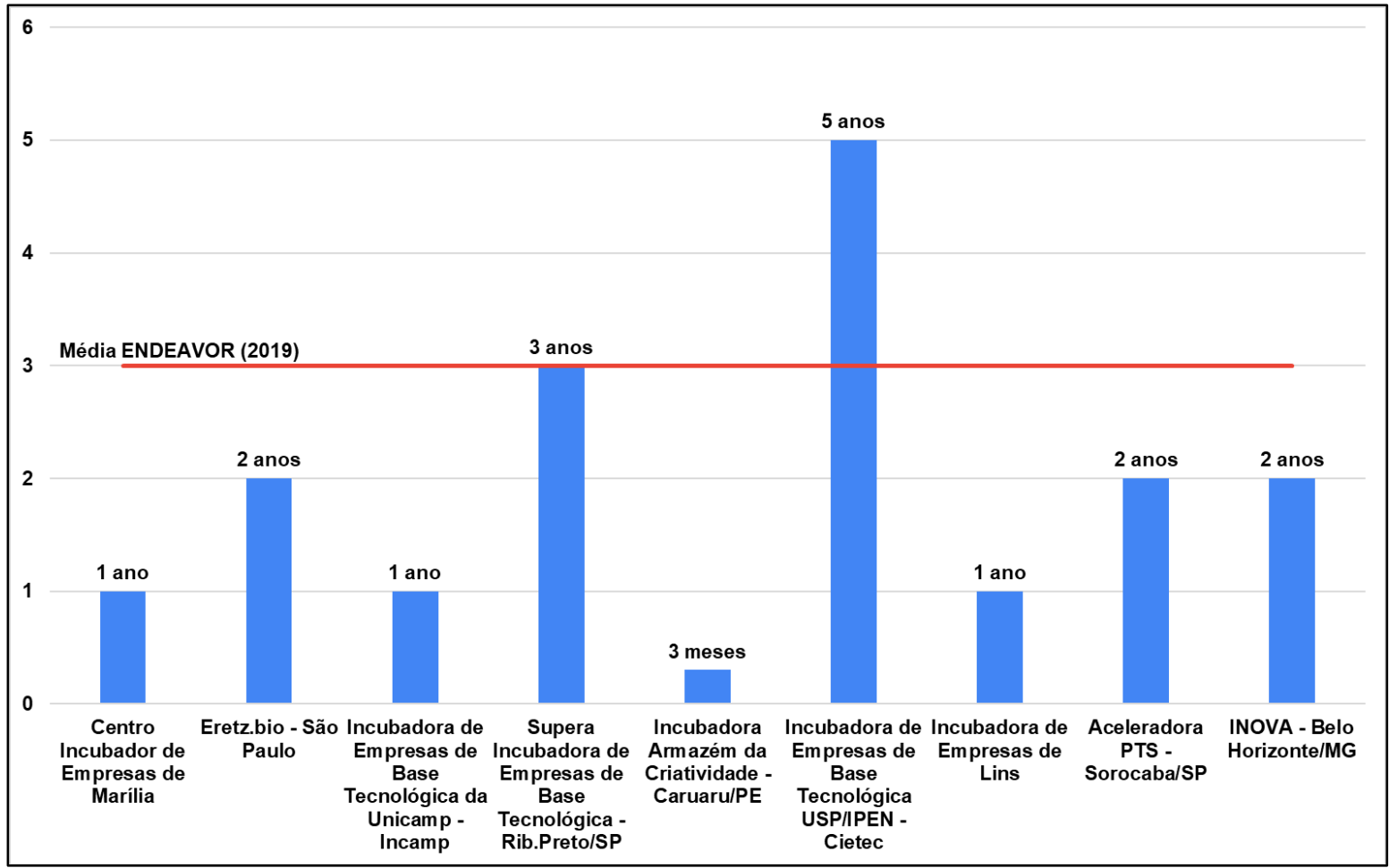


O Gráfico 10 apresenta o tempo médio de apoio dos projetos pela préincubadora e, pelas respostas obtidas com as entrevistadas, foi possível identificar que há uma variação entre 3 meses e 5 anos em média. Sendo que, apenas 1 ou 11\% destas, oferece apoio aos projetos por 3 meses em média, da mesma forma que apenas 1 ou $11 \%$, por 5 anos em média, as demais entre 1 e 3 anos.

Conforme pode ser percebido, $88,8 \%$ das entrevistadas apoiam projetos por até 3 anos. Período em que os empreendedores recebem todo o apoio para o desenvolvimento e maturação do seu projeto e consequente verificação da viabilidade ou não do mesmo. Indicador que corrobora com o tempo médio de incubação levantado pela ENDEAVOR (2020).

Gráfico 11 - Valor médio mensal cobrado por projeto apoiado pela pré-incubadora

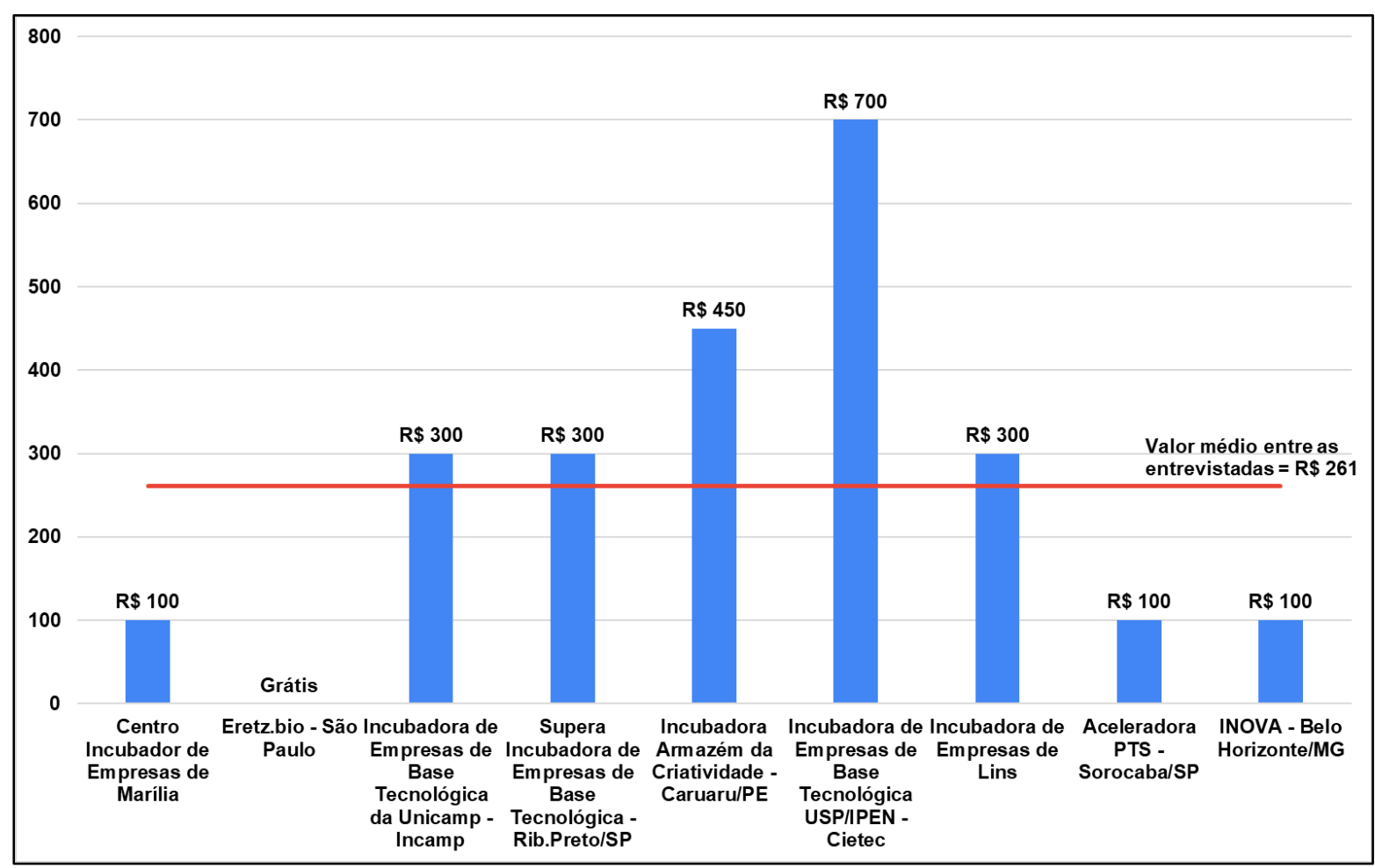

Fonte: elaborado pela pesquisadora (2020)

Ao verificar o Gráfico 11 que apresenta o valor médio mensal cobrado por projeto apoiado pela pré-incubadora, é possível identificar que 3 , das pré-incubadoras entrevistadas, cobram em média $R \$ 100,00$ mensais por projeto incubado, outras 3 , $R \$ 300,00$ em média, 1 das entrevistas, cobra $R \$ 450,00$, bem como, 1 cobra $R \$$ 
750,00. Apenas 1 pré-incubadora, das 9 entrevistas, não cobra qualquer valor pelos projetos apoiados. É possível constatar que o valor médio cobrado pelas préincubadoras é de $R \$ 261,00$ por projeto apoiado.

Os resultados desse gráfico demonstram que o valor é relativamente baixo quando se compara com o valor médio de um aluguel de qualquer espaço físico. Ainda, há de se destacar que estão incluídos nesse valor, todo o apoio recebido pelo empreendedor, conforme ANPROTEC (2019), que lista alguns benefícios como: validação da ideia e modelagem do negócio (CANVAS), construção e validação do MVP - Mínimo Produto Viável, elaboração de um plano de negócio, mentorias e orientações de profissionais especializados, pesquisa de mercado, visitas e missões empreendedoras, estudos de viabilidade, conexões com investidores, outros ecossistemas de inovação, etc.

Gráfico 12 - Vínculo da pré-incubadora com o empreendedor após a graduação do projeto

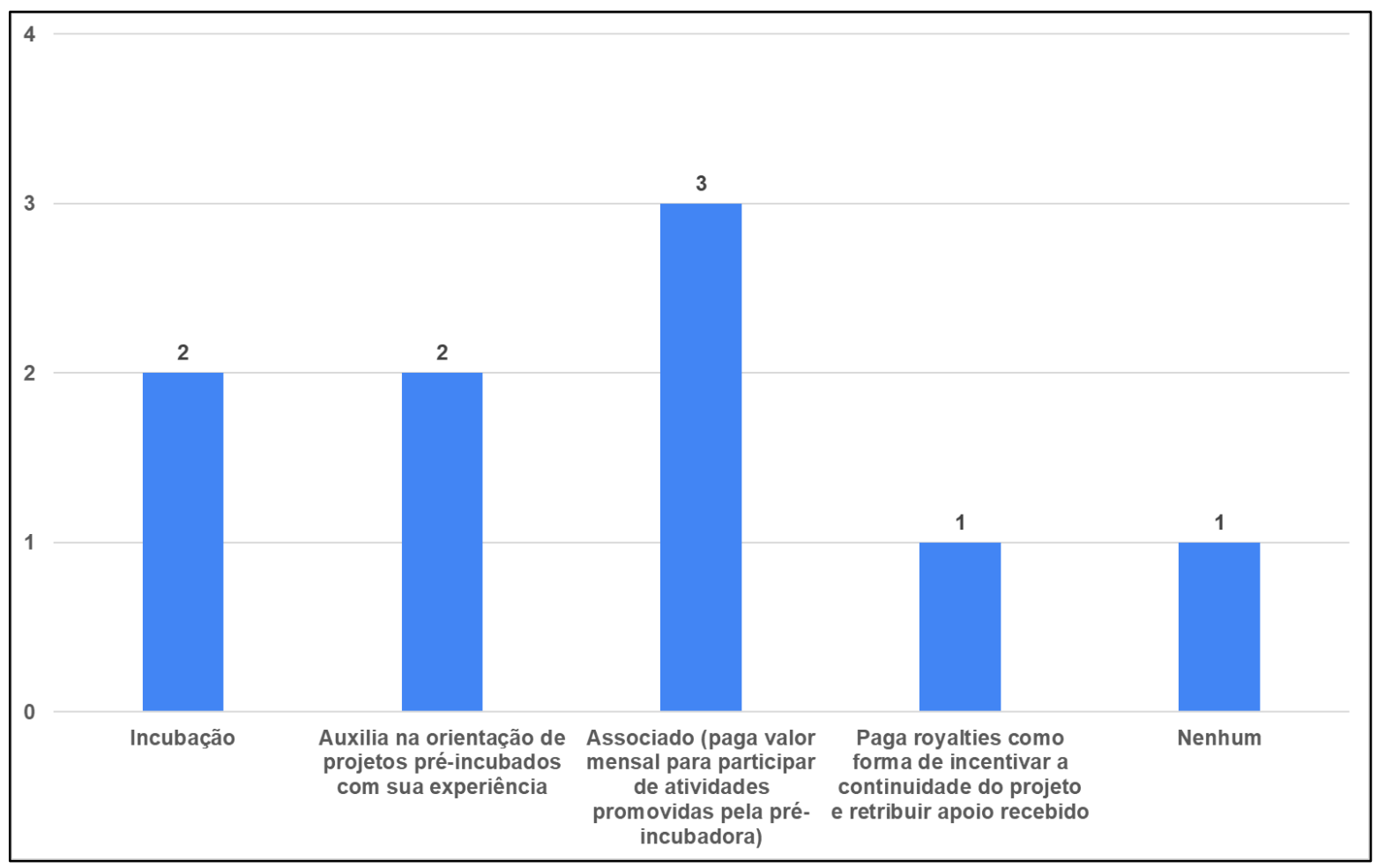

Fonte: elaborado pela pesquisadora (2020)

O Gráfico 12 apresenta o vínculo da pré-incubadora com o empreendedor após a graduação do projeto e pode-se verificar que $89 \%$ das pré-incubadoras pesquisadas mantém diferentes vínculos com os empreendedores que tiveram 
projetos apoiados por estas. Apenas 1 , das 9 pré-incubadoras pesquisadas não mantém vínculos com os empreendedores após a graduação dos projetos apoiados.

É possível destacar também a diversidade de vínculos e benefícios ofertados aos empreendedores pelas pré-incubadoras, mesmo após a graduação dos projetos. Tais como, atividades promovidas pela pré-incubadora a partir de pagamento de mensalidade, incubação em incubadora de empresas mantida pela mesma instituição, auxílio na orientação de novos projetos pré-incubados a partir de suas experiências como empreendedor, e o pagamento de royalties como forma de incentivar a continuidade da pré-incubadora e de retribuir o apoio recebido.

Gráfico 13 - Os projetos apoiados pela pré-incubadora são exclusivamente de alunos, alunos egressos, professores e funcionários da universidade

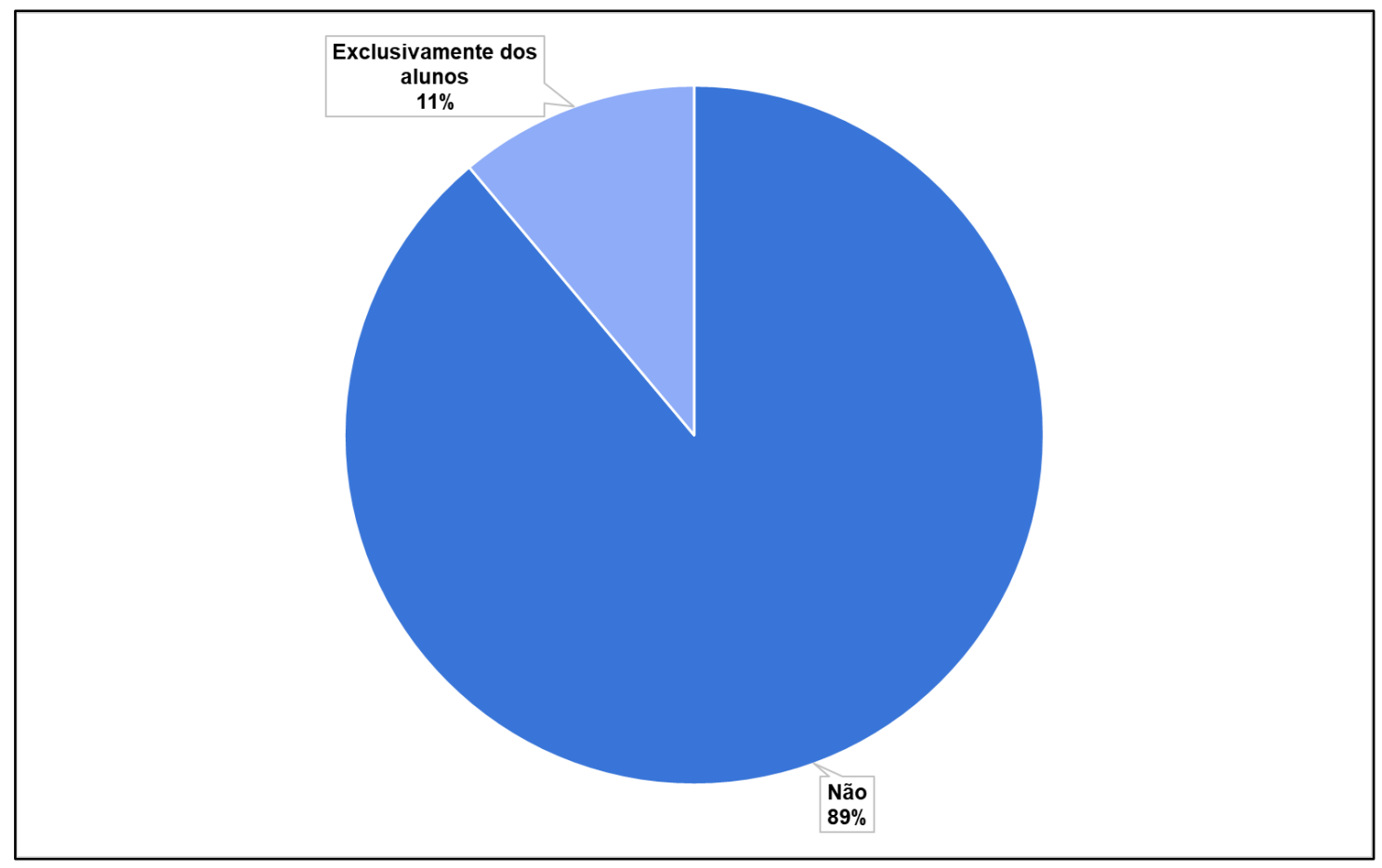

Fonte: elaborado pela pesquisadora (2020)

O Gráfico 13 apresenta o resultado do questionamento sobre a origem dos projetos apoiados pela pré-incubadora, onde $89 \%$ das entrevistadas afirmam que os projetos por estas apoiados não são exclusivamente de alunos, alunos egressos, professores e funcionários da universidade.

Os resultados indicam a disposição das pré-incubadoras pesquisadas em atuarem e interagirem de forma coletiva, importância esta defendida por Wessner (2007), que destaca que essa postura, garante mais a fluidez de conhecimento, maior 
desenvolvimento de inovação e tecnologia, e impactos positivos no mercado onde atuam.

A ANPEI (2020), defende que as pré-incubadoras, como integrantes de um ecossistema de inovação, onde também podem estar inseridos outros importantes atores, como por exemplo, incubadoras, parques tecnológicos, entidades de classe e associações, governos e universidades, dentre outros, constituem-se nesse contexto como parte importante de um conjunto de condições que de forma organizada estimulam a interação e a cooperação entre os diferentes atores e assim podem influenciar positivamente o desenvolvimento de todos os atores envolvidos, e por conseguinte, o desenvolvimento local.

Gráfico 14 - Porcentagem de projetos com origem de pesquisas da universidade

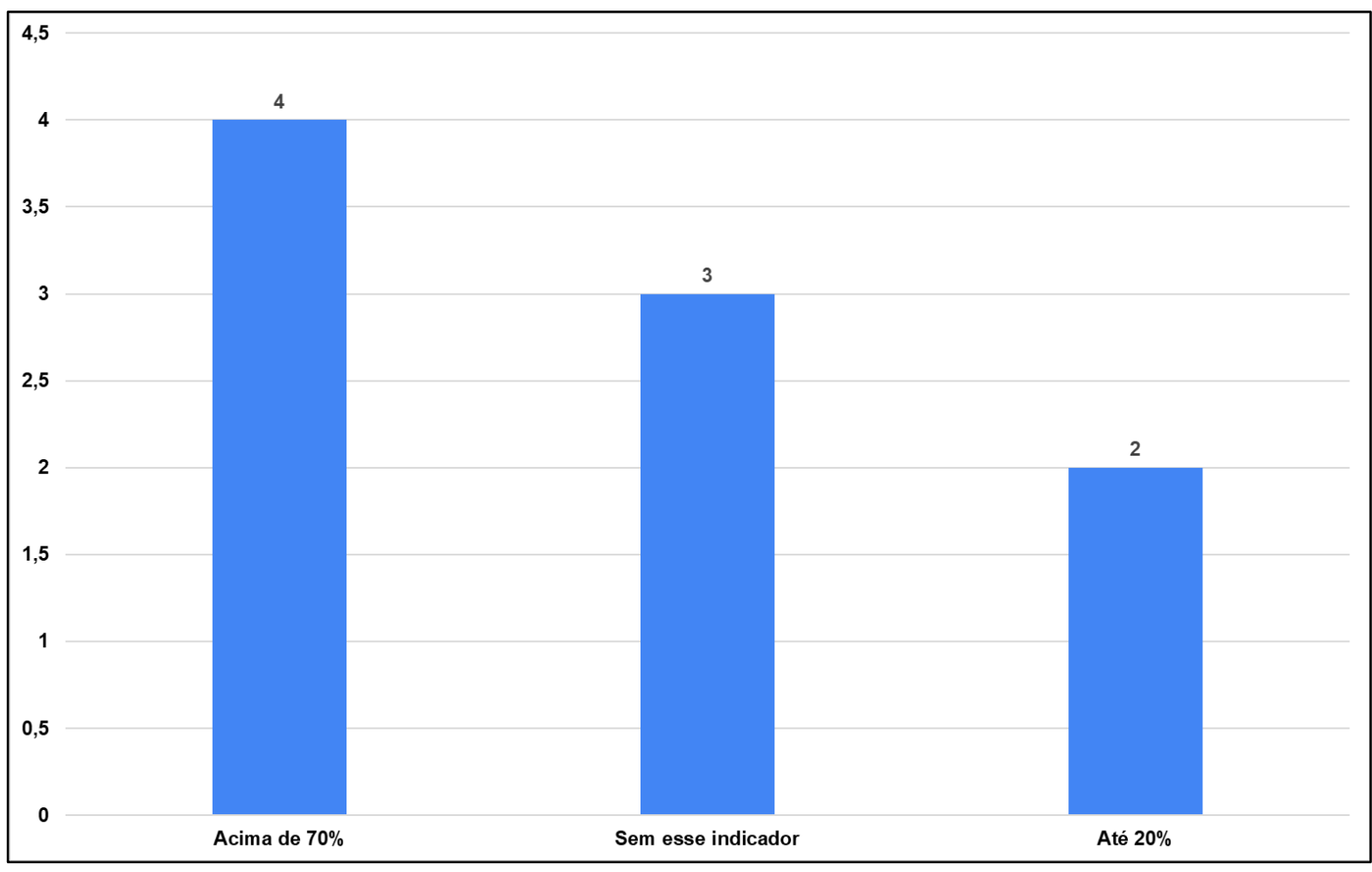

Fonte: elaborado pela pesquisadora (2020)

O Gráfico 14 reuniu as respostas das entrevistadas sobre o percentual de projetos com origem em pesquisas da universidade e pode-se constatar que das 9 pré-incubadoras, 4 delas alegam que os projetos derivados de pesquisa representam mais de $70 \%$ do seu total de projetos apoiados. Outras 2 pré-incubadoras informaram que até $20 \%$ dos projetos apoiados têm origem em pesquisas da universidade. Por 
outro lado, 3 pré-incubadoras afirmam não possuir esse indicador e não necessariamente que não apoiaram projetos oriundos de pesquisa universitária.

Esses resultados permitem identificar que, seguramente, $66,6 \%$ das préincubadoras apoiam projetos derivados de pesquisas universitárias, porém não permitem afirmar que as demais, num total de $34,4 \%$, não apoiem projetos de origem em pesquisas da universidade pois não possuem tal indicador.

No entanto, cabe ressaltar aqui que, os resultados indicam que a pesquisa nas universidades contribui significativamente com projetos para as pré-incubadoras. Fator que consegue comprovar as afirmações de diferentes autores (ABStartups, 2020; Etzkowitz, 2003; Goerk 2009, Sebrae, 2019 e Wessner, 2007) que destacam o papel fundamental da pesquisa universitária para elevar os níveis de qualidade nos negócios, com inovação e conhecimento aplicados no desenvolvimento de novos conceitos e modelos negócios com impacto relevante para os ecossistemas de inovação e empreendedorismo e, em decorrência, para o desenvolvimento econômico e social no contexto em que as pré-incubadoras estão inseridas.

Gráfico 15 - Apoio da pré-incubadora a projetos de outras universidades e de demais parceiros

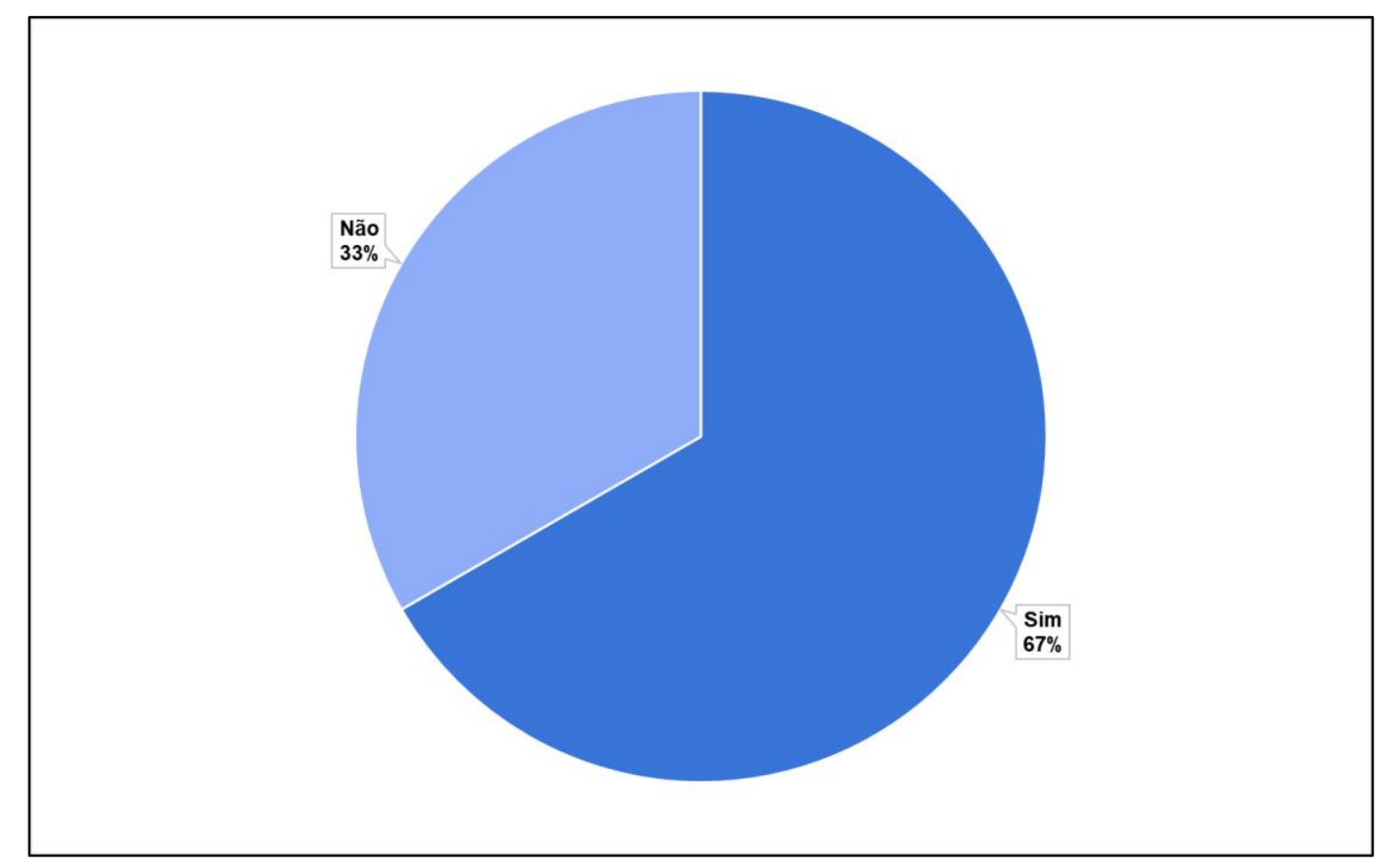

Fonte: elaborado pela pesquisadora (2020) 
O Gráfico 15 apresenta o resultado do questionamento sobre o apoio da pré-incubadora a projetos de outras universidades e de demais parceiros, onde $67 \%$ das entrevistadas afirmam que oferecem esse tipo de apoio e 33\%, que não apoiam.

Ainda foi possível identificar a partir das respostas ao questionamento feito as pré-incubadoras pesquisadas que o apoio oferecido por estas, na forma de parceria, está condicionado a alguns critérios, conforme relatado: incubadoras/aceleradoras ${ }^{8}$ que possuem projetos em saúde, projetos inovadores e de base tecnológica, projetos aprovados em processo seletivo próprio, projetos que tenham conexão com os objetivos da pré-incubadora, e ainda, que estes apoios estão relacionados a facilidades oferecidas na entrada para participar de programas da préincubadora, ou na oferta de mentorias e conteúdo.

Gráfico 16 - Principais benefícios/serviços oferecidos aos projetos apoiados pela pré-incubadora

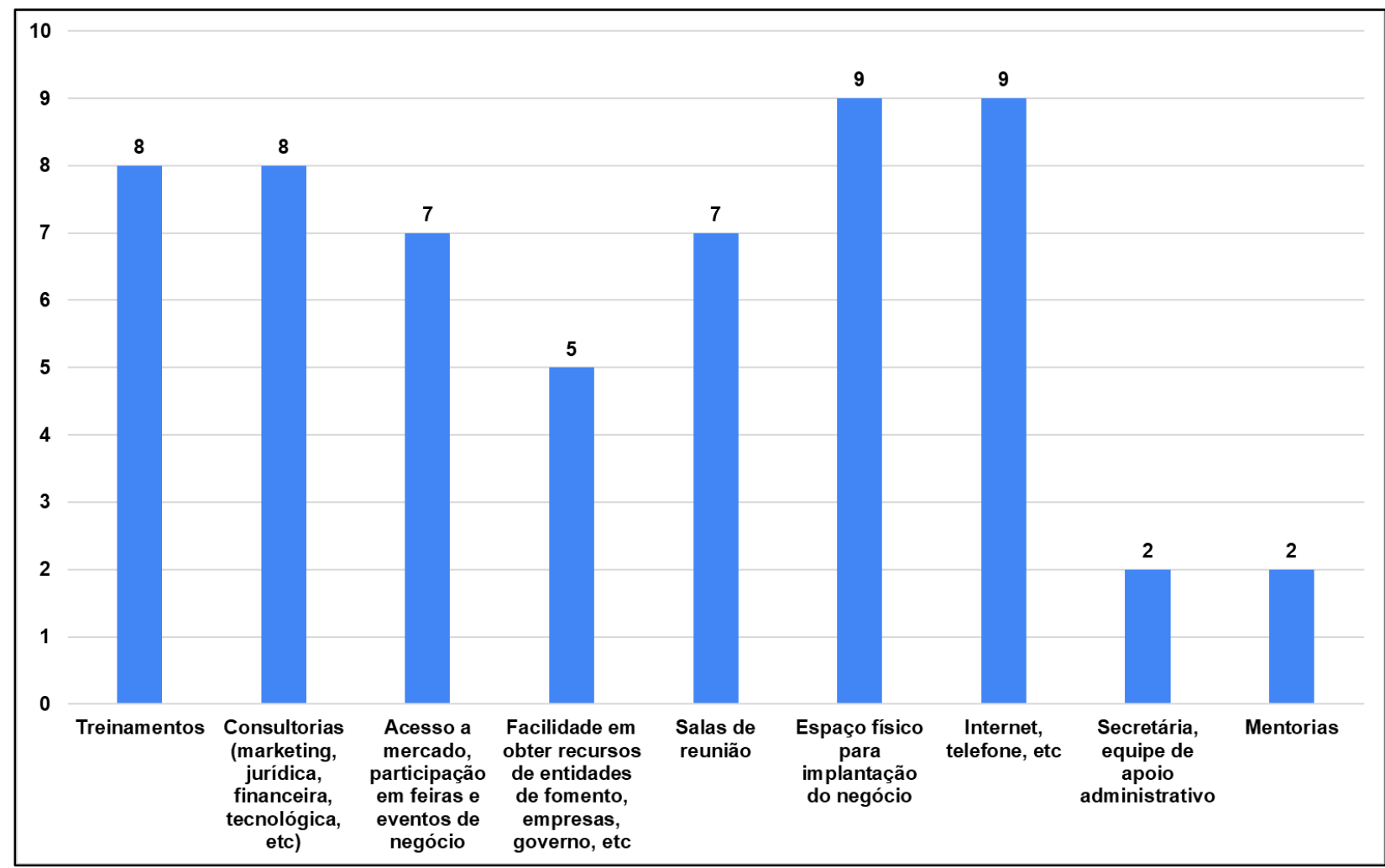

Fonte: elaborado pela pesquisadora (2020)

O Gráfico 16 apresenta os resultados ao questionamento sobre os principais benefícios/serviços oferecidos aos projetos apoiados pela pré-incubadora,

\footnotetext{
8 Aceleradoras: entidades cujo objetivo principal é apoiar e investir no desenvolvimento e rápido crescimento de ideias, projetos e negócios nascentes, ajudando-as a obter apoio de investidores ou a atingir seu ponto de equilíbrio.
} 
e pode-se observar que 9 ou 100\% das pesquisadas, recebem espaço físico para a implantação do negócio, e internet, telefone, etc., 8 ou 89\%, oferecem também, treinamentos e consultorias (marketing, jurídica, financeira, tecnológica, etc.), 7 ou $78 \%$, oferecem acesso a mercado, participação em feiras e eventos de negócio e salas de reuniões, 5 pré-incubadoras ou $56 \%$, oferecem facilidade em obter recursos de entidades de fomento, empresas, governos, etc., e 2 ou $22 \%$ também oferecem secretária, equipe de apoio administrativo e mentorias.

Gráfico 17 - Oportunidades geradas a partir da pré-incubadora para a universidade

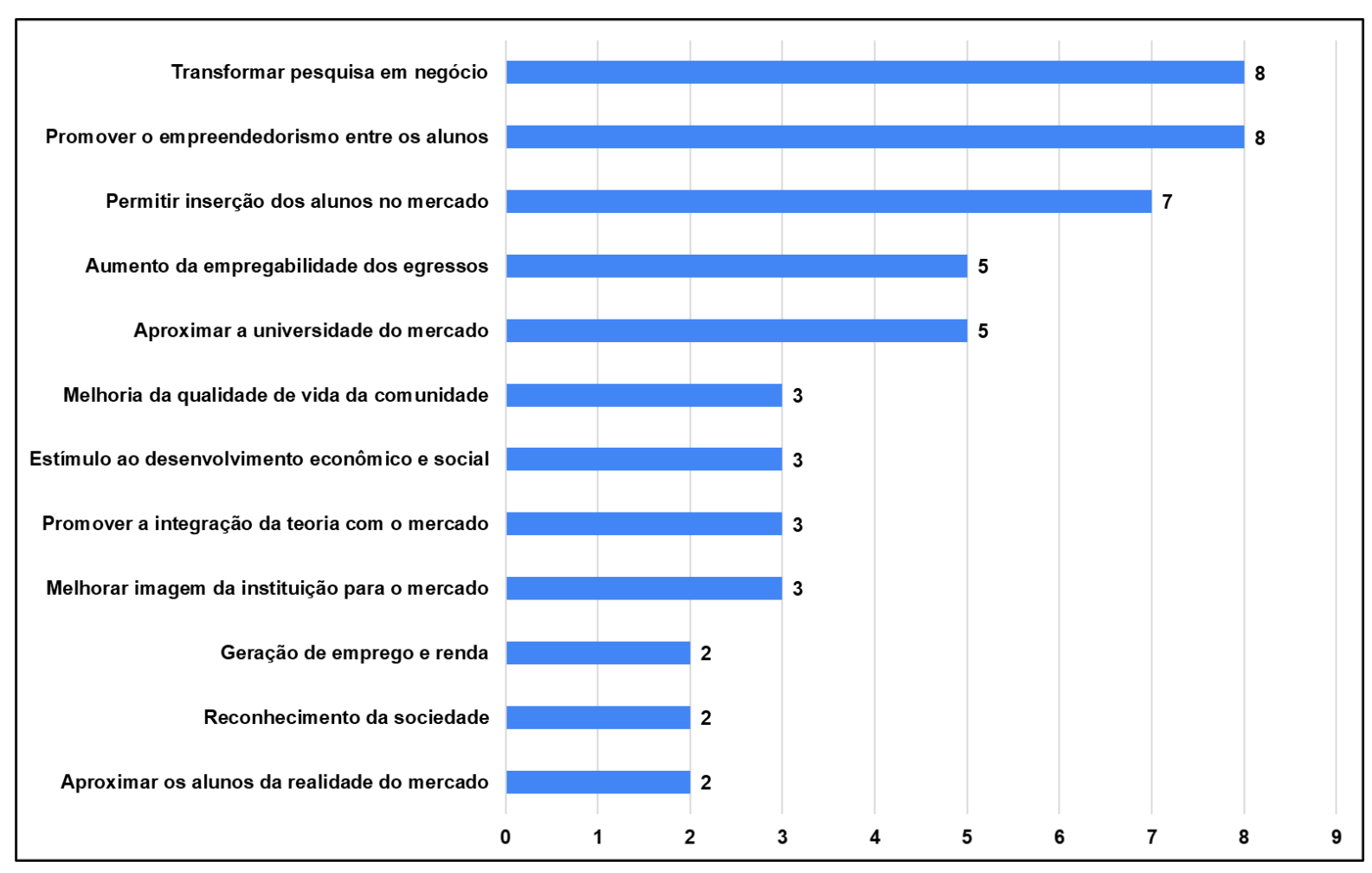

Fonte: elaborado pela pesquisadora (2020)

Ao analisar o Gráfico 17 pode-se observar que diferentes oportunidades são geradas para a universidade a partir da pré-incubadora. Para 8 das préincubadoras pesquisadas, as universidades recebem a oportunidade de transformar pesquisa em negócio e promover o empreendedorismo entre os alunos, 7 destas relatam que permitem inserção dos alunos da universidade no mercado, para 5 das pesquisadas, garantem aumento da empregabilidade dos egressos e também citam aproximar a universidade do mercado. É indicado por 3 pré-incubadoras que as universidades têm a oportunidade de melhorar a qualidade de vida da comunidade, estimular o desenvolvimento econômico e social, promover a integração da teoria com 
o mercado e melhoram a sua imagem institucional perante ao mercado. Também foram apontados como oportunidades para as universidades a geração de emprego e renda, reconhecimento da sociedade, e a aproximação dos alunos da realidade do mercado, por 2 pré-incubadoras.

Gráfico 18 - Há resultados positivos da pré-incubadora para o desenvolvimento econômico e social da cidade/região de atuação?

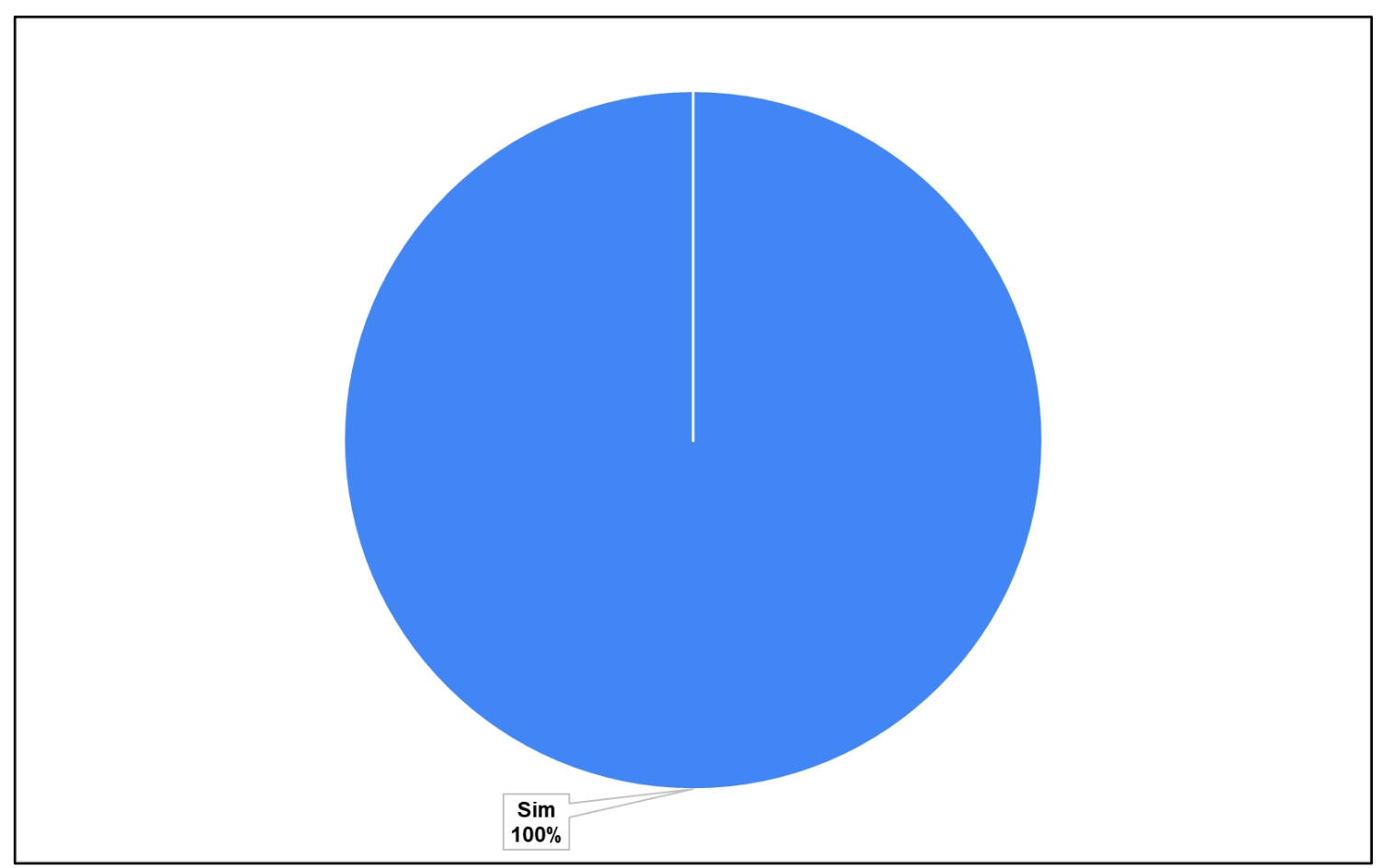

Fonte: elaborado pela pesquisadora (2020)

O Gráfico 18 apresenta que $100 \%$ das pesquisadas afirmam que há resultados positivos da pré-incubadora para o desenvolvimento econômico e social da cidade/região de atuação.

Esses resultados estão em perfeita sintonia com as afirmações de Vieira; Santos (2012) quando afirmam que as políticas de desenvolvimento econômico objetivam promover a atração de investimentos acompanhados de inserção tecnológica e que seu objetivo primeiro é direcionado para aumentar a produtividade do trabalho que refletirá competitividade regional e que, em decorrência farão com que impactem diretamente no aumento na melhoria das condições humanas em um determinado território.

Ainda, de acordo com as respostas, foi possível identificar os seguintes resultados para a cidade e região, citados pelas entrevistadas: reconhecimento do 
ecossistema de inovação da cidade e contribuição com o arranjo produtivo local ${ }^{9}$ de tecnologia da informação da cidade; projetos de impacto social para melhoria da saúde populacional, empregos nos projetos em parceria, renda ao município com os CNPJ emitindo notas fiscais; pesquisas e transferência de conhecimento e tecnologia, geração de vários empregos; aumento da arrecadação de impostos; geração de mais negócios para o interior do estado; ao apoiar projetos como esse, consegue-se provocar o aquecimento da economia e tornar uma cidade mais competitiva, com melhores chances de desenvolvimento econômico e social, com mais possibilidade de melhorar sua posição no ranking das cidades para se fazer negócio no país; parte das empresas que passaram pela pré-incubação, gradua-se e hoje são empresas pequenas e médias; grande parte das empresas empregam pessoas e contribuem com impostos para a região; e gerar e fomentar empreendedorismo.

Com base nesses resultados apresentados e na entrevista não estruturada realizada com profissional do Sebrae, foi possível identificar fortes indícios para a viabilidade técnica de implantação de uma pré-incubadora de empresas na área da saúde para a Faculdade de Odontologia de Bauru - FOB-USP e, para tanto, congregando as informações identificadas na pesquisa bibliográfica, na pesquisa realizada com as pré-incubadoras com diferentes perfis e diversidades regionais, além da entrevista não estruturada realizada com o profissional do Sebrae, apresenta-se à seguir, uma proposta de modelo de pré-incubadora.

\section{PRÉ-INCUBADORA TECNOLÓGICA FOB-USP (preâmbulo)}

A pré-incubadora deverá ser uma instituição que auxiliará pesquisadores, empreendedores, que tenham como principal característica a oferta de produtos e serviços no mercado com significativo grau de inovação. Ela poderá oferecer suporte técnico, gerencial e formação complementar ao empreendedor e facilitar o processo de inovação e acesso a novas tecnologias nos pequenos negócios.

Além de receberem suporte gerencial, administrativo e mercadológico, os participantes do projeto poderão receber apoio técnico para o desenvolvimento do seu produto. Com isso, o empreendimento poderá ser acompanhado desde a fase de planejamento até a consolidação de suas atividades com mentoria de especialistas.

9 Conjunto de fatores econômicos, políticos e sociais, localizados em um mesmo território, desenvolvendo atividades econômicas correlatas e que apresentam vínculos de produção, interação, cooperação e aprendizagem. 
A pré-incubadora poderá oferecer ainda, espaço físico especialmente construído ou adaptado para alojar temporariamente os empreendedores - chamados neste momento de projetos ou empresas pré-incubadas - e promover acesso a serviços que os empreendedores dificilmente encontrariam agindo sozinhos e sem orientação adequada no mercado.

Além deste espaço individualizado para a instalação de escritórios ou laboratórios, a pré-incubadora poderá compartilhar sala de reunião, auditórios, área para demonstração dos produtos, secretaria, bibliotecas e uma série de outros benefícios por meio de parcerias com instituições de ensino e pesquisa, órgãos governamentais e iniciativas privadas.

Considerando o momento atual, ao ser aceito com seu projeto na préincubadora, o empreendedor, poderá ter vínculo virtual com o projeto, tendo acesso a todos os serviços e benefícios de um projeto presencial convencional.

Proposta de Missão para a pré-incubadora:

Dar suporte à geração e o desenvolvimento de projetos e negócios inovadores, sustentáveis e de impacto social, por meio de métodos de apoio e incentivo próprios ou de parceiros, fomentando o uso intensivo de tecnologias e 0 desenvolvimento econômico e social de Bauru e região.

Proposta de Objetivo para a pré-incubadora:

Estruturar o sistema de inovação da FOB-USP para aproximar e fortalecer o encadeamento produtivo, do ensino, pesquisa, extensão e inovação, através de programa de pré-incubadora de projetos apoiados em tecnologia.

Os projetos de pré-incubadora de empresas devem servir para dar amparo, capacitação e mentorias às ideias e soluções de empreendedores nos seus primeiros anos de vida, fase em que precisam de mais apoio e que podem ser importantes para o seu desenvolvimento em curto período de tempo. Durante o período de préincubação e à medida em que os projetos são estruturados e os empreendedores capacitados, os riscos inerentes à atividade empreendedora tendem a diminuir. Como pode ser observado na Figura 2 criada a partir da pesquisa realizada. 
Figura 2 - Ciclo de risco de projetos pré-incubados

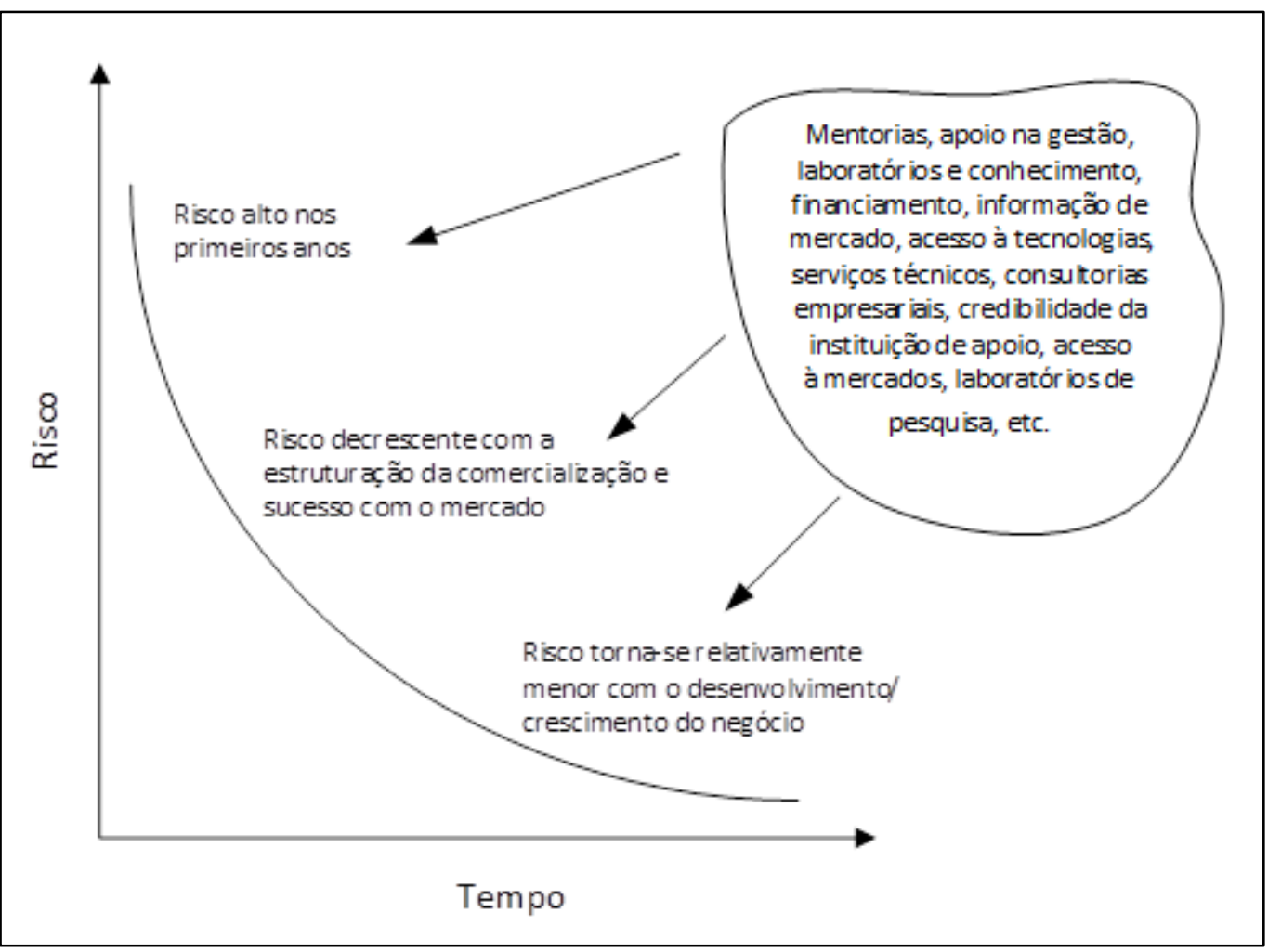

Fonte: elaborado pela pesquisadora (2021)

Ainda em contribuição ao modelo proposto para implantação da préincubadora, estabeleceu-se, baseando-se nas informações levantadas na pesquisa, o ciclo de incubação de projetos em uma pré-incubadora, que pode ser observado na Figura 3.

Figura 3 - Ciclo de pré-incubação de projetos

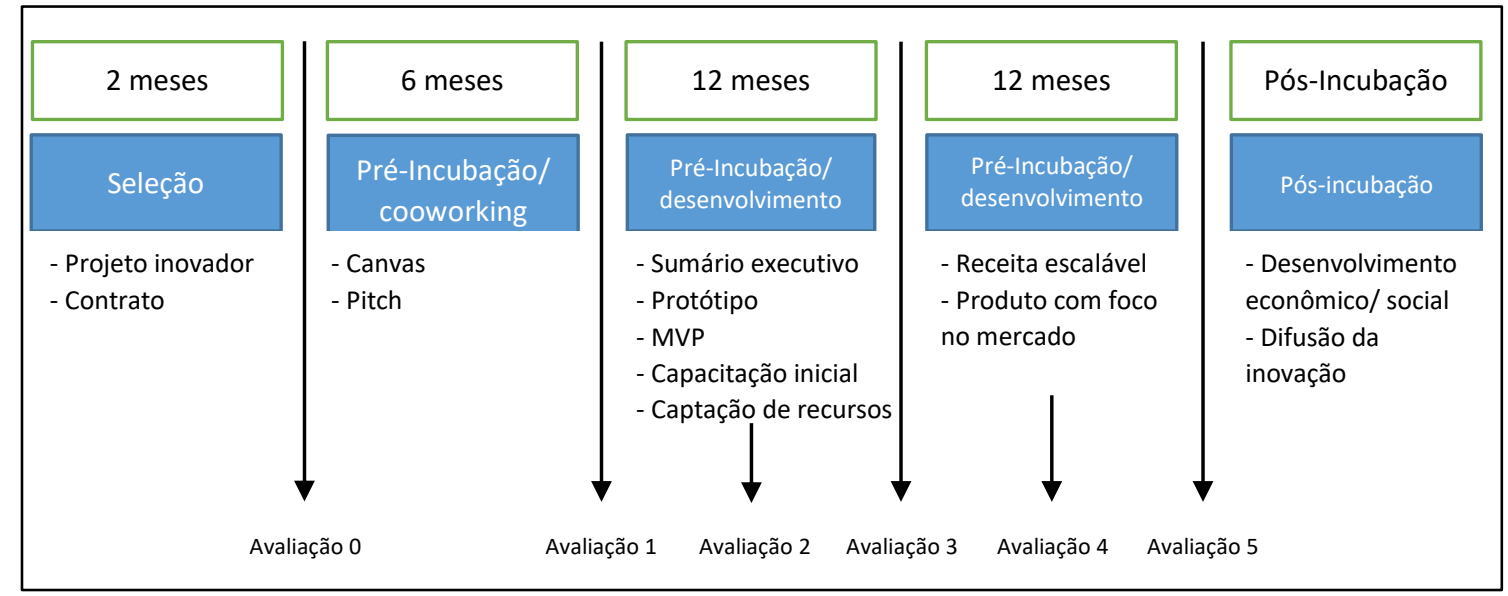

Fonte: elaborado pela pesquisadora (2021) 


\section{Proposta de processo de seleção}

Nessa fase, com duração de até 2 meses, através de edital, devem ser selecionados projetos de acordo com perfil de projetos definidos pelo conselho gestor da pré-incubadora. Ao ser selecionado, o projeto passa pela primeira avaliação (avaliação 0) para identificar o perfil do empreendedor, potencial do negócio, aderência ao projeto da pré-incubadora, tempo de dedicação ao desenvolvimento do projeto e equipe.

\section{Pré-Incubação / Cooworking}

Nessa fase, que pode durar até 6 meses, o empreendedor terá contato com mentorias e capacitações introdutórias, presencial ou virtual, para desenvolvimento do seu projeto e para estruturar o quadro de modelo de negócios ou "canvas" e apresentar o seu Pitch ${ }^{10}$ para uma banca avaliadora (avaliação 1). O objetivo deverá ser avaliar se a ideia apresentada pelo empreendedor tem potencial e/ou viabilidade técnica e econômica ou se há realmente um problema a ser resolvido.

Pré-Incubação - desenvolvimento

Ao ser pré-incubado, o projeto passa a receber as mentorias, capacitações e orientações oferecidas pela pré-incubadora para desenvolvimento do seu projeto e para a construção do Sumário executivo (plano de negócios), Protótipo, Mínimo Produto Viável (MVP), Capacitações, Captação de recursos, desenvolvimento de um modelo de receita escalável e um produto com foco no mercado (avaliações 2, 3, 4 e 5). Durante essa fase, que poderá durar até 24 meses, deverão ser realizadas avaliações, a cada 6 meses, para acompanhar o desenvolvimento/evolução do projeto para manutenção do mesmo na pré-incubadora.

Pós-Incubação

Período conhecido também como graduação do projeto, em que o modelo de negócio desenvolvido com apoio da pré-incubadora poderá promover o desenvolvimento econômico/social e a real difusão da inovação com a inserção de novos produtos e serviços no mercado.

Análise SWOT

Para o desenvolvimento da Pré-incubadora Tecnológica da FOB-USP, realizou-se a análise SWOT, ferramenta utilizada na administração, acrônimo de

\footnotetext{
${ }_{10}$ Apresentação direta e curta, com o objetivo de vender a ideia da sua startup para um possível investidor.
} 
Forças (Strengths), Fraquezas (Weaknesses), Oportunidades (Opportunities) e Ameaças (Threats), conforme pode ser observado no Quadro 4.

Quadro 4 - Análise SWOT para implantação da Pré-incubadora Tecnológica FOB-USP

\begin{tabular}{|c|c|c|}
\hline & FORÇAS & FRAQUEZAS \\
\hline \multirow[t]{2}{*}{ 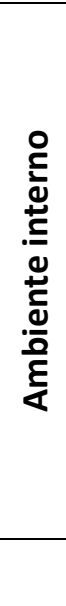 } & $\begin{array}{l}\text { - Referência na área da saúde } \\
\text { - Polo gerador de profissionais e conhecimento na } \\
\text { área da saúde } \\
\text { - Agência USP de inovação (patentes) } \\
\text { - Pesquisa intensa } \\
\text { - Internacionalização da USP } \\
\text { - Reconhecimento de entidades de pesquisa e } \\
\text { fomento } \\
\text { - Disponibilização de laboratórios para Pesquisa, } \\
\text { Desenvolvimento e Inovação (P, D \& I). } \\
\text { - Credibilidade junto à sociedade } \\
\text { - Conhecimento técnico na elaboração de projetos } \\
\text { de captação de recursos para inovação em } \\
\text { instituições de pesquisa e fomento. }\end{array}$ & $\begin{array}{l}\text { - Ausência de formação empreendedora no } \\
\text { contexto USP } \\
\text { - Falta de integração com o mercado/empresas } \\
\text { - Falta de integração com outras IES em Bauru } \\
\text { - Dificuldade para integrar diferentes esforços } \\
\text { para quebra de cultura instalada } \\
\text { - Escassez de recursos (atualmente) para pesquisa }\end{array}$ \\
\hline & OPORTUNIDADES & AMEAÇAS \\
\hline 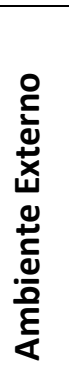 & $\begin{array}{l}\text { - Transformar projetos em soluções inovadoras para a } \\
\text { sociedade } \\
\text { - Polo de serviços em saúde (IES, hospitais, clínicas, etc.) } \\
\text { - Lei da inovação municipal } \\
\text { - Ambiente integrador em instalação com diferentes } \\
\text { atores (IES, órgãos públicos e privados, associações de } \\
\text { classe, etc.) } \\
\text { - Disponibilidade técnica de diferentes atores para apoio } \\
\text { ao projeto (IES, Sistema S, escolas técnicas, associações } \\
\text { de profissionais, etc.) } \\
\text { - Pioneirismo do projeto na área e na região }\end{array}$ & $\begin{array}{l}\text { - Políticas públicas distantes das necessidades de } \\
\text { mercado (empresas) } \\
\text { - Desarticulação de lideranças } \\
\text { - Falta de comportamento cooperativo e } \\
\text { empreendedor na sociedade } \\
\text { - Falta de recursos para investimento }\end{array}$ \\
\hline
\end{tabular}

Fonte: elaborado pela pesquisadora (2021)

Para aprofundar a análise realizada, optou-se por avaliar a implantação da Pré-incubadora Tecnológica FOB-USP com a utilização do quadro modelo de negócios ou "canvas" - Figura 4. O qual servirá como base para a reunião de requisitos para concretização desse importante projeto. 
Figura 4 - Quadro Modelo de Negócios da Pré-incubadora Tecnológica FOB-USP

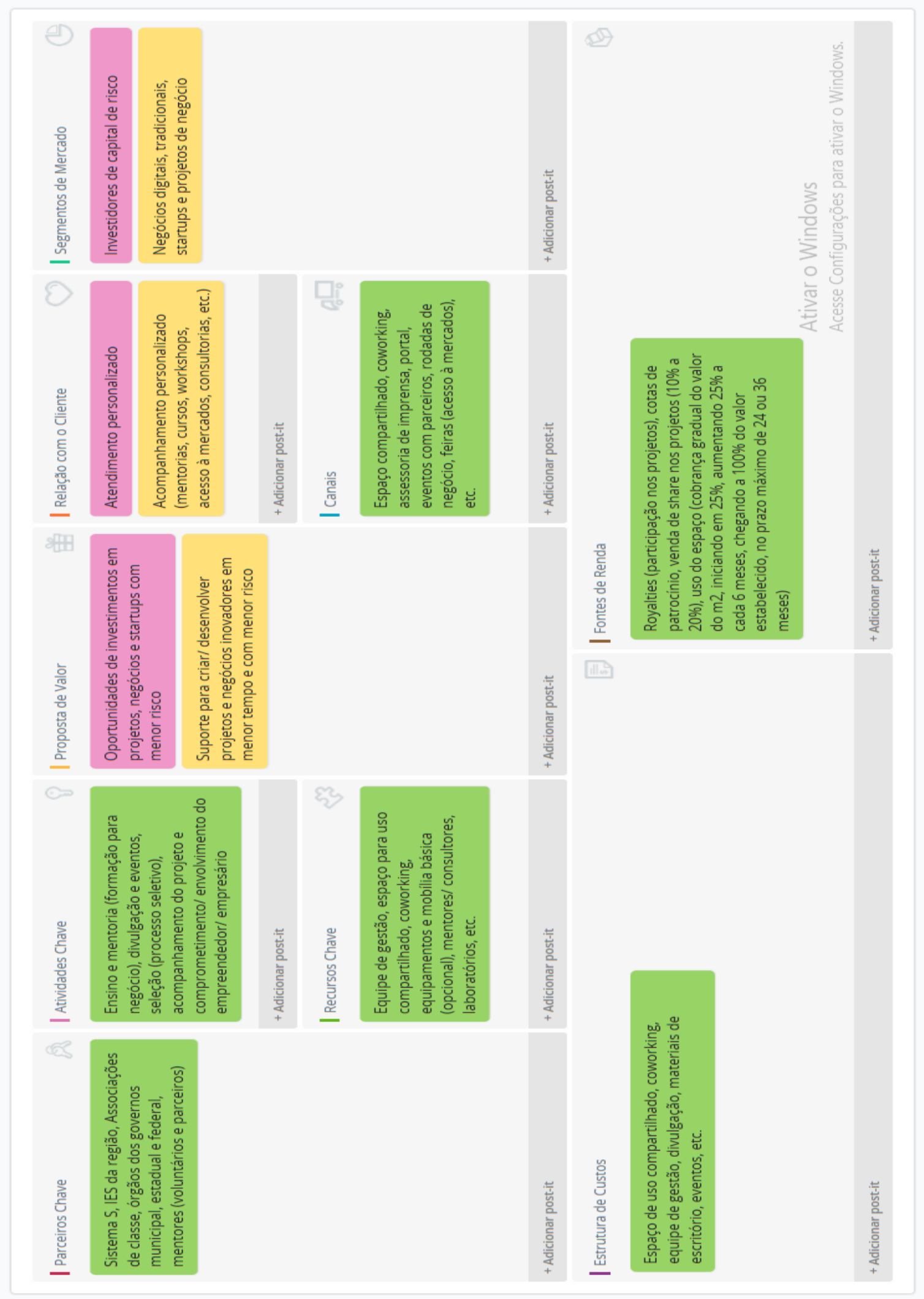

Fonte: elaborado pela pesquisadora (2021) 
Ainda, são relacionados a seguir, rol de Documentos Importantes para o funcionamento, manutenção e gestão da pré-incubadora:

a) Estatuto social da pré-incubadora Tecnológica da FOB - USP Estabelece a denominação, sede e prazo de duração da pré-incubadora, finalidades e áreas de apoio, estrutura organizacional (conselhos deliberativo/gestor, conselho consultivo, gestão do projeto, secretaria, conselho fiscal), composição de patrimônio e das receitas e regras para aferição do exercício financeiro.

b) Regimento interno - Estabelece o seu modelo de organização e operação (definindo modelo de receita, investimento e utilização dos espaços de uso exclusivo e compartilhado, composição dos conselhos, regras de pré-incubação e permanência no projeto).

c) Termo de cooperação - Estabelece condições, objetivos e responsabilidades resultante da cooperação entre parceiros e Pré-incubadora Tecnológica.

d) Contrato de uso compartilhado - Baseado no regimento interno da Préincubadora, trata dos direitos e deveres do projeto incubado (horário de funcionamento, regras gerais do espaço exclusivo e compartilhado, responsabilidades das partes, remuneração pelo espaço, etc.).

e) Modelo padrão de plano de negócios - Formulário padrão para submissão de projetos para pré-incubação que oferece ao empreendedor roteiro para demonstrar como se desenvolverá o projeto/negócio/oportunidade sob os contextos de mercado, operação e finanças.

A proposta apresentada nesse estudo, procurou contemplar todas as nuances observadas nas pesquisas realizadas (referencial teórico, pesquisa com as pré-incubadoras e seus respectivos resultados e análises e entrevista com profissional especialista do Sebrae) que possibilitou a consolidação dos pensamentos, observando as oportunidades e situações que apontavam pontos de atenção para oferecer uma proposta de implantação de pré-incubadora que carece de aprofundamento no aspecto econômico e financeiro, de acordo com as necessidades e demandas da instituição, bem como suas expectativas com relação ao potencial que pode ser oferecido com essa modalidade de projeto para a consolidação da FOB-USP como força propulsora do empreendedorismo, inovação e, por conseguinte, na sua contribuição para o desenvolvimento econômico local e regional. 



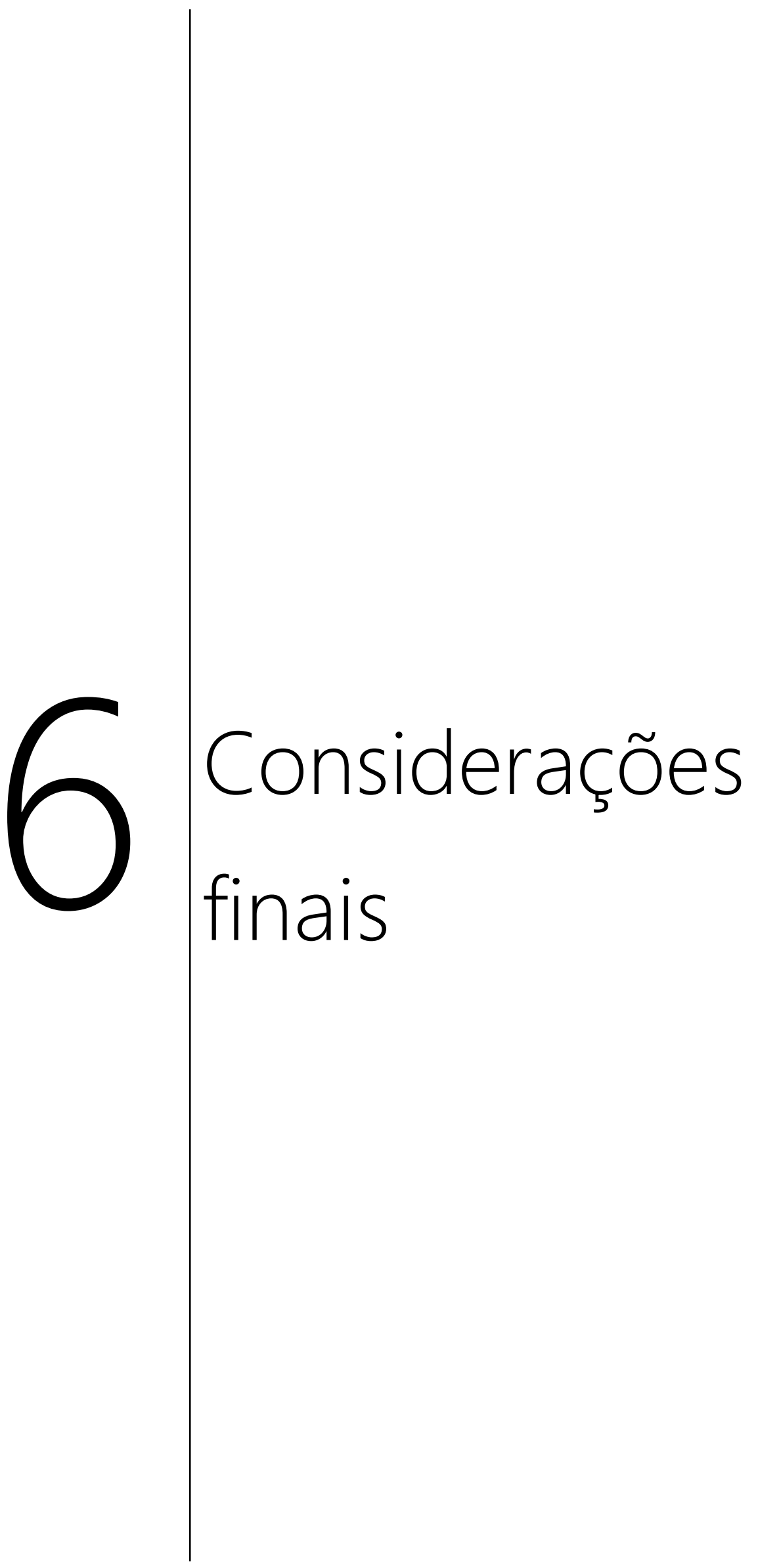





\section{CONSIDERAÇÕES FINAIS}

O objetivo geral dessa dissertação foi apresentar um estudo para a implantação de um modelo de pré-incubadora de empresas na área da saúde para a Faculdade de Odontologia de Bauru - FOB-USP, o qual foi amplamente pesquisado em referenciais teóricos nacionais e internacionais, na pesquisa realizada com as préincubadoras que participaram do estudo e ainda com a entrevista realizada com profissional especialista do Sebrae.

Esse minucioso estudo permitiu apresentar o modelo proposto para a implantação da pré-incubadora de empresas e que foi detalhado no capítulo anterior.

Com relação aos objetivos específicos, buscou-se explorar junto à literatura nacional e internacional e discorrer sobre os princípios teóricos, abordagens e modelos de pré-incubadoras de empresas, inovação, competitividade, desenvolvimento econômico e social, empreendedorismo, ecossistemas de inovação e pesquisa científica. Ainda, considerando a pesquisa realizada com as préincubadoras, pode-se realizar um levantamento e avaliar casos de sucesso e insucesso de pré-incubadoras universitárias. Além disso, a pesquisa permitiu identificar modelos de pré-incubadoras que possam servir de referência para elaboração de modelo adequado à realidade da Faculdade de Odontologia de Bauru - FOB-USP.

Essa dissertação ainda permitiu realizar um levantamento sobre as condições para conversão de pesquisa científica em projetos e empreendimentos apoiados por pré-incubadoras e identificar os desafios e oportunidades com a implantação de uma pré-incubadora na área da saúde.

Com a proposta de implantação da pré-incubadora de projetos, será possível promover a interação de pesquisadores de áreas multidisciplinares, laboratórios de pesquisas e programas de pós-graduação com o setor produtivo, no estudo e criação de produtos/processos inovadores na saúde, em especial, nas áreas de abrangência da graduação e pós-graduação da Faculdade de Odontologia de Bauru - FOB, da Universidade de São Paulo, no município de Bauru.

A análise dos impactos financeiros advindos da implantação ofertada nesse estudo e sua respectiva aplicação deve ser considerada por esta instituição de ensino superior porque pode proporcionar importante contribuição ao demonstrar a viabilidade e a importância da transformação da pesquisa científica ao ser inserida no 
mercado, convertendo seus projetos em inovação, transformando ideias em negócios, gerando emprego e renda e com enorme potencial para colaborar com 0 desenvolvimento econômico e social local e regional.

Diante do exposto, espera-se que a pesquisa realizada, com suas inferências, reflexões e tratamentos empreendidos possam ser objeto de aplicação em outros estudos, considerando a atualidade dos temas abordados e a sua importância para a ciência, o empreendedorismo, a inovação, o ecossistema de inovação, o desenvolvimento econômico local e regional, bem como, fortalecer ainda mais a imagem dessa respeitada universidade, uma vez que essas ações também podem contribuir para a melhoria das condições dos discentes, docentes, pesquisadores, empreendedores, enfim, todos os atores que podem ser beneficiados e impactados por esse importante projeto que, por sua vez, tem grande chance de promover a melhoria das condições do país ao propor modelos de interação que permitem alavancar os negócios a se tornarem menos arriscados, com melhores taxas de sobrevivência, com alto grau de inovação, tornando-os sustentáveis em longo prazo e por poderem contribuir com seus impostos, gerar empregos e desenvolver produtos e serviços para que se promova um círculo virtuoso de desenvolvimento social e econômico, em especial a conversão da pesquisa em possibilidades de negócio. 
Referências 



\section{REFERÊNCIAS}

Associação Brasileira de Startups (ABStartups). Incubadoras de empresas: o que é e para que serve. 2020. Disponível em: <https://abstartups.com.br/incubadora-deempresas-o-que-e-e-para-que-serve/>. Acesso em: 21 out. 2019.

Associação Nacional de Entidades Promotoras de Empreendimentos Inovadores (Anprotec). Mapeamento dos mecanismos de geração de Empreendimentos Inovadores no Brasil / Anprotec; textos: Claudia Pavani... [et.al.]. - Brasília: Anprotec, 2019.

Associação Nacional de Pesquisa e Desenvolvimento das Empresas Inovadoras (ANPEI). Ecossistemas de inovação. 2020. Disponível em: <https://anpei.org.br/oque-sao-ecossistemas-de-inovacao-e-qual-sua-

importancia/\#: :text=Um\%20ecossistema\%20de\%20inova\%C3\%A7\%C3\%A30\%20n ada,associa\%C3\%A7\%C3\%B5es\%20s\%C3\%A3o\%20exemplo\%20desses\%20ecos sistemas. >. Acesso em: 20 out. 2019.

BRASIL. Presidência da República. Casa Civil. Lei 10.973/2004: Dispõe sobre incentivos à inovação e à pesquisa científica e tecnológica no ambiente produtivo. Disponível em: < http://www.planalto.gov.br/ccivil_03/_Ato20042006/2004/Lei/L10.973.htm> Acesso em: 06 fev. 2020.

BRESOLIN T. et al. Incubadora Tecnológica de Caxias do Sul: Inovação Tecnológica sob a Perspectiva da Hélice Tríplice. In: XIII Mostra de Iniciação Científica, Pós-graduação, Pesquisa e Extensão. 2013.

CARBONE, P. P et al. Gestão por competências e gestão do conhecimento. Rio de Janeiro: Editora FGV, 2006.

CHIARINI, T.; VIEIRA, K. P. Universidades nos sistemas de inovação: produção de pesquisa científica nas universidades federais do nordeste do Brasil. Revista

Economia \& Tecnologia (RET). V. 8, n. 1, p. 137-160, Jan/Mar 2012. Disponível em:

$<$ https://www.researchgate.net/publication/268188953_Universidades_nos_sistemas _de_inovacao_producao_de_pesquisa_cientifica_nas_universidades_federais_do_n ordeste_do_Brasil >. Acesso em: 10 fev. 2020.

CHIAVENATO, I. Empreendedorismo. Dando asas ao espírito empreendedor. 4.ed. São Paulo: Manole, 2012.

CNI. Financiamento à inovação. Confederação Nacional da Indústria, Serviço Social da Indústria, Serviço Nacional de Aprendizagem Industrial, Instituto Euvaldo Lodi - Brasília: CNI, 2016

DORNELAS, J. C. A. Empreendedorismo: transformando ideias em negócios. 2. ed. Rio de Janeiro: Elsevier, 2005.

ETZKOWITZ, H. Innovation in innovation: The triple helix of University-IndustryGovernment relations. Social science information, v. 42, n. 3, p. 293-337, 2003. 
Disponível em: < http://ssi.sagepub.com/content/42/3/293.short> Acesso em: 15 de jan. de 2020.

FERREIRA, A. B. H. Minidicionário Aurélio da Língua Portuguesa . 3. ed. Rio de Janeiro: Nova Fronteira, 1993.

FREEMAN, C. Technology policy and economic performance. Londres:

PinterPublishers London and New York, 1987.

FROIS, E.; PARREIRAS, F. Análise do processo de inovação tecnológica em uma incubadora universitária sob a perspectiva do modelo de Cambridge. UFMG, 2004. Disponível em:

$<$ http://www.fernando.parreiras.nom.br/publicacoes/incubadoras.

pdf>. Acesso em 7 fev. 2020.

GOBBO JR., J.A.; VASCONCELLOS, M. A. Proposal of a framework for the analysis of the innovation process in networks. In: The 3rd World Conference on Production and Operations Management, 2008, Tóquio. Proceedings of The 3rd World Conference on Production and Operations Management, 2008.

GOERK, C. Incubadoras Universitárias: sua contribuição aos empreendimentos de economia popular solidária. Sociedade em Debate, v. 15, n. 2, p. 77-89, 2009. Disponível em:< http://www.rle.ucpel.tche.br/index.php/rsd/article/view/354/311> Acesso em 07 de jan de 2020.

GREDEL, D.; KRAMER, M.; BEND, B. Patent-based investment funds as innovation intermediaries for SMEs: In-depth analysis of reciprocal interactions, motives and fallacies. Technovation, v. 32, n. 9, p. 536-549, 2012. Disponível em: < http://www.sciencedirect.com/science/article/pii/S0166497211001337> Acesso em: 14 de jun de 2016.

Instituto de Pesquisa Econômica Aplicada (IPEA). Desafios do desenvolvimento. 2020. Disponível em:

$<$ https://www.ipea.gov.br/desafios/index.php?option=com_content\&view=article\&id=7 36:rep>. Acesso em: 21 out. 2019.

Instituto Nacional de Telecomunicações (INATEL). Pré-incubadoras. 2020. Disponível em: <https://www.inatel.br/empreendedorismo/pre-incubadora>. Acesso em: 21 out. 2019.

JISHNU, V.; GILHOTRA, R. M.; MISHRA, D. N. Pharmacy education in India: Strategies for a better future. Journal of Young Pharmacists, v. 3, n. 4, p. 334-342, 2011.

MATOS, C.; TELLES, A. Empreendedor Viável. Rio de Janeiro: Leya, 2013.

MEDEIROS, J.A, MEDEIROS, L.A, MARTINS, T., PERILO, S. Pólos, parques e incubadoras - A busca da modernização e competitividade. CNPq, SCT/PR, IBICT, SENAI. Brasília, 1992. 
OECD (Organisation for Economic Co-operation and Development). Manual de Oslo: proposta de diretrizes para coleta e interpretação de dados sobre inovação tecnológica. Versão FINEP, 2004.

OLIVEIRA, A. S. de. Análise das interações universidade-empresa em empresas incubadas e graduadas numa incubadora universitária de empresas. 2010. $196 \mathrm{f}$. Dissertação (Mestrado) - Curso de Administração, Universidade Federal do Rio Grande do Sul, Porto Alegre, 2010. Disponível em: <http://www.lume.ufrgs.br/bitstream/handle/10183/26008/000756447.pdf?sequence=1> Acesso em: 13 jan. 2020.

OLIVEIRA, G. S. Gestão da informação e do conhecimento como estratégia de negócios . Simpósio de Engenharia de Produção, XII. 2005. Anais... Bauru, SP: SIMPEP, 2005. Disponível em: http://www.simpep.feb.unesp.br/Anais_XII/09.html . Acesso em: 18 jan. 2019.

OMS (Organização Mundial da Saúde). Relatório mundial de envelhecimento e saúde. Geneva: OMS; 2015. Disponível em:<https://sbgg.org.br//wpcontent/uploads/2015/10/OMS-ENVELHECIMENTO-2015-port.pdf>. Acesso em 15 fev. 2020.

PAULA, J. Desenvolvimento \& Gestão compartilhada . Agência de educação para o desenvolvimento e Gerente da unidade de desenvolvimento local do SEBRAE Nacional, 2006.

PAPAIOANNOU, T.; WIELD, D; CHATAWAY, J. Knowledge ecologies and ecosystems? An empirically grounded reflection on recent developments in innovation systems theory. Environment and Planning C: Government and Policy, v. 27, n. 2, p. 319-339, 2009.

PORTER, M.E. Estratégia competitiva: técnicas para análise de indústrias e da concorrência. 2. ed. Rio de Janeiro: Elsevier, 2004.

RADEMAKERS, M. F. L. Corporate universities: driving force of knowledge innovation. Journal of Workplace Learning. v. 17, n. 1/2, p. 130-136, 2005.

SANTOS, A. B. A.; FAZION, C. B.; MEROE, G. P. S. Inovação: um estudo sobre a evolução do conceito de Schumpeter. Caderno de Administração, v. 5, n. 1, 2011.

SCHUMPETER, J. A. Business cycles: a theoretical, historical and statistical analysis of the capitalist process. New York: Mcgraw-Hill, 1939.

Capitalismo, socialismo e democracia (S. G. de Paula, Trad.).

Rio de Janeiro: Zahar, 1942.

SEBRAE. O que é ser empreendedor . Disponível em:http://www.sebrae.com.br/sites/PortalSebrae/bis/o-que-e-serempreendedor, ad17080a3e107410VgnVCM1000003b74010aRCRD. Acesso em 17 fev. 2019. 
Panorama dos pequenos negócios. São Paulo: Sebrae/SP, 2019.

Disponível em: <

http://www.sebrae.com.br/Sebrae/Portal\%20Sebrae/UFs/SP/Pesquisas/Panorama\%

20dos\%20Pequenos\%20Negocios\%202019.pdf>. Acesso em: 25 jan. 2020.

SMILOR, R. W., DAVID V. G.; GLENN B. D. Spin-out Companies: Technology Start-ups from UT-Austin, Journal of Business Venturing, Elsevier, v.5, n. 1, p. 6376.1990.

SOTO, E. Comportamento organizacional: o impacto das emoções. São Paulo: Pioneira Thompson Learning, 2005.

SOUZA, E. C. L. de; SOUZA, C. C. L. de; ASSIS, S. A. G. e ZERBINI, Thais.

Métodos e Técnicas de Ensino e Recursos Didáticos para o Ensino do Empreendedorismo em IES Brasileiras . In: Encontro da ANPAD, 28, 2004, Curitiba/PR. Anais ... Curitiba: ANPAD, 2004. CD ROM.

VIEIRA, E. T.; SANTOS, M. J. Desenvolvimento Econômico Regional - Uma revisão histórica e teórica . In: Revista Brasileira de Gestão e Desenvolvimento Regional. v. 8, n. 2, 2012.

WEF. Global Competitiveness Report. World Economic Forum, 2015. Disponível em: < http://www3.weforum.org/docs/gcr/2015-

2016/Global_Competitiveness_Report_2015-2016.pdf>. Acesso em: 23 fev. 2020.

Global Competitiveness Report. World Economic Forum, 2017. Disponível em: <http://www3.weforum.org/docs/GCR2016-

2017/05FullReport/TheGlobalCompetitivenessReport2016-2017_FINAL.pdf>. Acesso em: 23 fev. 2020.

Global Competitiveness Report. World Economic Forum, 2018. Disponível em: <http://www3.weforum.org/docs/GCR2017-

2018/05FullReport/TheGlobalCompetitivenessReport2017\%E2\%80\%932018.pdf>. Acesso em: 23 fev. 2020.

em:

Global Competitiveness Report. World Economic Forum, 2019. Disponível

<http://www3.weforum.org/docs/WEF_TheGlobalCompetitivenessReport2019.pdf>. Acesso em: 28 set. 2020.

WESSNER, C. W. et al. (Ed.). Innovation policies for the 21st century: report of a symposium. Washington: National Academies Press, 2007. 